

\section{THE UNIVERSITY}

\section{OF ILLINOIS}

$$
\begin{aligned}
& \text { LIBRARY } \\
& 630.7 \\
& \text { I } 6.6 \\
& n 0.400 .08 \\
& \text { cop. } 2
\end{aligned}
$$


NOE GIBCULATINE

EHECK FOR UVERUIND CIRCULATING COPY 
. 



\section{Production and}

\section{MARKETING of REDTOP}

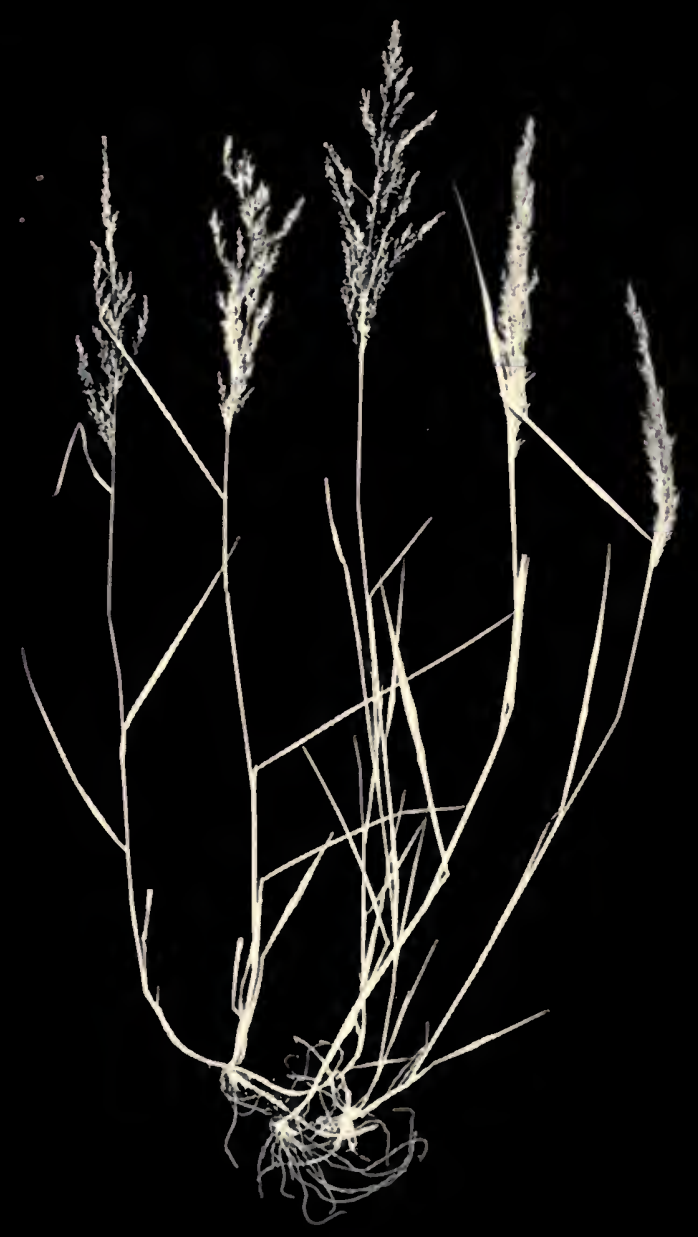

UNIVERSITY OF ILLINOIS

AGRICULTURAL EXPERIMENT STATION BULLETIN 404 



\title{
Production and Marketing
}

\section{of Redtop}

Including a Study of the Place of Redtop in the Organization of Southern Illinois Farms

\author{
By \\ IV. L. Burlison \\ C. L. Stewart \\ R. C. Ross \\ and \\ O. L. IVhaliN
}




\section{CONTENTS}

1N'TKOUUCTION

CULTURAI, IRACTICFS FOLLOWED IN GROWING AND

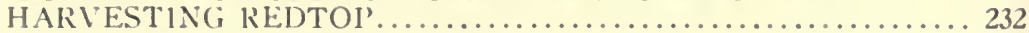

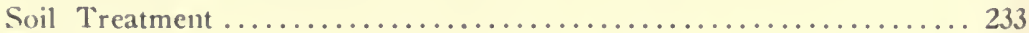

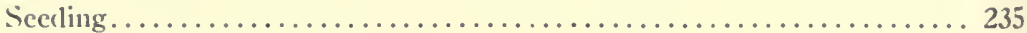

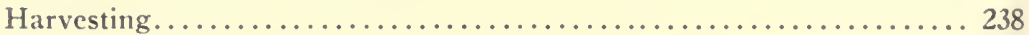

PRODUCTION OF REDTOP IN ILLINOIS ................. 241

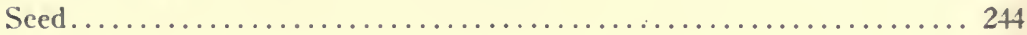

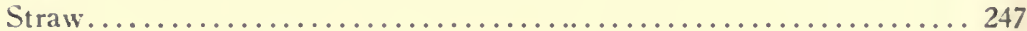

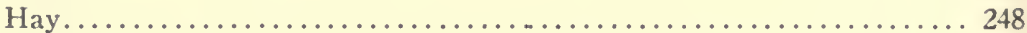

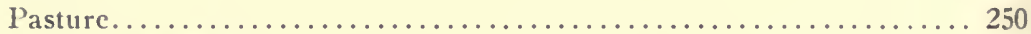

DISPOSITION MADE OF THE REDTOP CROP IN ILLINOIS...... 251 COMPETITION BETWEEN REDTOP AND OTHER GRASS SEEDS 255 IIETHODS AND PROBLEMS OF MARKETING REDTOP' SEEI)... 257

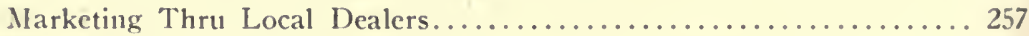

Marketing Thru the Egyptian Seed Growers' Exchange and the

Redtop Growers' Warchouse Association................... 26!

Marketing by Wholesale Dealers........................ 262

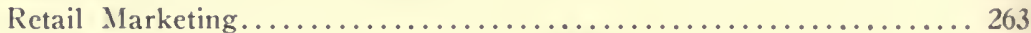

Recent Efforts to Stabilize Redtop Seed Marketing.............. 264

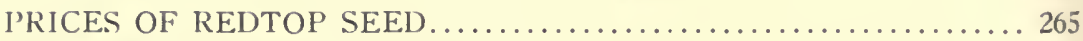

FARM MANAGEMENT ASPECTS OF REDTOP PRODUCTION

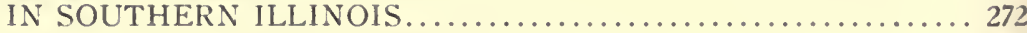

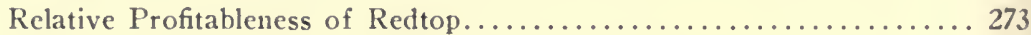

Extent to Which Period of Study Was Normal................ 273

Organization of Redtop Farms in the Redtop District............. 277

Redtop in the Cropping System............................ 279

Competition of Redtop With Other Crops................. 281

Business Analysis of Account-Kecping Farms in the Redtop District... 284

How Redtop Has Been Used on Selected Farms............... 288

EFFECT OF CASH-OUTLAY REQUIREMENTS ON USE

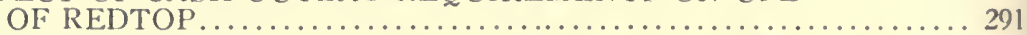

PLACE OF REDTOP IN FUTURE ADIUSTMENTS OF

SOUTHERN ILLINOIS AGRICULTURE .................. 292

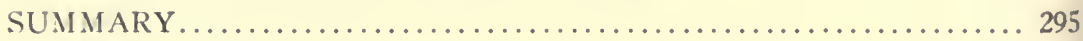

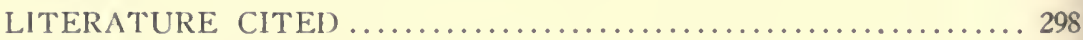

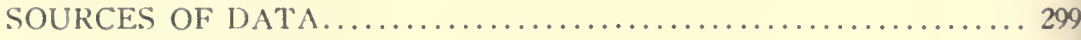

Urbana, Illinois

Publications in the Bulletin series report the results of investigations made by or sponsored by the Experiment Station 


\section{Production and Marketing of Redtop}

Including a Study of the Place of Redtop in the Organization of Southern Illinois Farms

By W. L. Burlison, C. L. Stewart, R. C. Ross, and O. L. Whalin

$\mathbb{R}^{1}$

EDTOP occupies an important place in meadows and pastures in the northern humid region of the United States, particularly east of the Mississippi river, and in the more mountainous portions of the humid regions of the Southeast. It is the second most important pasture grass in the United States, ${ }^{7 *}$ ranking next to Kentucky bluegrass. About 85 percent $^{6 *}$ of the world's supply of redtop seed and 95 percent of the total redtop seed in the United States is produced in a dozen counties in southern Illinois, and has been produced there since about $1875 .{ }^{*}$ A limited amount of redtop seed is produced in Iowa and Missouri as a volunteer crop with timothy.

Redtop, the most important of the grasses belonging to the genus Agrostis, $\mathrm{b}$ is a perennial of the bent-grass group, having a creeping underground habit of growth which makes a coarse, loose sward. If grown isolated, a redtop plant makes tufts 1 to 3 feet in diameter which vary from about 30 to 40 inches in height. The vigorous rootstalks are shallow and generally 2 to 6 inches in length. Redtop matures about the same time as timothy. It is unquestionably native to Europe and not to America, ${ }^{8 *}$ despite the claims of some early botanists and others that it is native to Illinois..$^{5 *}$

The concentration of redtop seed production in the southern part of Illinois has been due to a combination of economic factors, favorable climate, and soils not so well adlapted to other crops. Most of the seed that is now being produced in the Illinois redtop district is grown on gray soils with impervious noncalcareous subsoil (Fig. 3). These lands are very poorly drained, cannot be successfully tiled, are very acid, and have areas called "slick spots." $11 *$ Owing to drainage conditions, it is very difficult to utilize more than a small percentage of such farms in cultivated crops that require spring seed-bed preparation. Thus a crop like redtop, that once seeded down grows for a number of years with little care other than that involved in harvesting the

*IV. L. Burlison, Department of Agronomy; C. I. Stewart and R. C. Ross, Department of Agricultural Economics; and O. L. W HALiN, formerly in Department of Agricultural Finomics.

'Agrostis alba L. or Agrostis palustris Hudson.

"These numbers refer to literature citations on page 298. 
seed, fits well into the usual farming plan. It is one of the chief money crops of southern Illinois.

The principal uses of redtop are: (1) as a wet-land or sour-land hay crop; (2) as a part of pasture mixtures, especially on wet, sour,

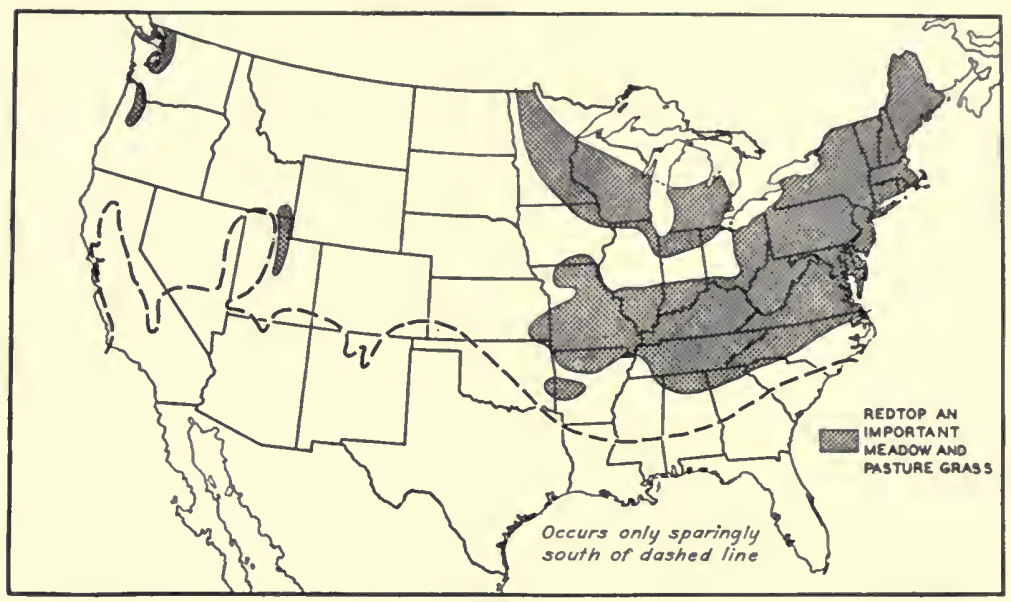

Fig. 1.-Distribution of Redtop in the United States

Redtop occupies an important place in many pastures and meadows of the northern humid region and the more mountainous portions of the southeastern humid region, particularly where the land is not well drained.

and poor land and in New England where the English idea of seed mixtures for "top" and "bottom" grasses is well established; (3) as a part of lawn and golf-course mixtures; (4) as a soil binder; and (5) as an ingredient in seed mixtures for hay to be used on the farm.

\section{CULTURAL PRACTICES FOLLOWED IN GROWING AND HARVESTING REDTOP}

No other cultivated grass will grow under so wide a range of conditions of soil and climate as will redtop. It succeeds well over most

Note.-Redtop was introduced at an early date into the American colonies, probably in grass-seed mixtures. The agricultural value of this grass was well recognized in New Jersey by $1804^{\text {s* }}$ the seed having been brought there from New England. The crop had been introduced into southern Illinois from the Ohio valley by the early fifties, where it was used mainly for hay and pasture." The first lot of redtop seed from southern Illinois was marketed in Cincinnati in the late fifties." Contact was made with markets in New York in 1867. 
of the United States except in the drier regions and in the extreme south. Redtop is at least the equal of timothy in resistance to cold, and withstands summer heat much better, particularly on the poor soils

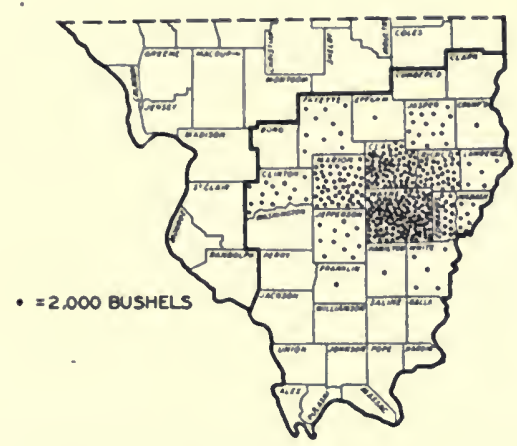

Fig. 2.-Pronuction of Rentop and Other Grass Seed 1. 32 SOUthern Illinors Counties, 1929

Redtop seed production (which makes up the largest part of "other grass scel," Census classification) is highly localized in Illinois, being centered in the countics of Marion, Wayne, Clay, Richland, and Edwards. The adjoining counties of Jasper and Fayette on the north, Clinton on the west, Jefferson and White on the south, and Wabash and Lawrence on the east produce considerable seed in the portions of these countics lying adjacent to the five counties of greatest concentration.

where it is most commonly grown. Redtop thrives best on moist or wet soils, altho it has high drouth endurance. It grows on soils deficient in lime where most other grasses fail, but does best on loam soils, including clay loams.

\section{Soil Treatment}

The effect of soil treatment on the yield of redtop for seed and hay has been studied in work conducted on the Newton and Odin experiment fields in the main redtop district of Illinois (Table 1).

The use of organic manures and lime, considered on these soils as basic treatment, gave yields considerably higher than the average for the redtop area. At Odin each addition in soil treatment resulted in an increased yield of hay but not always in an increased seed yield. At Newton rock phosphate gave increased yields of both seed and hay when added to the basic treatment. Increased amounts of limestone gave increased seed yields over the average yields on the treated check plots. 


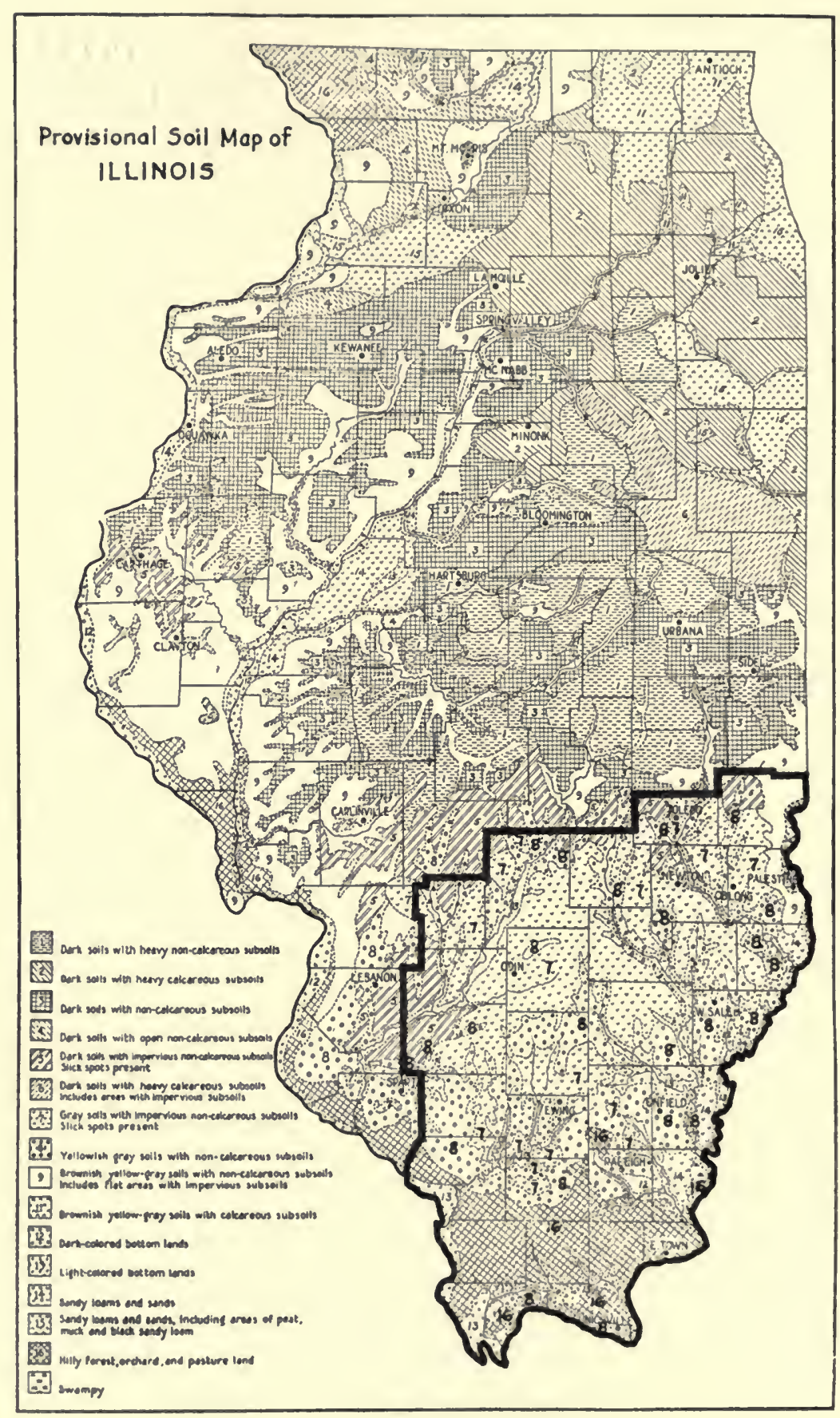

Fig. 3.-Soils in the Redtop District of Southern Illinois, 1929 
Table 1.-Effect of Soll Treatment on Yield of Redtop Seed and Hay, Newton and Odin Soll EXPERIMENT Fieldsa

(Pounds per acre)

\begin{tabular}{|c|c|c|c|c|c|c|c|}
\hline \multicolumn{3}{|c|}{ Odin field } & \multicolumn{3}{|c|}{ Newton field } & \multicolumn{2}{|c|}{ Newton field, lime series } \\
\hline \multirow[t]{2}{*}{ Treatment ${ }^{b}$} & \multicolumn{2}{|c|}{1931 yields } & \multirow[t]{2}{*}{ Treatment } & \multicolumn{2}{|c|}{$\begin{array}{l}\text { Average of } \\
1928,1929, \\
1932 \text { yields }\end{array}$} & \multirow[t]{2}{*}{ Treatment } & $\begin{array}{c}1929-30 \\
\text { yields }\end{array}$ \\
\hline & Seed & Hay & & Seed & Hay & & Seed \\
\hline 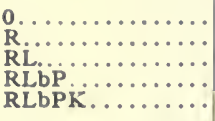 & $\begin{array}{l}60 \\
90 \\
78 \\
99 \\
60\end{array}$ & $\begin{array}{ll} & 940 \\
1 & 400 \\
1 & 890 \\
2 & 240 \\
3 & 230\end{array}$ & 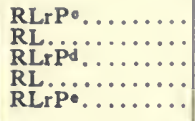 & $\begin{array}{l}89 \\
75 \\
80 \\
67 \\
84\end{array}$ & $\begin{array}{ll}1 & 660 \\
1 & 280 \\
1 & 420 \\
1 & 340 \\
1 & 380\end{array}$ & $\begin{array}{l}\operatorname{RrPK}, \ldots \ldots \\
\operatorname{RrPK}, \mathrm{L} 3 \text { tons .... } \\
\operatorname{RrPK}, \mathbf{L} 6 \text { tons... } \\
\operatorname{RrPK}, \mathrm{L} 12 \text { tons... }\end{array}$ & $\begin{array}{r}53 \\
86 \\
118 \\
96\end{array}$ \\
\hline
\end{tabular}

- Newton is in Jasper county; Odin in Marion county, Illinois.

bey to abbreviations:

$0=$ untreated land, or check plots

$\mathbf{M}=$ manure (animal)

$\mathbf{R}=$ residues (from crops, and including legumes used as green manure)

$\mathrm{L}=$ limestone

$\mathrm{bP}=$ ateamed bone meal

$\mathrm{rP}=$ rock phosphate

$\mathbf{K}=$ potassium (sulfate at Odin, kainit at Newton) an acre.

Phosphorus application sufficient to bring phosphorus content of surface soil to 2,000 pounds

d200 pounds of rock phosphate an acre a year.

-400 pounds of rock phosphate an acre a year.

\section{Seeding}

Redtop gives best results when planted on a well-prepared, compact seed bed, because the seeds are small and the plants delicate when young.

Redtop is usually sown broadcast. To obtain a stand ordinarily requires from 8 to 15 pounds of seed an acre, with an average of about 10 pounds. $^{3 *}$ The amount of redtop sown at any one time depends upon (1) whether the seeding is new or supplementary; (2) whether the seed is thresher-run or recleaned; and (3) whether redtop is seeded alone or with other grasses. The amount of recleaned redtop seed actually used for seeding at any one time probably averages not more than 4 pounds an acre and is seldom as high as 6 pounds.

Field-grass mixtures in which redtop plays a part are usually applied in amounts ranging from 10 to 20 pounds an acre. The amount of redtop in such mixtures is a tenth to a half of the total weight, redtop being used in the higher proportions on wet or poorly drained soils and in the smaller proportions on good, well-drained soils. ${ }^{14 *}$

The time of seeding redtop varies somewhat with the cropping system, tho it is usually seeded in the fall. If seeded after oats or soybeans, the seed bed may be prepared by thoro disking alone. Seed- 


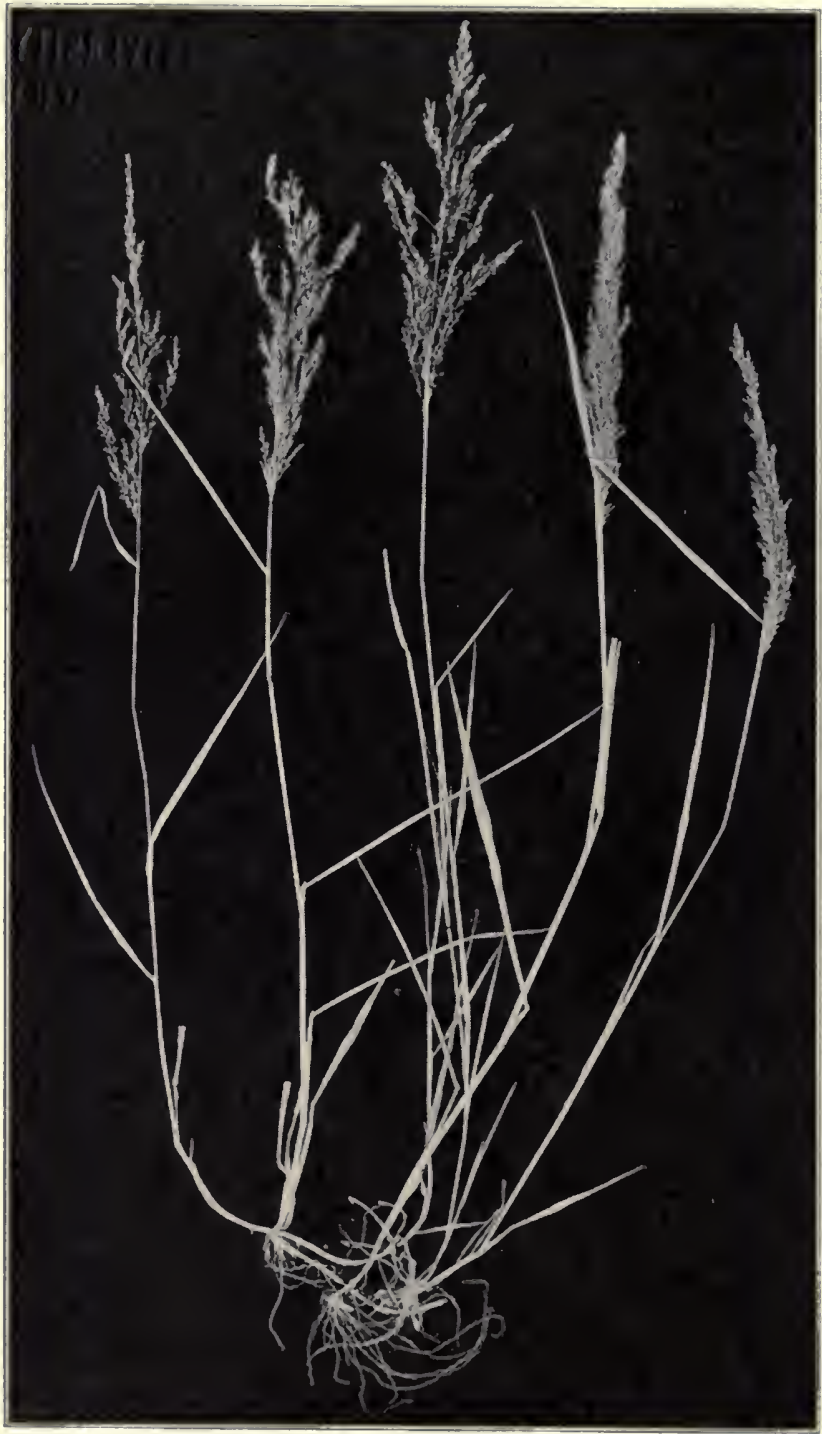

Fig. 4.-A Rentop Plant

Redtop is a perennial grass, growing 30 to 40 inches in height, with short, vigorous rootstalks. When redtop is kept closely clipped, the leaves become fine and a good turf results. If there is a thin stand, the plant becomes coarse and the leaves broad. The blades vary from 3 to 7 inches in length and the panicles from 3 to 11 inches. 
ing redtop in the spring on winter wheat land is sometimes practiced (Table 2).

The superiority of fall seeding over spring seeding in general is indicated by the data in Table 3 . No perceptible difference in yield

Table 2.-Indicated Preferences of Reporting Growers for Specified Crops to Precede and to Follow Redtop; Data Obtained From 14 SOUTHERN ILlinOIS COUNTIES ${ }^{a}$

\begin{tabular}{|c|c|c|c|c|c|c|c|c|c|c|c|}
\hline \multirow{2}{*}{ County } & \multirow{2}{*}{$\begin{array}{l}\text { Number } \\
\text { of farms } \\
\text { reported }\end{array}$} & \multicolumn{2}{|c|}{ Corn } & \multicolumn{2}{|c|}{ Oats } & \multicolumn{2}{|c|}{ Wheat } & \multicolumn{2}{|c|}{ Soybeans } & \multicolumn{2}{|c|}{ Cowpeas } \\
\hline & & Before & After & Before & After & Before & After & Before & After & Before & After \\
\hline $\begin{array}{l}\text { Clay............ } \\
\text { Clinton ........ } \\
\text { Cumberland .... } \\
\text { Edwards....... } \\
\text { Effingham.... }\end{array}$ & $\begin{array}{r}18 \\
2 \\
1 \\
6 \\
1\end{array}$ & $\begin{array}{c}4 \\
\cdots \\
2 \\
0\end{array}$ & $\begin{array}{c}17 \\
\cdots \cdots \\
\cdots \\
0\end{array}$ & $\begin{array}{c}6 \\
\cdots \\
0 \\
0\end{array}$ & $\begin{array}{c}0 \\
\cdots \\
\cdots \\
0 \\
0\end{array}$ & $\begin{array}{c}4 \\
\cdots \\
\cdots \\
0\end{array}$ & $\begin{array}{c}1 \\
\cdots \cdots \\
i \\
0\end{array}$ & $\begin{array}{c}5 \\
\cdots \\
\cdots \\
1\end{array}$ & $\begin{array}{c}3 \\
\cdots \\
\cdots \\
1 \\
0\end{array}$ & $\begin{array}{c}1 \\
\cdots \cdots \\
i \\
0\end{array}$ & $\begin{array}{c}1 \\
\cdots \cdots \\
2 \\
2 \\
0\end{array}$ \\
\hline $\begin{array}{l}\text { Fayette......... } \\
\text { Hamilton...... } \\
\text { Jasper........ } \\
\text { Jefferson. . . } \\
\text { Marion...... }\end{array}$ & $\begin{array}{r}4 \\
5 \\
11 \\
8 \\
12\end{array}$ & $\begin{array}{l}0 \\
1 \\
4 \\
0 \\
3\end{array}$ & $\begin{array}{l}3 \\
3 \\
8 \\
6 \\
8\end{array}$ & $\begin{array}{l}1 \\
0 \\
4 \\
0 \\
4\end{array}$ & $\begin{array}{l}0 \\
0 \\
1 \\
0 \\
1\end{array}$ & $\begin{array}{l}2 \\
2 \\
3 \\
1 \\
6\end{array}$ & $\begin{array}{l}0 \\
1 \\
0 \\
0 \\
0\end{array}$ & $\begin{array}{l}\mathbf{0} \\
0 \\
\mathbf{5} \\
1 \\
3\end{array}$ & $\begin{array}{l}\mathbf{0} \\
0 \\
3 \\
0 \\
2\end{array}$ & $\begin{array}{l}0 \\
1 \\
0 \\
4 \\
1\end{array}$ & $\begin{array}{l}0 \\
2 \\
0 \\
1 \\
0\end{array}$ \\
\hline $\begin{array}{l}\text { Perry .......... } \\
\text { Richland....... } \\
\text { Wayne........ } \\
\text { White........ } \\
\text { (Not stated).... }\end{array}$ & $\begin{array}{r}1 \\
15 \\
15 \\
4 \\
3\end{array}$ & $\begin{array}{l}0 \\
3 \\
4 \\
0 \\
0\end{array}$ & $\begin{array}{r}1 \\
14 \\
13 \\
3 \\
2\end{array}$ & $\begin{array}{l}0 \\
4 \\
3 \\
0 \\
1\end{array}$ & $\begin{array}{l}\mathbf{0} \\
0 \\
0 \\
0 \\
0\end{array}$ & $\begin{array}{l}0 \\
7 \\
1 \\
1 \\
2\end{array}$ & $\begin{array}{l}0 \\
0 \\
1 \\
0 \\
0\end{array}$ & $\begin{array}{l}0 \\
5 \\
5 \\
0 \\
0\end{array}$ & $\begin{array}{l}0 \\
3 \\
3 \\
0 \\
3\end{array}$ & $\begin{array}{l}1 \\
0 \\
4 \\
2 \\
0\end{array}$ & $\begin{array}{l}1 \\
0 \\
1 \\
0 \\
1\end{array}$ \\
\hline Total for area... & 106 & 21 & 82 & 23 & 2 & 31 & 4 & 25 & 18 & 15 & 9 \\
\hline
\end{tabular}

-Other crops mentioned once to be produced before redtop were legumes, hay, rye, and grain; and mentioned once to follow redtop were sweet clover, kafir corn, and sunflower.

Table 3.-Influence of Date of Seeding on Yields of Redtop SEEd AND HAY, NEwTON Field

(Pounds per acre)

\begin{tabular}{|c|c|c|c|c|}
\hline \multirow{2}{*}{ Season harvested } & \multicolumn{2}{|c|}{ Seeded in October, 1926} & \multicolumn{2}{|c|}{ Seeded in February, 1927} \\
\hline & Seed & Hay & Seed & Hay \\
\hline $\begin{array}{l}1927 \ldots \ldots \ldots \ldots \ldots \ldots \ldots \ldots \ldots \ldots \ldots \ldots \ldots \\
1928 \ldots \ldots \ldots \ldots \ldots \ldots\end{array}$ & $\begin{array}{l}42 \\
69\end{array}$ & $\begin{array}{r}380 \\
2 \quad 220\end{array}$ & $\begin{array}{l}30 \\
49\end{array}$ & $2 \begin{array}{l}300 \\
220\end{array}$ \\
\hline
\end{tabular}

due to date of seeding was noticeable by the time the third crop was produced.

Redtop is sometimes seeded with a legume such as sweet, white, or alsike clover. While experimental evidence at the Newton and Odin fields shows some benefit to redtop from associative growth with sweet clover, there is also danger that a rank growth of sweet clover may starve or smother the redtop (Table 4). In three trials out of five redtop did not survive on the limed series at Newton. The plots of the regular series, where sweet clover predominated, produced small 
yields of redtop. At Odin, with one exception, the second-year yields of redtop seeded without sweet clover were superior to those of the

Table 4.-Yields of Redtop Seed When Grown With Sweet Clover as a Companion Crop, Newton and Odin Fields

(Pounds per acre)

\begin{tabular}{|c|c|c|c|c|c|c|}
\hline \multicolumn{2}{|c|}{ Newton field, lime series } & \multicolumn{2}{|c|}{ Newton field, regular series } & \multicolumn{3}{|c|}{ Odin field, lime series } \\
\hline Treatment* & $\begin{array}{l}\text { Seed, } \\
\text { average } \\
1929- \\
1930^{\circ}\end{array}$ & Treatmente & $\begin{array}{l}\text { Seed, } \\
\text { average } \\
1932- \\
1933\end{array}$ & Treatment & $\begin{array}{l}\text { Seed. } \\
\text { with } \\
\text { sw. cl. } \\
1930\end{array}$ & $\begin{array}{l}\text { Seed, } \\
\text { without } \\
\text { 8w. cl. } \\
1931\end{array}$ \\
\hline 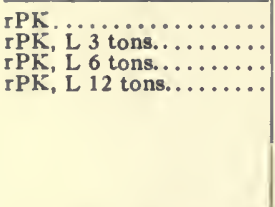 & $\begin{array}{r}53 \\
86 \\
118 \\
96\end{array}$ & 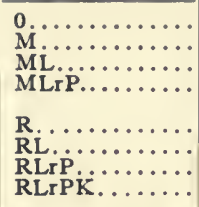 & $\begin{array}{r}124 \\
135 \\
80 \\
70 \\
132 \\
91 \\
86 \\
90\end{array}$ & 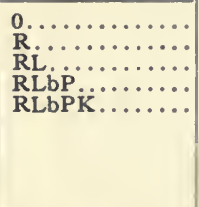 & $\begin{array}{l}26 \\
44 \\
56 \\
52 \\
64\end{array}$ & $\begin{array}{l}60 \\
90 \\
78 \\
99 \\
60\end{array}$ \\
\hline
\end{tabular}

-See footnote b, Table 1. bSweet clover was seeded as a companion crop to redtop each year from 1929 to 1933 . In 1931, 1932, and 1933, however, the sweet clover smothered out the redtop. eOn plots designated ML, MLrP, RL and RLrPK, the sweet clover smothered out the redtop in 1932; on the other plots there were few if any sweet-clover plants. In 1933 there was no sweet clover.

first year with the companion crop. The increased yields the second year may have been due not only to the absence of smothering but also to the benefit of sweet-clover residues.

\section{Harvesting}

Redtop is a crop that will stand for a number of years, depending on the fertility of soil and the use made of the crop. Reporting producers indicated an average duration of six years for their redtop fields, with county averages ranging from three years in Effingham to fifteen in Clinton (Table 5). These fields were harvested for seed five years out of six, or 80 percent of the time; cut for hay 6 percent of the time; and pastured 14 percent of the time. Meadows were pastured 75 days in the fall and 15 days in the spring. Where the meadows are pastured for more of the years and harvested for seed less often, not only do the fields last longer, but yields of seed are increased. Pasturing also helps to prevent the fields from becoming weedy.

In the southern part of the seed area (Fig 2), redtop is commonly cut with a mower for seed as well as for hay, while in the northern part most of the redtop threshed for seed is cut with a binder (Fig. $5)$. The mower is preferred by many for cutting the seed crop where sufficient livestock is not available for a moderate amount of fall pasturing. 


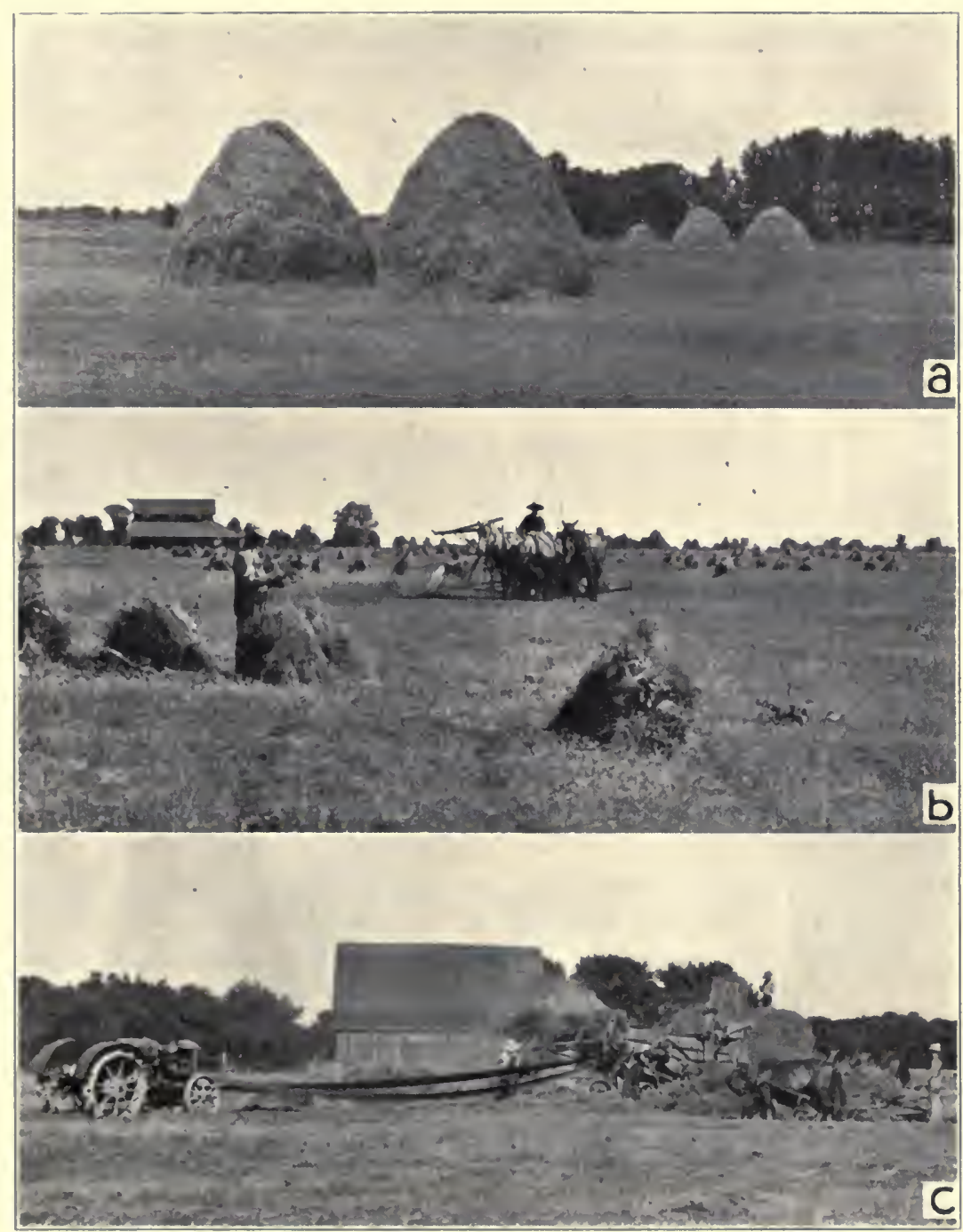

Fig. 5.-Harvesting and Threshing Redtop in Southern Illinois

Redtop stacks such as those in $a$ are a common sight over much of the redtop area in southern Illinois. These stacks may be threshed or fed as roughage without removal of the seed. The seed crop is commonly harvested with a binder $(b)$. Threshing may be done directly from the shock or after stacking, suitable time being allowed for the stacks to go thru a sweat. Note the greater amount of stubble on the ground in $b$ compared with $a$, where cutting was performed with a mower. The threshing scene (c) might be duplicated in almost any part of the redtop area during the early days of August. 
Table 5.-Length of Life of Redtop Fields and Use Made of Them While in Redtop; Data Obtained From 14 Southern Illinois Countiesa

\begin{tabular}{|c|c|c|c|c|c|c|c|c|c|}
\hline \multirow{2}{*}{ County } & \multirow{2}{*}{$\begin{array}{l}\text { Number } \\
\text { of farms } \\
\text { reported }\end{array}$} & \multirow{2}{*}{$\begin{array}{l}\text { Length } \\
\text { of life of } \\
\text { redtop } \\
\text { fields in } \\
\text { years }\end{array}$} & \multirow{2}{*}{$\begin{array}{c}\text { Number } \\
\text { of years } \\
\text { cut for } \\
\text { seed }\end{array}$} & \multirow{2}{*}{$\begin{array}{c}\text { Number } \\
\text { of years } \\
\text { cut for } \\
\text { hay }\end{array}$} & \multirow{2}{*}{$\begin{array}{l}\text { Number } \\
\text { of years } \\
\text { pastured }\end{array}$} & \multicolumn{2}{|c|}{$\begin{array}{l}\text { Fall pasturing } \\
\text { of meadow }\end{array}$} & \multicolumn{2}{|c|}{$\begin{array}{l}\text { Spring pasturing } \\
\text { of meadow }\end{array}$} \\
\hline & & & & & & $\begin{array}{l}\text { Num- } \\
\text { ber of } \\
\text { days }\end{array}$ & Extent & $\begin{array}{l}\text { Num- } \\
\text { ber of } \\
\text { days }\end{array}$ & Extent \\
\hline 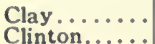 & 18 & 6 & 5 & o & 1 & 65 & Heavy & 10 & Medium \\
\hline $\begin{array}{l}\text { Clinton...... } \\
\text { Cumberland. }\end{array}$ & $\begin{array}{l}2 \\
1\end{array}$ & 15 & 15 & $\mathbf{0}$ & $\mathbf{0}$ & $\cdots$ & ...... & $\cdots$ & $\ldots \ldots$ \\
\hline Edwards..... & 6 & $\ddot{5}$ & $\ddot{2}$ & $\ddot{i}$ & 2 & 45 & Medium & $\ddot{25}$ & Light \\
\hline Effingham... & 1 & 3 & 2 & 1 & $\mathbf{0}$ & $\ldots$ & Light & 0 & 0 \\
\hline Fayette...... & 4 & 7 & 7 & 0 & 0 & 10 & Heavy & 0 & 0 \\
\hline Hamilton.... & 5 & 4 & 3 & 1 & 0 & 30 & Medium & 5 & Medium \\
\hline Jasper....... & 11 & 6 & 4 & 1 & 1 & 70 & Medium & 25 & Medium \\
\hline Jefferson..... & 8 & 5 & 3 & 1 & 1 & 45 & Medium & 10 & Light \\
\hline Marion...... & 12 & 8 & 7 & 1 & 0 & 105 & Medium & 15 & Light \\
\hline Perry. . & 1 & 10 & 9 & 0 & 1 & 60 & Light & 0 & 0 \\
\hline Richland. & 15 & 6 & 5 & 0 & 1 & 90 & Medium & 15 & Light \\
\hline Wayne... & 15 & 6 & 4 & 0 & 2 & 110 & Heavy & 15 & Light \\
\hline White....... & 4 & 5 & 5 & 0 & 0 & 60 & Light & 15 & Light \\
\hline (Not stated).. & 3 & 6 & 6 & 0 & 0 & 30 & Light & 0 & 0 \\
\hline Total for area & 106 & 6.2 & 4.8 & .4 & 1.0 & 75 & Medium & 15 & Light \\
\hline
\end{tabular}

-Each average for total area obtained by dividing by number reported for given item.

The stage at which redtop is cut influences both yield and quality. In deciding when to cut, the producer must often choose between a large yield of redtop seed of lower quality or a moderate yield of higher quality seed. The proper time to harvest in order to obtain plump seed with a distinct silver cast can be determined only by careful observation. At the Newton field the largest seed yields were obtained in 1928 and 1929 from early cuttings (Table 6). The highest quality

Table 6.-Yields of Redtop Seed as Influe nced by Date of Harvest, Newton Field

(Pounds per acre)

\begin{tabular}{|c|c|c|c|c|c|}
\hline \multicolumn{3}{|l|}{1928} & \multicolumn{3}{|l|}{1929} \\
\hline Date of cutting & Bundle & Seed & Date of cutting & Bundle & Seed \\
\hline 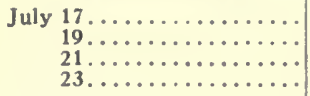 & $\begin{array}{ll}1 & 722 \\
2 & 106 \\
1 & 554 \\
1 & 290\end{array}$ & $\begin{array}{l}44 \\
62 \\
40 \\
31\end{array}$ & 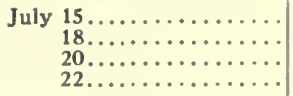 & $\begin{array}{ll}2 & 196 \\
1 & 908 \\
1 & 757 \\
1 & 994\end{array}$ & $\begin{array}{l}84 \\
59 \\
46 \\
50\end{array}$ \\
\hline July $\begin{array}{r}25 \\
27 \\
27 \ldots \ldots \ldots \ldots \ldots \ldots \ldots\end{array}$ & $\begin{array}{ll}1 & 284 \\
2 & 088 \\
2 & 316 \\
2 & 556\end{array}$ & $\begin{array}{l}30 \\
35 \\
47 \\
46\end{array}$ & July $\begin{array}{r}24 \ldots \ldots \ldots \ldots \ldots \ldots \\
26 \ldots \ldots \ldots \ldots \ldots \\
29 \ldots \ldots \ldots \ldots \ldots \\
31 \ldots \ldots \ldots \ldots\end{array}$ & $\begin{array}{ll}1 & 712 \\
1 & 675 \\
1 & 685 \\
2 & 249\end{array}$ & $\begin{array}{l}53 \\
40 \\
28 \\
29\end{array}$ \\
\hline 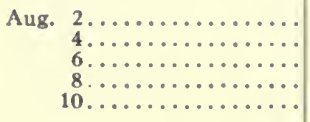 & $\begin{array}{ll}2 & 838 \\
2 & 454 \\
2 & 010 \\
1 & 980 \\
1 & 770\end{array}$ & $\begin{array}{l}51 \\
38 \\
38 \\
31 \\
17\end{array}$ & 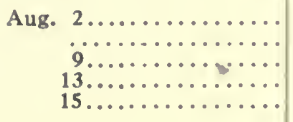 & $\begin{array}{ll}2 & 211 \\
2 & 470 \\
2 & 146 \\
1 & 967\end{array}$ & $\begin{array}{c}19 \\
9 \\
7 \\
7\end{array}$ \\
\hline
\end{tabular}


seed in 1928 was that harvested on July 27, but there was a comparatively low yield. In 1929 the highest yields were also the best in quality. Generally speaking, redtop should be harvested for seed not later than about one week after blooming is completed, because of the danger of loss of seed thru shattering if harvesting is delayed beyond that time. ${ }^{4 *}$

Redtop is cured and stacked very much as timothy is handled. The seed crop is threshed with an ordinary grain thresher with the cylinder and cleaning parts of the machinery adjusted for redtop threshing. In some sections a recleaning attachment is added.

\section{PRODUCTION OF REDTOP IN ILLINOIS}

Redtop is grown extensively over a considerable portion of about 32 counties in southern and southeastern Illinois, altho the bulk of the seed is harvested in a much more restricted area. Production is some-

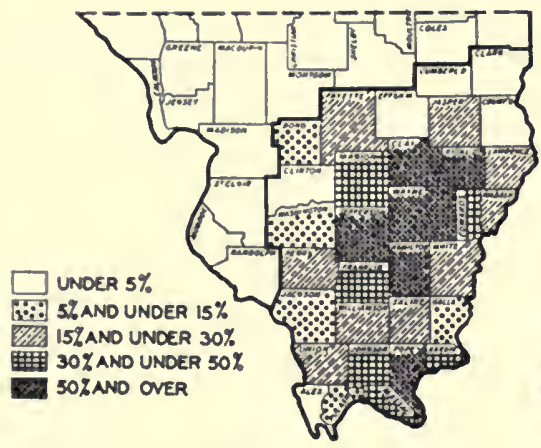

Fig. 6.-FARMS GRowing Redtop (Other Tame Grasses) Cut FOR HAY IN 32 SOUTHERN Illinois Counties, 1929

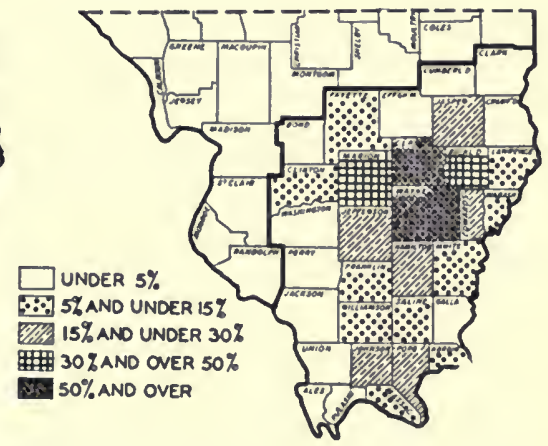

Fig. 7.-Crop Lani Devoten to Rentop (Other Tame Grasses) Cut FOR HAY AND HARVESTED FOR SEED, 1929

what spotted thruout the territory, the crop being cut for hay in 1929 on less than 5 percent of the farms in some counties and on 75 percent in Wayne county (Fig. 6).

The proportion of the total crop land in this district devoted to redtop for hay and seed varied in 1929 from less than 5 percent in 11 counties to 64 percent in Wayne county (Fig 7). In the 21 counties having 5 percent or more of the crop land devoted to redtop grown for hay and seed, the acreage ranked above that of all other crops in 5 counties-Wayne, Marion, Clay, Richland, and Jefferson; second in 7 counties; third in 5 counties; and fourth in 3 counties (Table 7 ). 


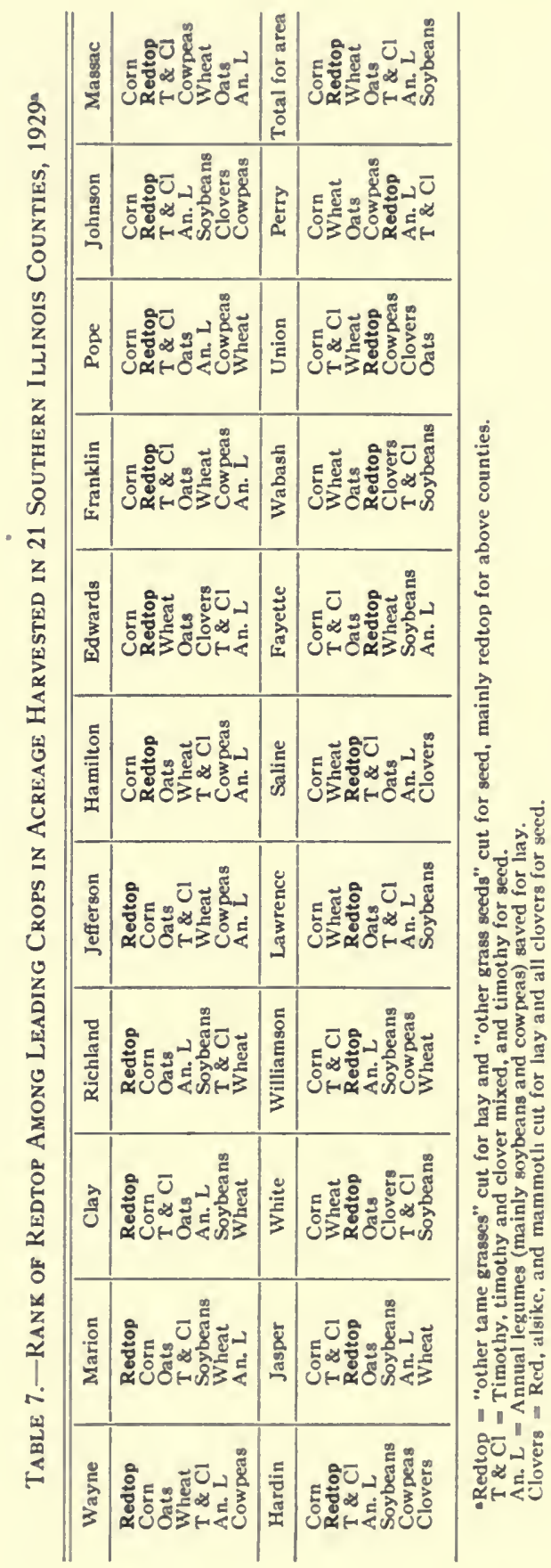


Redtop ranked second to corn in acreage for the area as a whole. Nine crops occupied practically all the harvested land, and each represented the following approximate proportions of the total crop acreage in the 32 counties:

\section{Percent of crop area}

Corn.................. 36

Redtop (hay and seed)....... 28

Wheat................. 10

Oats................. 8

Timothy and clover hay (including timothy for seed)........
Percent of crop area

Annual legumes............. 3

Soybeans............... 3

Clovers (red, mammoth, alsike, and all clovers for seed) ..... 3

Cowpeas................. 2

Farms in the redtop district of Illinois that produce the greatest quantities of redtop have an average area of 224 acres, or about twice that of the average-sized farm of the district. All farms have about the same proportion of the land in harvested crops (Table 8). The

Table 8.-Acreage in Farms, in Cultivated Crops, and in Redtop Reported in 14 SOUTHERN Illino1s Counties, $1932^{\mathrm{a}}$

\begin{tabular}{|c|c|c|c|c|c|c|c|}
\hline \multirow{2}{*}{ County } & \multirow{2}{*}{$\begin{array}{l}\text { Number } \\
\text { of farms } \\
\text { reported }\end{array}$} & \multicolumn{2}{|c|}{ Acres in farms } & \multicolumn{2}{|c|}{$\begin{array}{l}\text { Acres in culti- } \\
\text { vated crops }\end{array}$} & \multicolumn{2}{|c|}{ Acres in redtop } \\
\hline & & Total & $\begin{array}{l}\text { Average } \\
\text { per farm }\end{array}$ & Total & $\begin{array}{l}\text { Average } \\
\text { perfarm }\end{array}$ & Total & $\begin{array}{l}\text { Average } \\
\text { Der farm }\end{array}$ \\
\hline 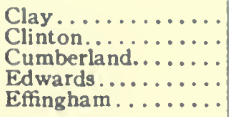 & $\begin{array}{r}18 \\
2 \\
1 \\
6 \\
1\end{array}$ & $\begin{array}{r}4356 \\
557 \\
280 \\
1335 \\
199\end{array}$ & $\begin{array}{l}242 \\
278 \\
280 \\
222 \\
199\end{array}$ & $\begin{array}{r}2436 \\
438 \\
230 \\
569 \\
60\end{array}$ & $\begin{array}{r}134 \\
219 \\
230 \\
114 \\
60\end{array}$ & $\begin{array}{r}1396 \\
96 \\
10 \\
345 \\
40\end{array}$ & $\begin{array}{l}78 \\
48 \\
10 \\
58 \\
40\end{array}$ \\
\hline 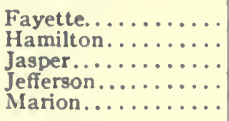 & $\begin{array}{r}4 \\
5 \\
11 \\
8 \\
12\end{array}$ & $\begin{array}{ll}1 & 007 \\
& 510 \\
2 & 662 \\
1 & 220 \\
2 & 733\end{array}$ & $\begin{array}{l}252 \\
128 \\
242 \\
152 \\
249\end{array}$ & $\begin{array}{r}565 \\
329 \\
1005 \\
358 \\
1 \quad 239\end{array}$ & $\begin{array}{r}141 \\
82 \\
91 \\
51 \\
113\end{array}$ & $\begin{array}{r}152 \\
281 \\
1071 \\
345 \\
920\end{array}$ & $\begin{array}{l}38 \\
56 \\
97 \\
43 \\
77\end{array}$ \\
\hline 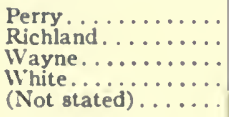 & $\begin{array}{r}1 \\
15 \\
15 \\
4 \\
3\end{array}$ & $\begin{array}{rr} & 80 \\
3 & 949 \\
3 & 117 \\
& 698 \\
& 360\end{array}$ & $\begin{array}{r}80 \\
263 \\
208 \\
174 \\
180\end{array}$ & $\begin{array}{r}20 \\
1 \quad 744 \\
844 \\
385 \\
245\end{array}$ & $\begin{array}{r}20 \\
116 \\
56 \\
96 \\
82\end{array}$ & $\begin{array}{rr} & 50 \\
1 & 606 \\
1 & 642 \\
255 \\
161\end{array}$ & $\begin{array}{r}50 \\
107 \\
109 \\
64 \\
54\end{array}$ \\
\hline Total for area...... & 106 & 23063 & 224 & 10467 & 103 & 8370 & 79 \\
\hline
\end{tabular}

- Each average obtained by dividing by number reported for given item.

farms reporting the uses made of their redtop grew an average of 84 acres per farm, and pastured 40 acres without cutting it. Of the 44 acres cut per farm, an average of 42 acres was harvested for seed, leaving only 2 acres cut for hay (Table 9).

The total acreage in redtop in Illinois in 1929 was approximately as follows: 
Redtop area in Illinois

Redtop area in 32 counties Acres total farm land

Percent of

Redtop hay............ 382000

1.2

Redtop seed............. 226000

.7

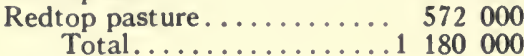

1.9

3.8

Acres total farm land

362000

5.3

225000

3.3

$530000 \quad 7.8$

Total

000

1117000

16.4

Table 9.-Acreage of Redtop Cut, Pastured, and Harvested for Seed REPORTED IN 14 SOUTHERN Illino1s Counties, 1932

\begin{tabular}{|c|c|c|c|c|c|c|c|}
\hline \multirow{2}{*}{ County } & \multirow{2}{*}{$\begin{array}{c}\text { Number } \\
\text { of farms } \\
\text { reported }\end{array}$} & \multicolumn{2}{|c|}{$\begin{array}{l}\text { Acres of redtop cut } \\
\text { (all purposes) }\end{array}$} & \multicolumn{2}{|c|}{$\begin{array}{l}\text { Acres of redtop pas- } \\
\text { tured (not cut) }\end{array}$} & \multicolumn{2}{|c|}{$\begin{array}{l}\text { Acres of redtop } \\
\text { harvested for seeds }\end{array}$} \\
\hline & & Total & $\begin{array}{l}\text { Average } \\
\text { per farm }\end{array}$ & Total & $\begin{array}{l}\text { Average } \\
\text { per farm }\end{array}$ & Total & $\begin{array}{l}\text { Average } \\
\text { per farm }\end{array}$ \\
\hline 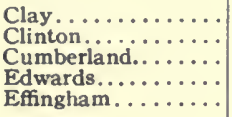 & $\begin{array}{r}18 \\
2 \\
1 \\
6 \\
1\end{array}$ & $\begin{array}{r}772 \\
96 \\
10 \\
145 \\
40\end{array}$ & $\begin{array}{l}43 \\
48 \\
10 \\
24 \\
40\end{array}$ & $\begin{array}{r}624 \\
0 \\
0 \\
200 \\
0\end{array}$ & $\begin{array}{r}37 \\
0 \\
0 \\
50 \\
0\end{array}$ & $\begin{array}{r}752 \\
96 \\
10 \\
110 \\
40\end{array}$ & $\begin{array}{l}42 \\
48 \\
10 \\
28 \\
40\end{array}$ \\
\hline 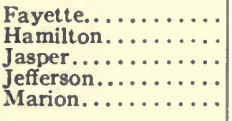 & $\begin{array}{r}4 \\
5 \\
11 \\
8 \\
12\end{array}$ & $\begin{array}{r}92 \\
145 \\
806 \\
218 \\
394\end{array}$ & $\begin{array}{l}23 \\
29 \\
81 \\
27 \\
33\end{array}$ & $\begin{array}{r}60 \\
136 \\
265 \\
127 \\
526\end{array}$ & $\begin{array}{l}20 \\
27 \\
29 \\
18 \\
48\end{array}$ & $\begin{array}{r}92 \\
88 \\
806 \\
143 \\
376\end{array}$ & $\begin{array}{l}23 \\
22 \\
73 \\
24 \\
31\end{array}$ \\
\hline 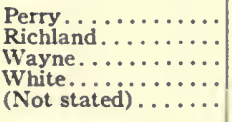 & $\begin{array}{r}1 \\
15 \\
15 \\
4 \\
3\end{array}$ & $\begin{array}{r}30 \\
887 \\
753 \\
70 \\
140\end{array}$ & $\begin{array}{l}30 \\
59 \\
50 \\
18 \\
47\end{array}$ & $\begin{array}{r}20 \\
719 \\
889 \\
185 \\
21\end{array}$ & $\begin{array}{r}20 \\
51 \\
64 \\
46 \\
7\end{array}$ & $\begin{array}{r}30 \\
867 \\
681 \\
50 \\
120\end{array}$ & $\begin{array}{l}30 \\
58 \\
49 \\
12 \\
40\end{array}$ \\
\hline Total for area...... & 106 & 4598 & 44 & 3772 & 40 & 4261 & 42 \\
\hline
\end{tabular}

-Each average obtained by dividing by number reported for given item.

\section{Seed}

Acreage.-Redtop harvested for seed in Illinois has varied in acreage from year to year, and has shown considerable tendency to be up for two years and then down for two years. The acreage harvested for seed continued upward thru 1931 and then moved downward rather sharply. Acreage harvested for seed in the state during 19221932 ranged from 150,000 acres in 1922 to 272,700 in 1931 with an average of 204,800 for the period 1922-1933 (Table 10).

A study of acreage of redtop harvested for seed, by counties in Illinois, indicates that the bulk of the seed is produced in a more restricted area than is the hay, but is centered in the same counties (Fig. 8).

Yicld.-Yield of redtop seed averaged 54 pounds an acre for the period 1922-1932 but varied from 30 pounds in 1925 to 75 pounds in 1927 (Table 10). Variation in yield from year to year has been a greater factor in variation in production than has change in total 
Table 10.-Acreage, Yield, and Production of Redtop Harvested For SeEd, United States ${ }^{a}$

(In carlots of 30,000 pounds)

\begin{tabular}{|c|c|c|c|}
\hline Year & $\begin{array}{l}\text { Acres } \\
\text { threshedb }\end{array}$ & $\begin{array}{l}\text { Yield } \\
\text { per acre }\end{array}$ & $\begin{array}{l}\text { Production } \\
\text { (carlots) }\end{array}$ \\
\hline 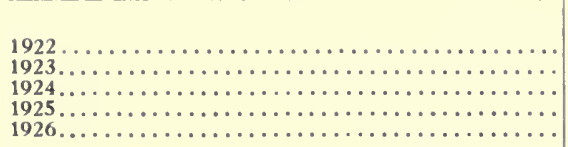 & $\begin{array}{ll}150 & 000 \\
160 & 700 \\
162 & 900 \\
200 & 000 \\
183 & 300\end{array}$ & $\begin{array}{c}l b s . \\
65 \\
70 \\
65 \\
30 \\
45\end{array}$ & $\begin{array}{l}325 \\
380 \\
350 \\
200 \\
275\end{array}$ \\
\hline 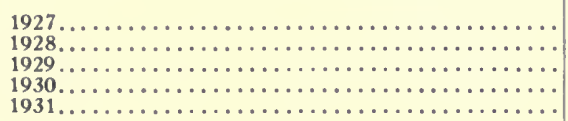 & $\begin{array}{ll}240 & 000 \\
237 & 500 \\
214 & 900 \\
208 & 300 \\
272 & 700\end{array}$ & $\begin{array}{l}75 \\
60 \\
37 \\
36 \\
66\end{array}$ & $\begin{array}{l}600 \\
475 \\
265 \\
250 \\
600\end{array}$ \\
\hline $\begin{array}{l}1932 \ldots \ldots \ldots \ldots \ldots \ldots \ldots \ldots \ldots \ldots \ldots \ldots \ldots \ldots \ldots \ldots \ldots \ldots \ldots \ldots \ldots \\
1933 \ldots \ldots \ldots \ldots \ldots \ldots \ldots \ldots \ldots \ldots\end{array}$ & $\begin{array}{l}256500 \\
171400\end{array}$ & $\begin{array}{l}62 \\
35\end{array}$ & $\begin{array}{l}530 \\
200\end{array}$ \\
\hline Average...$\ldots \ldots \ldots \ldots \ldots \ldots \ldots$ & 204800 & 54 & 370 \\
\hline
\end{tabular}

- Proportion outside of Illinois averaged less than 5 percent of total. bCalculated on basis of total production and yields per acre.

acreage. Differences in yield from county to county were pronounced during both 1931 and 1932. Counties in the northern half of the seedproducing area tended to show higher yields than those in the southern half (Table 11).

Production.-Domestic production of redtop seed averaged 370 carloads or $11,120,000$ pounds of cleaned seed for the period 19221933 (Table 10). There was a wide variation from year to year,

Table 11.-Acreage of Redtop Harvested for Seed, Yield of Seed, and Yield of Straw per Acre Reported in 14 Southern Illinois Counties

\begin{tabular}{|c|c|c|c|c|c|c|c|}
\hline \multirow{2}{*}{ County } & \multirow{2}{*}{$\begin{array}{l}\text { Number } \\
\text { of farms } \\
\text { reported }\end{array}$} & \multicolumn{2}{|c|}{ Acres in farms } & \multicolumn{2}{|c|}{$\begin{array}{l}\text { Average yield of } \\
\text { clean seed }\end{array}$} & \multicolumn{2}{|c|}{$\begin{array}{c}\text { Average yield } \\
\text { of straw }\end{array}$} \\
\hline & & 1931 & 1932 & 1931 & 1932 & 1931 & 1932 \\
\hline 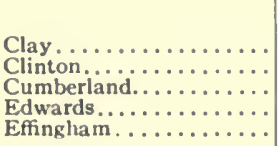 & $\begin{array}{r}18 \\
2 \\
1 \\
6 \\
1\end{array}$ & $\begin{array}{r}741 \\
96 \\
10 \\
168 \\
40\end{array}$ & $\begin{array}{r}752 \\
96 \\
10 \\
110 \\
40\end{array}$ & $\begin{array}{r}\text { lbs. } \\
68 \\
78 \\
120 \\
73 \\
88\end{array}$ & $\begin{array}{r}\text { lbs. } \\
64 \\
120 \\
58 \\
88\end{array}$ & $\begin{array}{r}\text { Lons } \\
.63 \\
.70 \\
.70 \\
.79 \\
.25\end{array}$ & $\begin{array}{c}\text { tons } \\
.66 \\
\ldots \\
.0 \\
.69 \\
.25\end{array}$ \\
\hline 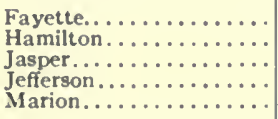 & $\begin{array}{r}4 \\
5 \\
11 \\
8 \\
12\end{array}$ & $\begin{array}{r}82 \\
138 \\
878 \\
232 \\
616\end{array}$ & $\begin{array}{r}92 \\
88 \\
806 \\
143 \\
376\end{array}$ & $\begin{array}{l}67 \\
45 \\
67 \\
40 \\
75\end{array}$ & $\begin{array}{l}68 \\
14 \\
73 \\
36 \\
88\end{array}$ & $\begin{array}{l}.44 \\
.80 \\
.55 \\
.67 \\
.69\end{array}$ & $\begin{array}{l}.44 \\
.50 \\
.58 \\
.69 \\
.62\end{array}$ \\
\hline 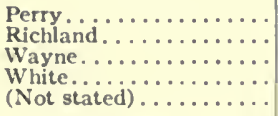 & $\begin{array}{r}1 \\
15 \\
15 \\
4 \\
3\end{array}$ & $\begin{array}{r}45 \\
897 \\
867 \\
80 \\
150\end{array}$ & $\begin{array}{r}30 \\
867 \\
681 \\
50 \\
120\end{array}$ & $\begin{array}{l}19 \\
63 \\
63 \\
62 \\
53\end{array}$ & $\begin{array}{l}64 \\
51 \\
46 \\
98\end{array}$ & $\begin{array}{r}.31 \\
.70 \\
.76 \\
.75 \\
.36\end{array}$ & $\begin{array}{l}.32 \\
.62 \\
.57 \\
.62 \\
.50\end{array}$ \\
\hline Total for area .......... & 106 & 5033 & 4261 & 65 & 66 & .66 & .60 \\
\hline
\end{tabular}

- Each average obtained by dividing by number reported for given item. 
production being as low as 200 carloads in 1925 and 1933 and as high as 600 carloads in 1927 and 1931. Production per farm for reporting farms in the Illinois redtop district in 1931 and 1932 averaged about

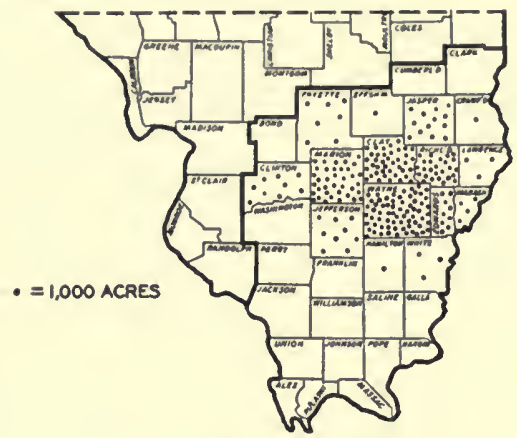

Fig. 8.-Seed Acreage of Redtop in 32 Southern Illinois Counties, 1929

Redtop seed acreage (other tame grasses) gives the same picture as redtop seed production except for slightly greater yields in the northern part of the territory. Nearly 75 percent of the total redtop acreage harvested for seed in Illinois in 1929 was in Wayne, Clay, Marion, and Richland counties. In Jasper, Clinton, Jefferson, Edwards, and Fayette counties a considerable acreage was harvested for seed, the total in the five counties amounting to 20 percent of the total Illinois redtop acreage harvested for seed in that year.

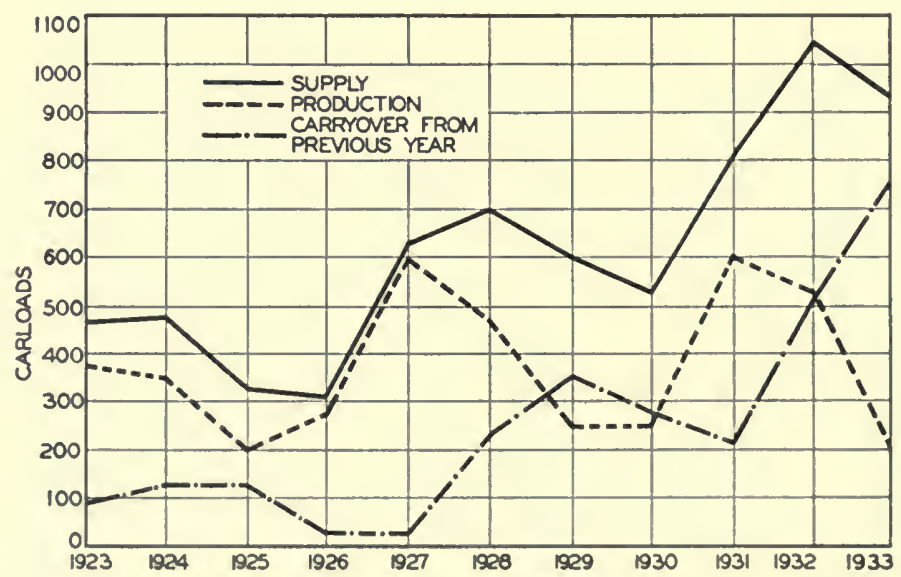

Fig. 9.-Supply, Production, and Carryover of Redtop Seed in the United States for the Crop Years 1923-1933

Except for the decrease in production in 1929 and 1930, and some decrease in carryover in 1930 and 1931, conditions have been conducive to a piling up of redtop supplies since 1926. 
3,000 pounds of cleaned seed, ranging from 1,200 pounds in each of four counties to more than 5,000 pounds in Jasper (Table 12). The average production per farm for the four leading redtop-producing counties of Wayne, Marion, Clay, and Richland (Table 7, page 242) was about 3,400 pounds.

Table 12.-Acreage and Production of Redtop Seed Reported in 14 SOUTHERN IllinoIS Counties ${ }^{\mathrm{A}}$

\begin{tabular}{|c|c|c|c|c|c|c|c|}
\hline \multirow{3}{*}{ County } & \multirow{3}{*}{$\begin{array}{l}\text { Number } \\
\text { of farms } \\
\text { reported }\end{array}$} & \multirow{2}{*}{\multicolumn{2}{|c|}{ Acres in farms }} & \multicolumn{4}{|c|}{ Production of clean seed } \\
\hline & & & & \multicolumn{2}{|c|}{1931} & \multicolumn{2}{|c|}{1932} \\
\hline & & 1931 & 1932 & Total & $\begin{array}{l}\text { Average } \\
\text { Derfarm }\end{array}$ & Total & $\begin{array}{l}\text { Average } \\
\text { per farm }\end{array}$ \\
\hline 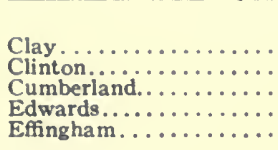 & $\begin{array}{r}18 \\
2 \\
1 \\
6 \\
1\end{array}$ & $\begin{array}{r}741 \\
96 \\
10 \\
168 \\
40\end{array}$ & $\begin{array}{r}752 \\
96 \\
10 \\
110 \\
40\end{array}$ & $\begin{array}{rl} & \text { lbs. } \\
37 & 428 \\
7 & 531 \\
1 & 200 \\
10 & 126 \\
3 & 500\end{array}$ & $\begin{array}{ll} & l b s . \\
2 & 495 \\
3 & 766 \\
1 & 200 \\
2 & 025 \\
3 & 500\end{array}$ & $\begin{array}{rl} & l b s . \\
48 & 055 \\
\mathrm{i} & 200 \\
6 & 396 \\
3 & 500\end{array}$ & $\begin{array}{ll} & \text { lbs. } \\
2 & 670 \\
1 & 200 \\
1 & 200 \\
1 & 500\end{array}$ \\
\hline 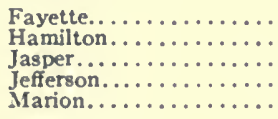 & $\begin{array}{r}4 \\
5 \\
11 \\
8 \\
12\end{array}$ & $\begin{array}{r}82 \\
138 \\
878 \\
232 \\
616\end{array}$ & $\begin{array}{r}92 \\
88 \\
806 \\
143 \\
376\end{array}$ & $\begin{array}{rl}5 & 480 \\
6 & 162 \\
52 & 397 \\
7 & 262 \\
43 & 678\end{array}$ & $\begin{array}{ll}1 & 370 \\
1 & 232 \\
5 & 240 \\
1 & 037 \\
3 & 971\end{array}$ & $\begin{array}{rl}6 & 290 \\
& 840 \\
53 & 366 \\
4 & 822 \\
29 & 570\end{array}$ & $\begin{array}{ll}1 & 572 \\
& 210 \\
5 & 337 \\
1 & 206 \\
2 & 957\end{array}$ \\
\hline 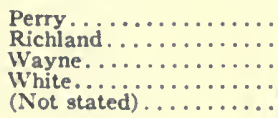 & $\begin{array}{r}1 \\
15 \\
15 \\
4 \\
3\end{array}$ & $\begin{array}{r}45 \\
897 \\
867 \\
80 \\
150\end{array}$ & $\begin{array}{r}30 \\
867 \\
681 \\
50 \\
120\end{array}$ & $\begin{array}{rl} & 855 \\
49 & 948 \\
52 & 957 \\
4921 \\
7948\end{array}$ & $\begin{array}{ll} & 855 \\
3 & 842 \\
4 & 413 \\
1 & 230 \\
2 & 649\end{array}$ & $\begin{array}{r}519926 \\
33495 \\
920 \\
9840\end{array}$ & $\begin{array}{l}3909 \\
33045 \\
307 \\
4 \quad 920\end{array}$ \\
\hline Total for area.......... & 106 & 5033 & 4261 & 291393 & 3100 & 250220 & 2910 \\
\hline
\end{tabular}

-Each average obtained by dividing by number reported for given item.

Carryover. - In addition to the yearly production of redtop seed the carryover has been significant in determining the total supply available for commercial consumption from year to year. Carryover was small prior to the extraordinarily large crop of 1927 but has been a vital factor in contributing to the large supply available since the time that the 1928 crop entered market channels (Fig. 9).

When production and carryover are combined to obtain total supply of seed, the resulting figures show an increase from the low total of 310 carloads in 1926 to 1,040 carloads in 1933.

\section{Straw}

Yield.-The acre-yield of redtop straw (a byproduct of redtop. threshed for seed) for 1931 and 1932 on the reported farms was about .66 and .60 ton respectively (Table 11). This was about five-sixths of the yield of redtop hay obtained during these two years. The difference in yield is attributed to loss of weight of seed in threshing and to extra stubble remaining in the meadow when cut with a binder. 
Production.-Redtop straw has not been given much market consideration in recent years, the commercial outlet for it having largely disappeared. Nevertheless redtop straw adds materially to the available supply of winter roughage on farms in the redtop district. Calculated on the basis of (1) estimated number of acres harvested for seed in Illinois in 1931 and (2) acre-yield of straw as reported to the Agricultural Experiment Station, a total of more than 160,000 tons of redtop straw was available for feed from the 1931 crop.

\section{Hay}

Acreage.-The downward trend in acreage of redtop hay from 390,000 acres in 1924 to 224,000 in 1932 and the yearly variations (Table 13) are understandable in the light of changing prices of red-

Table 13.-Acreage, Yield, and Production of "Other Miscellaneous HAY" IN IllinOIS

\begin{tabular}{|c|c|c|c|}
\hline Year & Acres in hay & Yield per acre & Production \\
\hline 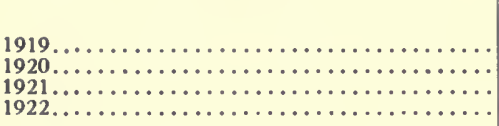 & $\begin{array}{l}355000 \\
314000 \\
342000 \\
335000\end{array}$ & $\begin{array}{l}\text { tons } \\
.80 \\
.80 \\
.90 \\
.80\end{array}$ & $\begin{array}{l}\text { tons } \\
284000 \\
251000 \\
308000 \\
268000\end{array}$ \\
\hline 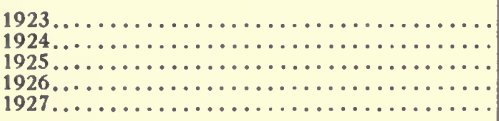 & $\begin{array}{l}344000 \\
390000 \\
234000 \\
269000 \\
296000\end{array}$ & $\begin{array}{l}.95 \\
.80 \\
.60 \\
.70 \\
.90\end{array}$ & $\begin{array}{ll}327 & 000 \\
312 & 000 \\
140 & 000 \\
188 & 000 \\
266 & 000\end{array}$ \\
\hline 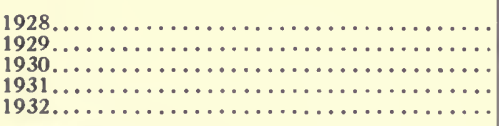 & $\begin{array}{l}326000 \\
329000 \\
280 \\
280000 \\
224000\end{array}$ & $\begin{array}{l}.80 \\
.80 \\
.60 \\
.75 \\
.75\end{array}$ & $\begin{array}{l}261000 \\
263000 \\
168000 \\
210000 \\
168000\end{array}$ \\
\hline Average $1923-1932 \ldots \ldots \ldots \ldots \ldots \ldots \ldots$ & 297000 & .77 & 230000 \\
\hline
\end{tabular}

top seed discussed on pages 265 to 272 . Statistics for the 32 counties in the redtop district show that 18 counties had an increase in redtop acreage cut for hay between 1919 and 1924, and then a decrease be-

"Redtop hay acreage as such is not reported by either the Illinois Crop Reporting Service or the Federal Census but is reported under the classifications of "other miscellaneous hay" and "other tame grasses" respectively. In both classifications such other hays as millet, Sudan, etc., are included, but they constitute a small proportion of the total for Illinois and particularly so for the important redtop counties. The classifications of hays used in the 1930 Census were: all hays, timothy and timothy and clover mixed; clovers, red, alsike, and mammoth; clovers, sweet, crimson, and Japan; clovers alone, all kinds; alfalfa, other tame grasses; wild grasses cut on farms; small grains cut for hay; and annual legumes cut for hay." 
tween 1924 and 1929 (Fig. 10). Only 7 counties-Bond, Fayette, Hamilton, Jefferson, Lawrence, Union, and Wayne-showed an increase in acreage thruout the period 1919-1929.

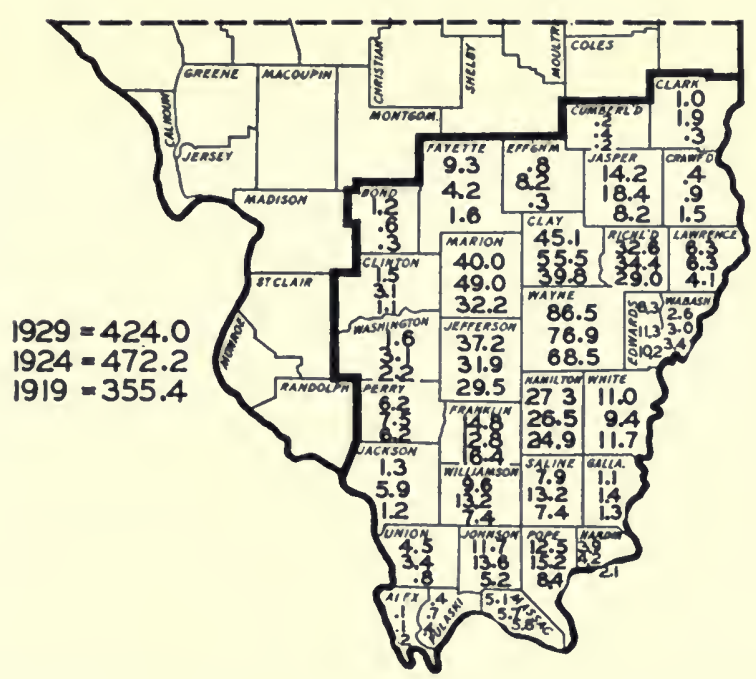

Fig. 10.-Acreage of Redtop Cut for Hay in 32 Southern Illinois Counties, 1919, 1924, AND 1929 (Thousands of acres)

Marked increase in redtop hay acreage (other tame grasses) for 1929 over 1924 was concentrated in Wayne, Jefferson, Franklin, Hamilton, and White counties. The 32 counties in the redtop district contained more than 95 percent of the redtop hay acreage in Illinois in 1929.

Redtop hay acreage represented over two-fifths of the total acreage of all crops cut for hay in 1929 in these 32 counties and over threefifths in the 16 of the 32 counties having the most redtop hay. The relative proportion which each of the different hay acreages represented of the total was as follows:

\section{$32 \quad 16$ counties counties perct. perct.}

Other tame grasses.... $44.1 \quad 62.1$

Timothy, mixed with clover and unmixed $31.2 \quad 21.1$ Annual legumes...... 12.2 10.2 Clovers-red, alsike, and mammoth.... $8.1 \quad 4.1$
$32 \quad 16$ counties counties perct. perct.

Alfalfa............ $2.4 \quad 1.0$

Small grain......... $\quad .9 \quad .6$

Wild grasses......... $\quad .6 \quad .5$

Clovers-sweet, crimson, and Japan.... $\quad .6 \quad .3$

Yield.-Yields of redtop hay in Illinois for the ten-year period 1923-1932 ranged from .60 ton an acre in 1925 and 1930 to .95 ton in 
1923 and averaged .77 ton (Table 13). This average yield was about two-thirds of the average for all tame hay in Illinois and five-sixths of the average yield of tame hay in the 32 redtop counties.

Production.-Production of redtop hay in Illinois averaged 230,000 tons for the ten-year period 1923-1932, ranging from 327,000 tons in

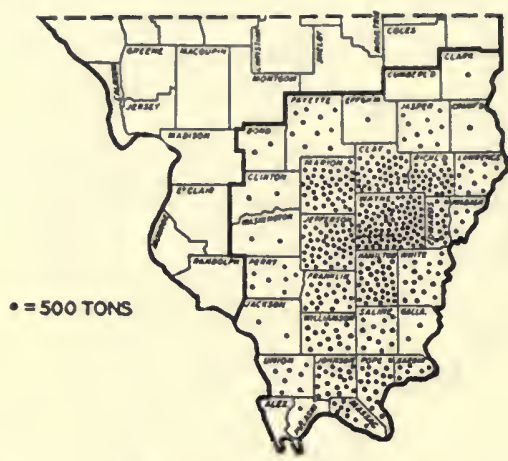

Fig. 11.-Production of Hay From Redtop in 32

Southern Illinois Counties, 1929

Redtop hay production (other tame grasses) has been rather dense over most of these 32 counties except for the counties in the north and west tiers. Wayne, Jefferson, Marion, Clay, Hamilton, and Richland counties produced more than 55 percent of the state's total production of redtop hay in 1929.

1923 to 140,000 tons in 1925 (Table 13 ). The 32 redtop counties produced more than 95 percent of the total amount of redtop hay in Illinois in 1929 (Fig. 11).

\section{Pasture}

Acreage.-Adequate information concerning acreage devoted to redtop pasture as such is not available. From a comparison of hay and pasture acreage for the redtop district and for the entire state, a fair estimate of the amount of pasture that was predominantly redtop in 1929 would seem to be about 530,000 acres for the 32 counties in the redtop district and 572,000 acres for the state (see page 244 ). The proportion of farm land devoted to all pasture for the 32 counties as a whole was 19.1 percent and to redtop pasture for the reporting farms, 18.2 percent.

Yield.-No record was obtained on pasture yields but it is customary to figure the pasturage from 3 acres as sufficient to maintain an animal unit (mature cow or horse) thru an average pasture season of approximately 180 days. This gives about 60 pasture days an acre 
from redtop used exclusively for pasture. In addition to the acreage of redtop used exclusively for pasture, most redtop fields harvested for hay or seed are pastured lightly for about 15 days in the spring and about 75 days in the fall after the crop is harvested. This amounts to about 25 pasture days an acre from harvested areas. (Table 5, page 240)

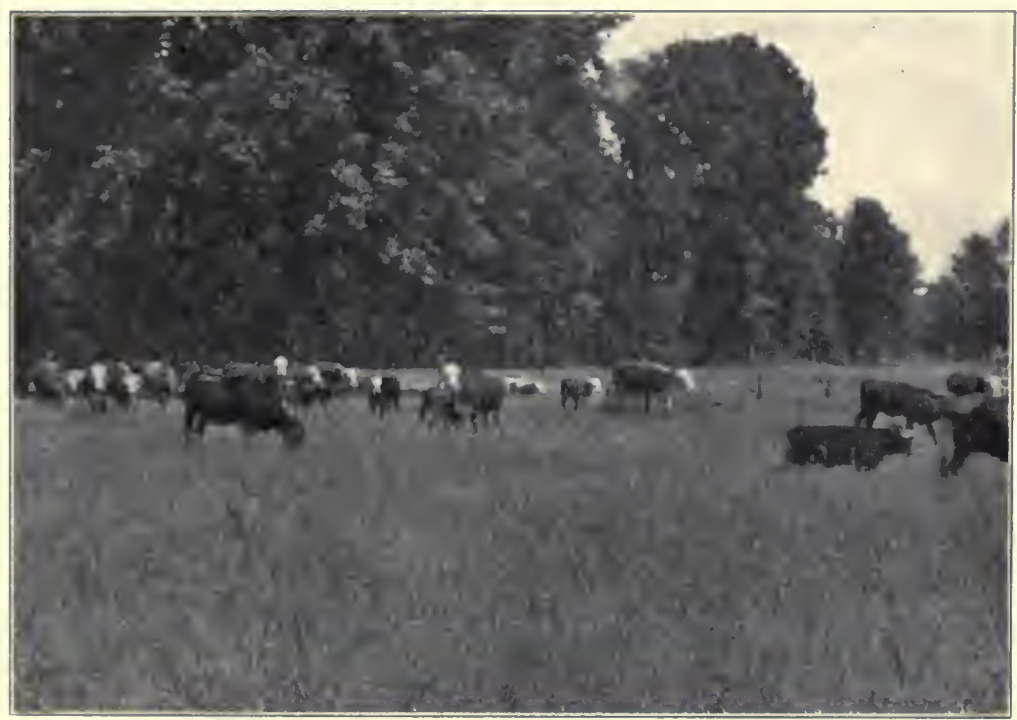

Fig. 12.-Cattle Are Grazed Extensively od Redtop Pastures in Southern Illinois

Redtop is an important part of most pastures in southern Illinois, and cattle are the most important livestock grazed on these pastures.

Production.-On the basis of 25 pasture-days from each acre of redtop meadow and 60 pasture-days from each acre of redtop pasture, as estimated for 1929, a total yearly amount sufficient to carry 200,000 animals for 200 days was available in the 32 counties of the Illinois redtop district, and in the state as a whole an amount sufficient to carry 225,000 animals for 200 days.

\section{DISPOSITION MADE OF THE REDTOP CROP IN ILLINOIS}

Hay.-Altho there was an average yearly production of 230,000 tons of redtop hay in Illinois during the ten-year period 1923-1932, practically none entered commercial channels during the last five years of this period. The commercial outlet for redtop hay has almost dis- 
appeared along with the marked contraction in the timothy hay market. That growers have made some adjustment to the new situation is indicated by the 25-percent reduction in the amount of hay produced for the period 1928-1932 compared with the period 1919-1923.

Commercial movement in recent years has been restricted almost entirely to local purchases. Supply has been above local requirements frequently, however, and it is not uncommon to see farm stacks of hay two and three years old. This surplus was increased somewhat in the

\section{Table 14.-Production, Carryover, and Disappearance of Redtop SEed, United States ${ }^{a}$}

(In carlots of 30,000 pounds)

\begin{tabular}{|c|c|c|c|c|c|}
\hline \multirow{2}{*}{ Crop } & \multicolumn{3}{|c|}{ Supply } & \multirow{2}{*}{$\begin{array}{l}\text { Disappear- } \\
\text { ance }\end{array}$} & \multirow{2}{*}{$\begin{array}{l}\text { Stocks at } \\
\text { end of year }\end{array}$} \\
\hline & Total & Crop & Carryover & & \\
\hline $1922 \ldots \ldots \ldots \ldots \ldots \ldots \ldots \ldots \ldots \ldots$ & $\cdots$ & 325 & large & $\cdots$ & 90 \\
\hline 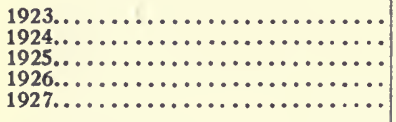 & $\begin{array}{l}470 \\
475 \\
325 \\
310 \\
625\end{array}$ & $\begin{array}{l}380 \\
350 \\
200 \\
275 \\
600\end{array}$ & $\begin{array}{r}90 \\
125 \\
125 \\
35 \\
25\end{array}$ & $\begin{array}{l}340 \\
350 \\
290 \\
285 \\
375\end{array}$ & $\begin{array}{r}130 \\
125 \\
35 \\
25 \\
250\end{array}$ \\
\hline 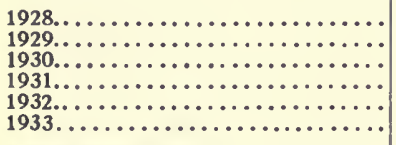 & $\begin{array}{r}700 \\
615 \\
525 \\
810 \\
1040 \\
940\end{array}$ & $\begin{array}{l}475 \\
265 \\
250 \\
600 \\
530 \\
200\end{array}$ & $\begin{array}{l}225 \\
350 \\
275 \\
210 \\
510 \\
740\end{array}$ & $\begin{array}{l}350 \\
340 \\
315 \\
300 \\
300 \\
\cdots\end{array}$ & $\begin{array}{l}350 \\
275 \\
210 \\
510 \\
740 \\
\cdots\end{array}$ \\
\hline A verage $1923-1933 \ldots \ldots \ldots \ldots \ldots$ & 590 & 390 & 195 & 325 & 365 \\
\hline
\end{tabular}

- Proportion outside of Illinois averaged less than 5 percent.

three years 1931-1933 as a consequence of the low price of seed. Ordinarily the surplus stacks would have been threshed for seed within a year.

Straw.-Many farmers in the redtop district consider redtop straw to be almost as desirable as redtop hay for roughage; others even prefer a feed from which the seed has been removed. Where redtop seed is retained in the feed, livestock tend to slobber and because of the bitter taste of the seed do not relish it.

During the period when there was a good commercial market for hay, redtop straw possessed a market demand as well, but very little straw now moves into commercial channels for feeding purposes. A small amount of redtop straw has been purchased by paper-box concerns but the price has been so low that there has been little margin available for absorbing transportation costs.

In recent years producers have faced the problem of dividing the acreage on individual farms in such a way between redtop used pri- 
marily for pasture and that harvested for seed that sufficient livestock might be carried to utilize all of the roughage produced.

Seed.-For some years past redtop seed has been the only product from the redtop crop having a commercial outlet. Yearly supplies showed a strong upward trend during the ten-year period 1923-1932 because of increase both in production and carryover, while disappearance of seed showed only a very slight trend upward (Table 14 and Fig. 13).

Except as retained to meet the relatively small planting requirements of near-by producers, the redtop seed crop which is used entire-

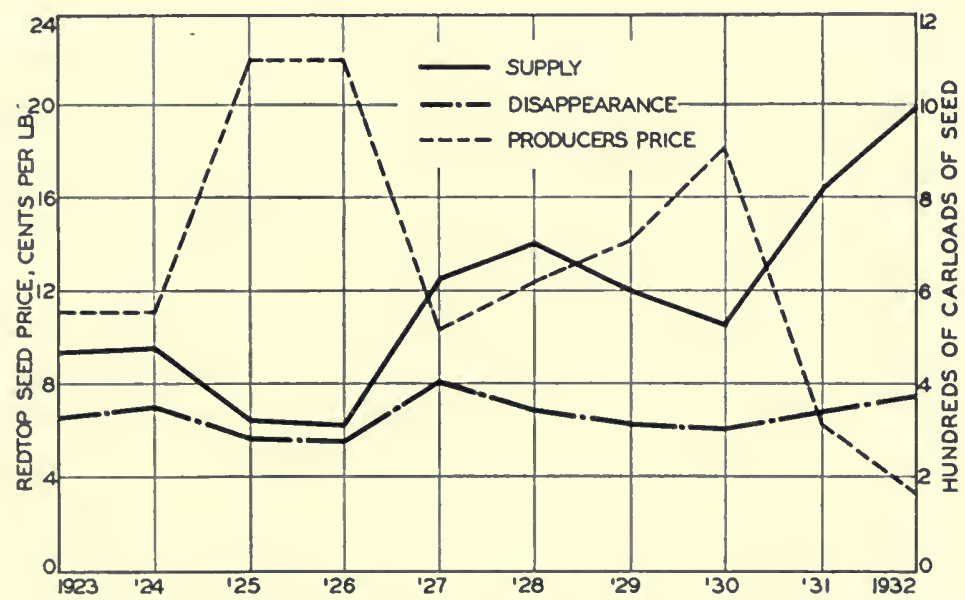

Fig. 13.-Supply and Disappearance of Redtop Seed in the United States for the Crop Years 1923-1932, and Prices Paid to Producers

While redtop supplies have increased greatly since 1926, disappearance has remained stable. Price has reacted sharply to changes in supplies but only slightly to variations in disappearance.

ly for seed plantings must go into commercial channels. The crop is harvested mainly during the second half of July and moves rapidly out of the growers' hands. During 1922-1932 an average of 20 percent moved out of growers' hands by August 15, 65 percent by September 15, 85 percent by October 15, and 90 percent by November 15 (Table 15).

Information concerning the movement of redtop seed out of local dealers' hands indicates in part where the seed has been utilized. In approximate terms the movement for the $1931 \mathrm{crop}$, expressed in percentage of supply moved to reported destinations, was as follows: 


\section{Percent of} supply

To Chicago............. 60

To Louisville............. 10

To Buffalo and other New York points..................

10

Percent of supply

To Cincinnati............ 5

To Kentucky and Tennessee... 5

To all other points... ..... 5

A further indication of the widespread distribution of redtop sales is afforded in the reports of retail sales published annually by the U. S. Bureau of Agricultural Economics, and covering at least a part of the

Table 15.-Proportion of Redtop Seed Crop Moved Out of Hands of Growers by Four SPECIFIEd DATES

(In percent of total crop)

\begin{tabular}{|c|c|c|c|c|c|}
\hline Year & $\begin{array}{l}\text { Date of starting } \\
\text { general harvesting }\end{array}$ & Aug. 15 & Sept. 15 & Oct. 15 & Nov. 15 \\
\hline 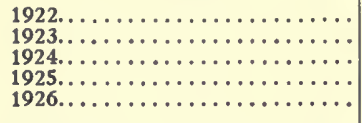 & $\begin{array}{l}\text { July } 8 \\
\cdots \cdots \\
\text { July } 16 \\
\text { July } 18\end{array}$ & $\begin{array}{r}25 \\
5 \\
20 \\
40 \\
10\end{array}$ & $\begin{array}{l}85 \\
65 \\
60 \\
85 \\
65\end{array}$ & $\begin{array}{c}90 \\
75 \\
70 \\
95 \\
85-90\end{array}$ & $\begin{array}{l}\cdots \\
\cdots \\
\cdots \\
\cdots\end{array}$ \\
\hline 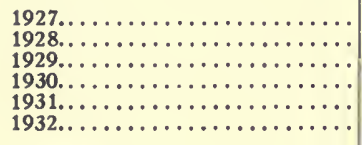 & $\begin{array}{ll}\text { July } & 17 \\
\text { July } & 19 \\
\text { July } & 18 \\
\text { July } & 14 \\
\text { July } & 13 \\
\text { July } & 12\end{array}$ & $\begin{array}{r}5 \\
5 \\
10 \\
65 \\
5 \\
30\end{array}$ & $\begin{array}{l}50 \\
60 \\
65 \\
90 \\
35 \\
70\end{array}$ & $\begin{array}{c}75 \\
85-90 \\
85-90 \\
95 \\
50-55 \\
80\end{array}$ & $\begin{array}{l}90 \\
90-95 \\
\cdots \\
\ddot{85}-90 \\
\cdots\end{array}$ \\
\hline 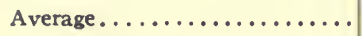 & July 15 & 20 & 65 & 85 & 90 \\
\hline
\end{tabular}

Table 16.-Relative Volume of Retail Sales of Redtop Seed by States $(1923$ sales $=100)$

\begin{tabular}{|c|c|c|c|c|c|c|c|c|c|c|c|}
\hline State & 1924 & 1925 & 1926 & 1927 & 1928 & 1929 & 1930 & 1931 & 1932 & 1933 & $\begin{array}{l}\text { Average } \\
1923 \\
1933\end{array}$ \\
\hline 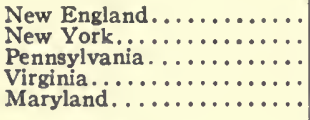 & $\begin{array}{r}100 \\
135 \\
112 \\
100 \\
85\end{array}$ & $\begin{array}{l}110 \\
122 \\
114 \\
108 \\
\cdots\end{array}$ & $\begin{array}{r}99 \\
116 \\
128 \\
109 \\
\cdots\end{array}$ & $\begin{array}{r}96 \\
115 \\
118 \\
106 \\
\cdots\end{array}$ & $\begin{array}{r}97 \\
115 \\
142 \\
120 \\
\cdots\end{array}$ & $\begin{array}{r}91 \\
108 \\
146 \\
114 \\
\cdots\end{array}$ & $\begin{array}{r}92 \\
114 \\
133 \\
113 \\
\cdots\end{array}$ & $\begin{array}{r}88 \\
115 \\
140 \\
113 \\
\cdots\end{array}$ & $\begin{array}{r}91 \\
115 \\
140 \\
101 \\
\cdots\end{array}$ & $\begin{array}{r}100 \\
115 \\
28 \\
86 \\
\cdots\end{array}$ & $\begin{array}{r}96 \\
115 \\
118 \\
104 \\
\cdots\end{array}$ \\
\hline 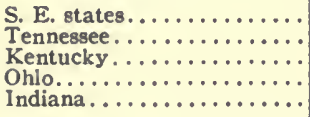 & $\begin{array}{r}107 \\
96 \\
109 \\
100 \\
97\end{array}$ & $\begin{array}{r}125 \\
104 \\
122 \\
100 \\
98\end{array}$ & $\begin{array}{r}108 \\
94 \\
105 \\
95 \\
99\end{array}$ & $\begin{array}{r}108 \\
87 \\
117 \\
90 \\
99\end{array}$ & $\begin{array}{r}118 \\
91 \\
121 \\
93 \\
98\end{array}$ & $\begin{array}{r}106 \\
92 \\
129 \\
89 \\
96\end{array}$ & $\begin{array}{r}119 \\
86 \\
135 \\
86 \\
97\end{array}$ & $\begin{array}{r}125 \\
80 \\
123 \\
81 \\
91\end{array}$ & $\begin{array}{r}101 \\
61 \\
119 \\
75 \\
82\end{array}$ & $\begin{array}{r}61 \\
73 \\
113 \\
68 \\
86\end{array}$ & $\begin{array}{r}107 \\
89 \\
118 \\
89 \\
95\end{array}$ \\
\hline 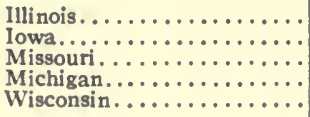 & $\begin{array}{r}103 \\
100 \\
101 \\
105 \\
98\end{array}$ & $\begin{array}{r}108 \\
104 \\
102 \\
99 \\
98\end{array}$ & $\begin{array}{r}104 \\
100 \\
100 \\
91 \\
149\end{array}$ & $\begin{array}{r}107 \\
114 \\
95 \\
102 \\
153\end{array}$ & $\begin{array}{r}106 \\
133 \\
96 \\
109 \\
168\end{array}$ & $\begin{array}{l}120 \\
133 \\
108 \\
101 \\
165\end{array}$ & $\begin{array}{l}116 \\
133 \\
111 \\
101 \\
167\end{array}$ & $\begin{array}{l}114 \\
134 \\
118 \\
101 \\
167\end{array}$ & $\begin{array}{l}107 \\
137 \\
112 \\
102 \\
174\end{array}$ & $\begin{array}{r}107 \\
123 \\
90 \\
92 \\
157\end{array}$ & $\begin{array}{l}108 \\
119 \\
103 \\
100 \\
145\end{array}$ \\
\hline 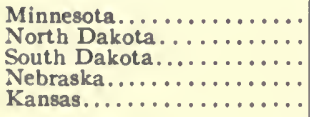 & $\begin{array}{r}104 \\
100 \\
99 \\
97 \\
102\end{array}$ & $\begin{array}{r}104 \\
105 \\
95 \\
98 \\
102\end{array}$ & $\begin{array}{l}95 \\
87 \\
89 \\
97 \\
93\end{array}$ & $\begin{array}{l}80 \\
89 \\
94\end{array}$ & $\begin{array}{r}98 \\
932 \\
85 \\
97\end{array}$ & $\begin{array}{l}70 \\
76 \\
95\end{array}$ & $\begin{array}{l}8 \dot{85} \\
82 \\
96\end{array}$ & $\begin{array}{l}80 \\
74 \\
94\end{array}$ & $\begin{array}{r}93 \\
\ddot{81} \\
\ddot{10} \dot{1}\end{array}$ & $\begin{array}{l}\ddot{65} \\
\ddot{91}\end{array}$ & $\begin{array}{l}100 \\
985 \\
90 \\
96\end{array}$ \\
\hline 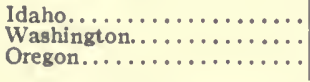 & $\begin{array}{r}93 \\
100 \\
120\end{array}$ & $\begin{array}{r}98 \\
103 \\
131\end{array}$ & $\begin{array}{r}96 \\
101 \\
131\end{array}$ & $\begin{array}{l}112 \\
114 \\
121\end{array}$ & $\begin{array}{r}95 \\
117 \\
\cdots\end{array}$ & $\begin{array}{r}91 \\
125 \\
\cdots\end{array}$ & $\begin{array}{r}91 \\
125 \\
\cdots\end{array}$ & $\begin{array}{r}86 \\
120 \\
\cdots\end{array}$ & $\begin{array}{r}83 \\
102 \\
\cdots\end{array}$ & $\begin{array}{l}102 \\
\ldots\end{array}$ & $\begin{array}{l}94 \mathrm{~b} \\
110^{b} \\
\cdots\end{array}$ \\
\hline
\end{tabular}

-Nine-year average 1923-1931. bTen-year average 1923-1932. 
period 1922-1932 for all states except Arizona, California, Nevada, New Mexico, Utah, and Wyoming. The reports are shown not as absolute amounts of seed sold at retail, but as index numbers of the amount of the current year's sales with 1923 sales as a base (Table 16).

Most of the redtop seed has been utilized in the eastern half of the United States north of the southern line of Tennessee.

\section{COMPETITION BETWEEN REDTOP AND OTHER GRASS SEEDS}

In earlier years much of the surplus redtop seed was exported, but more recently because of tariff duties and other adverse trade conditions fewer foreign shipments have been made. While the export outlet has been at least temporarily clogged, it is not correct to assume that exportation has been cut off entirely.

Local handlers of redtop seed in Illinois were interviewed in 1932 to determine the ultimate uses made of the redtop seed sold by them

Table 17.-Composition and Digestible Nutrients of Redtop and Other Hays Commonly Produced in SOUthern Illinois

(Expressed in percent)

\begin{tabular}{|c|c|c|c|c|c|c|c|c|}
\hline \multirow[b]{2}{*}{ Hay } & \multirow[b]{2}{*}{ Water } & \multirow[b]{2}{*}{ Ash } & \multirow{2}{*}{$\underset{\text { protein }}{\text { Crude }}$} & \multicolumn{2}{|c|}{ Carbohydrates } & \multirow[b]{2}{*}{ Fats } & \multicolumn{2}{|c|}{$\begin{array}{l}\text { Digestible } \\
\text { nutrients }\end{array}$} \\
\hline & & & & $\begin{array}{l}\text { Crude } \\
\text { fiber }\end{array}$ & $\begin{array}{l}\text { Nitro- } \\
\text { gen free } \\
\text { extract }\end{array}$ & & Protein & $\begin{array}{l}\text { Carbo- } \\
\text { hydrate } \\
\text { equiva- } \\
\text { lents }\end{array}$ \\
\hline $\begin{array}{l}\text { Redtop...... } \\
\text { Timothy..... } \\
\text { Minllet........ } \\
\text { Rye........... }\end{array}$ & $\begin{array}{r}8.9 \\
12.5 \\
10.3 \\
6.4\end{array}$ & $\begin{array}{l}5.2 \\
5.4 \\
7.9 \\
4.7\end{array}$ & $\begin{array}{l}7.9 \\
6.8 \\
8.8 \\
5.9\end{array}$ & $\begin{array}{l}28.6 \\
28.3 \\
27.0 \\
37.4\end{array}$ & $\begin{array}{l}47.5 \\
44.3 \\
43.3 \\
43.6\end{array}$ & $\begin{array}{l}1.9 \\
2.7 \\
2.7 \\
2.0\end{array}$ & $\begin{array}{l}4.8 \\
3.3 \\
5.1 \\
3.1\end{array}$ & $\begin{array}{l}49.1 \\
44.7 \\
48.3 \\
45.4\end{array}$ \\
\hline $\begin{array}{l}\text { Soybeans..... } \\
\text { Cowpeas.... } \\
\text { Lespedeza... } \\
\text { Red clover.. }\end{array}$ & $\begin{array}{r}8.4 \\
9.7 \\
7.9 \\
12.9\end{array}$ & $\begin{array}{r}8.9 \\
12.9 \\
6.2 \\
6.9\end{array}$ & $\begin{array}{l}15.8 \\
17.5 \\
11.9 \\
13.6\end{array}$ & $\begin{array}{l}24.3 \\
20.5 \\
28.5 \\
24.1\end{array}$ & $\begin{array}{l}38.8 \\
36.6 \\
42.7 \\
39.1\end{array}$ & $\begin{array}{l}3.8 \\
2.8 \\
2.8 \\
3.4\end{array}$ & $\begin{array}{r}11.2 \\
11.9 \\
7.9 \\
8.3\end{array}$ & $\begin{array}{l}44.0 \\
37.0 \\
44.8 \\
43.2\end{array}$ \\
\hline
\end{tabular}

- Includes the digestible crude fiber and nitrogen-f ree extract plus $21 / 4$ times the digestible fats.

from 1931 crop. On the basis of the order in which the handlers mentioned the various uses and the number of times each use was mentioned, the following rankings would seem to indicate the relative importance of the various uses:

1. Lawn-grass mixtures
2. Pasture mixtures

3. Golf-course mixtures
4. Meadows

5. Binding terraces and roadsides, and preventing erosion 
With more attention being centered on obtaining better lawns and pastures, the use of redtop seed in mixtures for these purposes has shown considerable increase during the last few years.

As a tame hay grass redtop ranks next to timothy and is an important part of nearly all hay crops in New England, New York, and Pennsylvania, as well as in much of the wet land in hilly regions of Kentucky, Tennessee, North Carolina, and Virginia. In the corn belt redtop cannot compete with timothy on the better soils. Redtop hay is not commonly ranked as the equal of timothy hay for feeding, altho analyses indicate that they are on a par with one another in composition and digestible nutrients (Table 17). Timothy hay is more palatable than redtop and deteriorates less rapidly when overripe.

Estimates of annual production and consumption on a clean-seed basis of Kentucky bluegrass and redtop seed ${ }^{13 *}$ are practically equal for the ten years 1924-1933:

Production Consumption Total

lbs. lbs. lbs.

Kentucky bluegrass seed...........98 $815000 \quad 10000000 \quad 19815000$

Redtop seed...................11 $255000 \quad 9000000 \quad 20255000$

In pasture mixtures competition between redtop and bluegrass has been of minor importance, but between redtop and timothy the competition has been somewhat keener. Less than 15 percent of the timothy seed production of the United States is produced in Illinois.

Both Kentucky bluegrass and redtop seed are important constituents of lawn-grass mixtures. For most lawn-grass mixtures Kentucky bluegrass is considered the base but may be displaced in part by the bent grasses, and for shady lawns by Poa trivialis (roughstalked meadow grass) and fescues. Redtop seed finds an important place in all such mixtures. Some rye grass is added as a companion crop, the amount being determined largely by the price at which the mixture is to sell.

A lawn-grass mixture for general purposes usually contains Kentucky bluegrass, redtop, one or more fescues, some rye grass, ${ }^{a}$ and frequently white clover. Redtop develops quickly and is fairly lasting.

Assuming viability of seed as indicated by the following percentages of germination, desirable ratios for lawn-grass mixtures for general use in the corn-belt states would be:

"Timothy is often substituted in part for rye grass. Rye grass and timothy grow quickly but are not permanent and therefore serve only as nurse crops for the permanent grasses. 


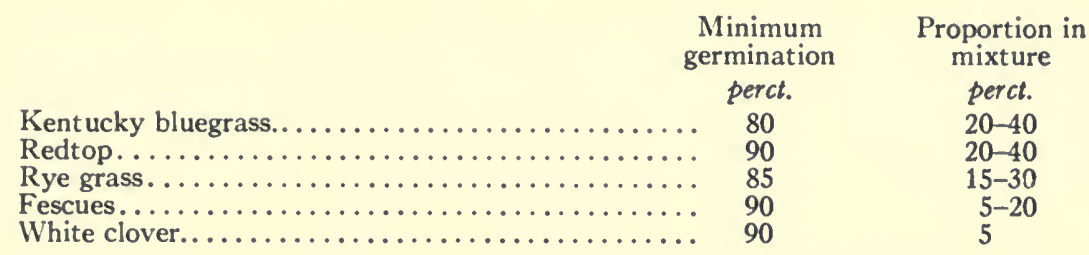

The proportion of redtop in lawn-grass mixtures should be near the upper limits, as indicated above, for use on the poorer soils, on rather acid soils, on wet soils, and on other soils if seeded late in the season.

A survey made in $1931^{13 *}$ of grass seeds used for golf courses in the United States indicated that competition of redtop seed in mixtures for this use was mainly with Kentucky bluegrass and with fescues and other bent grasses. The varieties of grass seeds used on golf courses and the percentage each was of the total thus purchased were as follows:

\begin{tabular}{|c|c|c|c|}
\hline & $\begin{array}{l}\text { Percent of } \\
\text { total }\end{array}$ & & $\begin{array}{l}\text { Percent of } \\
\text { total }\end{array}$ \\
\hline Rye grass (mostly Italian)... & 46.4 & Timothy.... & 1.3 \\
\hline Kentucky bluegrass........ & 17.7 & White clover.... & .8 \\
\hline Redtop. $\ldots \ldots \ldots \ldots \ldots \ldots$ & 13.4 & Other clovers... & .3 \\
\hline $\begin{array}{l}\text { Fescues (mainly chewings)... } \\
\text { Bent grass (other than redtop) }\end{array}$ & $\begin{array}{l}7.6 \\
5.3\end{array}$ & $\begin{array}{l}\text { Carpet grass................. } \\
\text { Poa trivialis }\end{array}$ & .3 \\
\hline 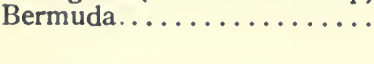 & 4.5 & $\begin{array}{l}\text { meadow grass) } \ldots \ldots \ldots \ldots \\
\text { Grass mixtures. . . . . . . . }\end{array}$ & 2.2 \\
\hline
\end{tabular}

As a binding grass on sour, poor soils that are subjected to alternate periods of excess moisture and drouth as well as to considerable tramping, redtop serves a useful purpose and large amounts are used by the highway departments of many states.

With a better understanding of the characteristics of redtop and with more attention being given to improved mixtures for various types of seeding, redtop seed consumption may be expected to show further increase.

\section{METHODS AND PROBLEMS OF MARKETING REDTOP SEED}

\section{Marketing Thru Local Dealers}

Redtop harvest for seed begins somewhere between July 8 and July 19, most frequently averaging around July 16. Threshing may begin any time after a reasonable amount of curing has taken place, that is, after ten days or more depending on the weather. It is a common practice among producers to obtain from a local dealer a supply 
of cotton bags of the kind used for seed and grain. Into these the redtop seed is placed as it comes from the threshing machine. A farmer is seldom if ever formally obligated to sell to the dealer who furnishes him with bags, altho he rarely sells elsewhere. Time of active selling by producers extends from the latter part of July thru

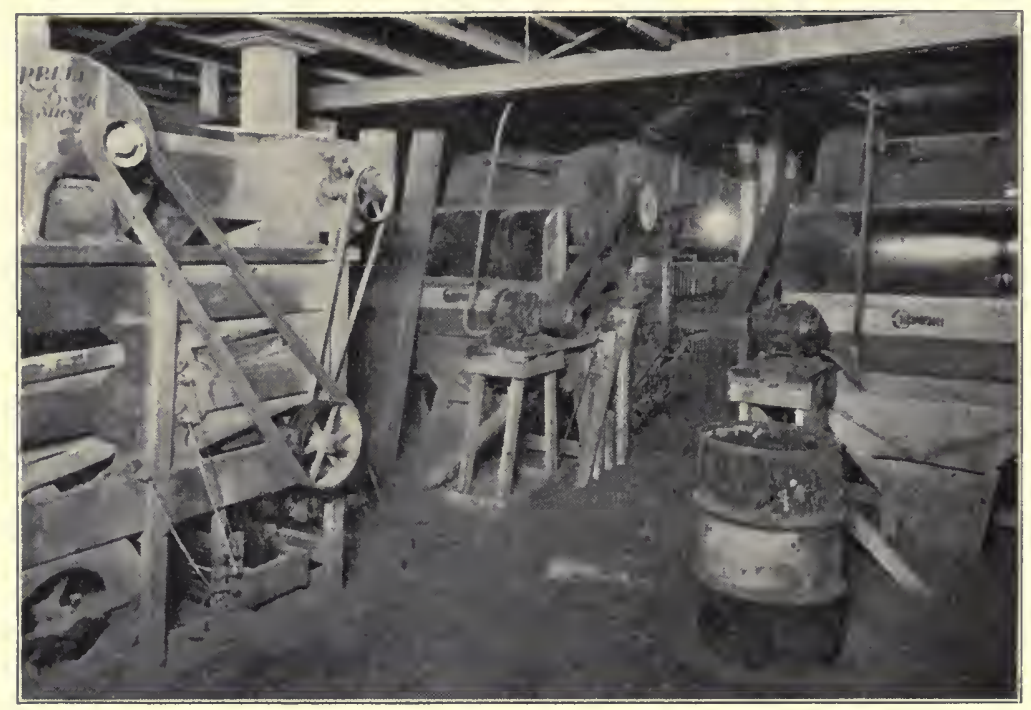

Fig. 14.-Modern Cleaning Equipment for Redtop Seed

The modern cleaning machinery and storage plant of local dealers often represents an investment of $\$ 25,000$ to $\$ 40,000$.

October, being influenced in part by progress made in threshing and in part by trend in price. The usual date of sale in 1931 was about September 1 and in 1932 August 20, according to reporting producers. Dates of sale were influenced chiefly by the personal opinions of producers concerning the possible price changes as the season advanced.

Seed is sold to local dealers on a cleaned, 90-percent purity basis, which is arrived at by cleaning a measured quantity of seed, 4 ounces in present practice, on small fanning mills differing only in size from those found in cleaning establishments. These machines are small enough to be loaded into an automobile or buggy and transported from farm to farm, altho the samples are now more often brought in by the farmer or collected by the dealer and recleaned at the plant. The machines are very accurate in their operations but can be adjusted 
to obtain slightly more or less than the standard degree of purity by changing the amount of wind directed upon the sample. After the sample is cleaned, it is weighed on a scale calibrated to indicate weight of recleaned seed in percentage of original sample. The farmer, if he desires, can see the actual value of his seed and thus receive an offer based on the market quotation. Some producers take samples of seed to be tested to two or three dealers in order to sell to the dealer who quotes the highest price per bushel on gross weight recorded at the threshing machine.

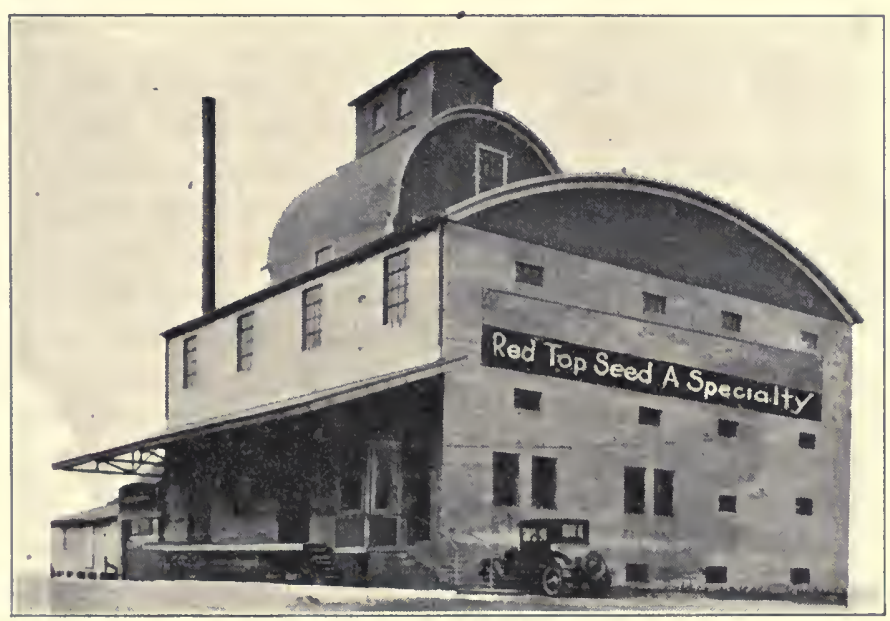

Fig. 15.-Modern Seed Plant in Southern Illinois

The building of modern seed plants in southern Illinois indicates the importance of the redtop seed industry in this part of the state.

The present method of purchase by local dealers is much more accurate and satisfactory to both parties than the earlier practice by which the dealer obtained a sample of each sackful with a sampling tube or probe, eliminated as much of the chaff as he might remove by blowing, and then on the basis of a sight examination quoted the farmer a price for his seed. Development of satisfactory cleaning machinery (Fig. 14) and the establishment of suitable grades for redtop seed entering market channels have been gradually brought about by local handlers in the Illinois redtop district ${ }^{1 *}$ and by wholesale dealers purchasing considerable quantities of seed from this district.. ${ }^{2 *}$

Seed goes to local dealers of two types: (1) dealers who act as agents for wholesale dealers and usually ship the seed to a wholesale 
establishment for further cleaning and distribution; and (2) those operating a cleaning establishment and warehouse (Fig. 15) in addition to buying and selling seed and who sell mostly to wholesale handlers, often cleaning the seed to specifications desired by the purchaser. Cleaning machinery has developed to a point where seed can easily meet high requirements in grade, purity, and germination. The redtop seed crops of 1930, 1931, and 1932 were estimated to grade as follows:

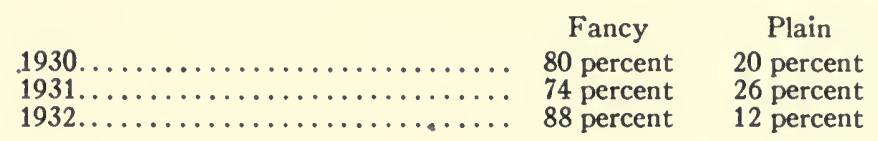

Redtop seed as it comes on the market is relatively pure and free from noxious weed seeds. The report of the Chief Seed Analyst, Illinois State Department of Agriculture, shows that for the period 1919-1929 only one-half of one percent of the samples of redtop seed in Illinois were unsalable because of noxious weed seeds. Yarrow, the most serious weed, is rather abundant in some years and difficult to remove. Red sorrel can be cleaned out but only with extra effort, usually necessitating a second cleaning of part of the seed. If reasonable attention is given to keeping meadows clean, most of the weed seed in redtop can be avoided. A part of the seed still comes to local markets with too much chaff included.

All the important local seed dealers in Illinois were interviewed between September 8 and September 15, 1932. These local dealers handled about 95 percent of the total crop purchased in 1931 and 1932. Some dealers did not report on the 1930 crop or on sales for the 1931 and 1932 crops. Handlers reported purchases, sales, and carryover as follows: ${ }^{a}$

Item

$$
1932 \quad 1931 \quad 1930
$$

(290

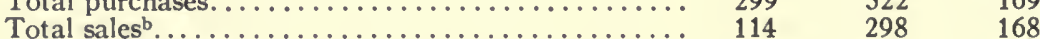

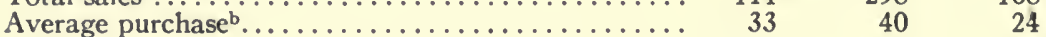

Average sale......................... $13 \quad 33 \quad 24$

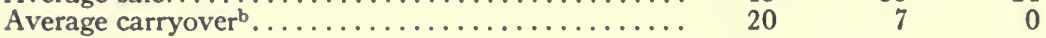

Local dealers indicated that speculators normally purchased a considerable amount of redtop seed from them and carried it over, but

"The schedules were obtained between September 8 and 15 and according to federal report, only about 70 percent of the seed had been purchased by the 15th. Sales for the crop were less complete.

'These averages are based only on establishments reporting on both purchases and sales, which represented three-fourths.of the dealers and more than half of the crop. 
that this part of the 1931 crop had been held by themselves and the 1932 crop would be similarly held. The above figures tend to bear out this statement.

Movement of crop out of growers' hands was rapid during the period 1922-1932 (Table 15, page 254). The movement of the 1931 crop from reporting handlers, in terms of carload lots, was as follows:

\begin{tabular}{|c|c|c|c|c|c|c|c|c|c|c|c|c|c|}
\hline & July & Aug. & Sept. & Oct. & Nov. & Dec. & Jan. & Feb. & Mar. & Apr. & May & June & \\
\hline & $\begin{array}{r}17 \\
7\end{array}$ & $\begin{array}{r}124 \\
42\end{array}$ & $\begin{array}{r}120 \\
85\end{array}$ & $\begin{array}{l}73 \\
76\end{array}$ & 27 & $\begin{array}{r}2 \\
12\end{array}$ & $\begin{array}{l}0 \\
7\end{array}$ & $\begin{array}{r}0 \\
12\end{array}$ & $\begin{array}{r}0 \\
13\end{array}$ & 0 & 0 & $\begin{array}{r}0 \\
10\end{array}$ & \\
\hline
\end{tabular}

Altho practically all the crop had reached local dealers by December 1, less than two-thirds had been shipped out by them at that time. About 17.5 percent of the crop was carried over by local handlers.

\section{Marketing Thru the Egyptian Seed Growers' Exchange and the Redtop Growers' Warehouse Association}

The important influence of speculators on prices paid for redtop seed caused many early producers to feel that they were not receiving a proper proportion of the final returns and that too large margins were being retained by middlemen. This belief was more firmly established in 1921 when 45 farmers in Clay county pooled 50,000 pounds of seed with a local dealer and netted two cents a pound above the average price of other local sales.

Consequently in February, 1922, 46 farmers from seven of the leading redtop seed producing counties of Illinois developed plans for organizing a cooperative seed growers' marketing association. Enough members were obtained to permit pooling operations with the 1922 crop. In October, 1923, the Egyptian Seed Growers' Exchange was organized under the Illinois Agricultural Cooperative Act. Control and management of the organization is vested in a board of thirteen directors who are elected by voting delegates from the various localities in the redtop district. These directors choose officers and have complete control of the Exchange, the only restriction being that any action of officers or agents exercised in excess of their authority is not binding upon the organization. Stock, of no par value, is issued, one share to each member. Each share carries one vote in the election of delegates.

Membership in the organization totaled 3,000 by 1930 , and the amount of seed handled from the 1931 and 1932 crops represented an important proportion of the entire redtop seed supply of the state. The physical property of the Exchange, together with that of the Warehouse Association, includes the original building plus an addition and an all-metal warehouse, 100 by 200 feet, completed in 1932 (Fig. 16). 
The Warehouse Association, a subsidiary organization of the Seed Exchange, owns and operates a government-bonded warehouse which receives seed as delivered for the account of the producer. The warehouse superintendent tests the seed and issues to the Exchange a receipt based on the amount of "fancy" seed contained in a sample. The

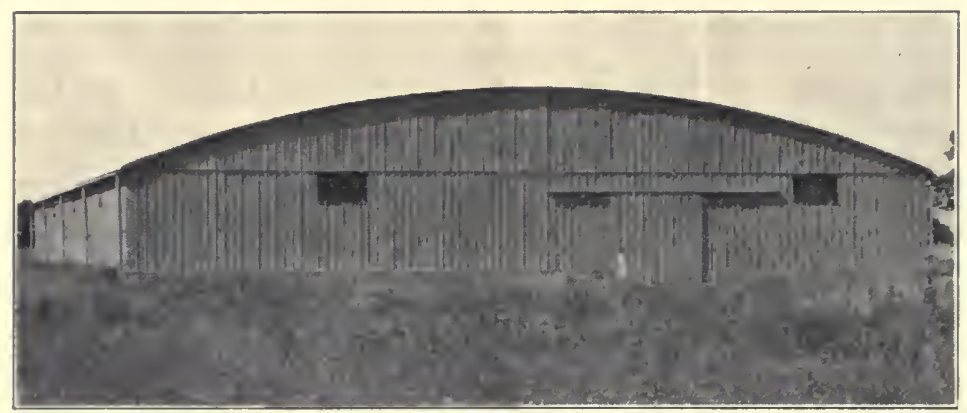

Fig. 16.-New Fireproof Warehouse of the Egyptiax Seed Growers' Association

The fireproof warehouse shown above provides economical and safe storage for redtop seed on a large scale.

Exchange then uses this receipt as collateral in securing the loan of necessary funds for operation and for paying the amount advanced to producers on delivery of seed. The balance is paid to producers on disposition of the entire crop.

The policy of the Exchange is to advance to the producer at time of delivery a price per pound for "fancy" seed based on the manager's judgment as to what is a safe figure, considering cost of handling, loan value, and probable market price of the seed. After the seed is cleaned and graded, the policy of the Exchange has been to sell the seed on the open market direct to wholesale dealers and jobbers as demand and supply conditions seem to warrant. In the main, local handlers and the Exchange dispose of their seed to the same class of dealers. Approximately 60 percent of the seed that leaves local handlers is disposed of in carload lots and about 35 percent in less than carload lots. The other 5 percent goes back to local farmers for new plantings.

\section{Marketing by Wholesale Dealers}

Wholesale dealers handle redtop along with other seed and dispose of the bulk of it in grass-seed mixtures, altho a considerable amount is sold as straight redtop seed for use in southern states. Much of the 
seed is disposed of in specially labeled bags or packages. Cleaning is seldom performed by wholesale dealers except where they buy direct from producers thru local representatives. In these instances the seed is assembled and usually cleaned at the central plant (Fig. 17).

Distribution extends over a large territory for each wholesale dealer, as his retail handlers are both numerous and widely distrib-

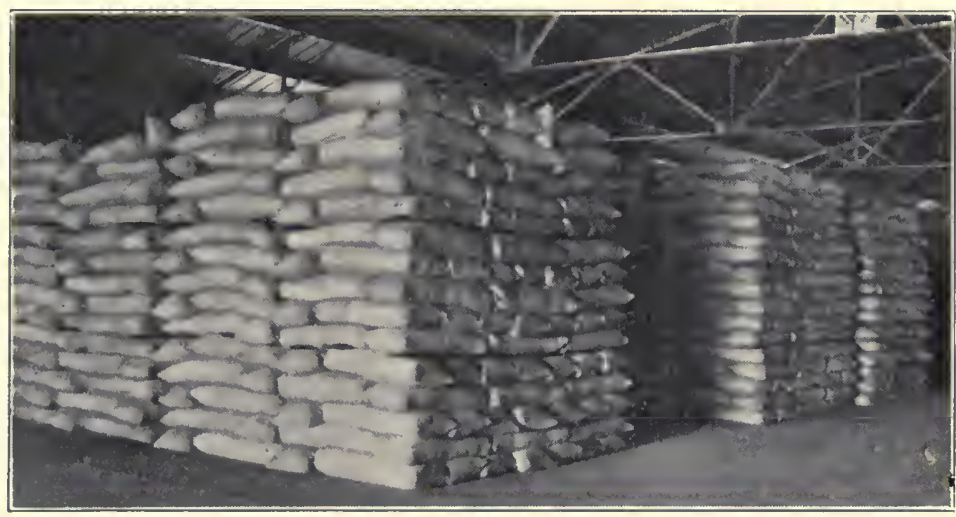

Fig. 17.-Storage of Cleaned Redtor Seed

Redtop seed sold in bulk is often sacked after cleaning and stored by the cleaning establishment, as shown above.

uted. The territory served by each wholesale dealer usually overlaps that of other dealers. About twenty wholesale dealers purchase the bulk of seed from local handlers in Illinois. Distribution is thru both jobbers and retail handlers.

\section{Retail Marketing}

Retail distribution of grass seeds is made by numerous agencies in each community. Seed firms, hardware stores, florist shops, feed stores, and general grocery stores are the usual local distributing agents.

Retail sales are made both in mixtures and in bulk. In areas in which redtop is grown alone to considerable extent, the proportion of redtop seed sold in bulk is high even when used in seeding with other grasses. Some of the larger retail handlers of seed make up their own mixtures but the majority either have the mixing done for them by wholesale firms specializing in this phase of the business or purchase seed mixtures thru regular channels. Most dealers supplying lawngrass seed mixtures have a standard list of brands meeting various 
types of lawn needs and price requirements of the consuming public. The Illinois seed law requires each sack containing seed mixtures to carry an analysis so that the consumer may know what he is buying.

\section{Recent Efforts to Stabilize Redtop Seed Marketing}

The price of redtop seed practically doubled in 1925 and 1926 compared with 1924, owing apparently to speculative control of redtop seed supplies. A similar price change occurred beginning in the spring of 1933.

Demands for more far-reaching and systematic methods of establishing and maintaining balance between production and consumption of redtop seed reached concrete expression in a proposed marketing agreement for the redtop seed industry made under the Agricultural Adjustment Act approved May 12, 1933. It became clear at the hearing held March 9, 1934, with reference to this proposal that had redtop been included in the list of basic agricultural commodities provided in the Agricultural Adjustment Act, problems of redtop marketing might have been more easily solved. There has been some question as to the extent to which dealers in a commodity that lacked the status of a basic agricultural commodity could organize for market control.

In the absence of further federal legislation which would broaden the list of basic agricultural commodities so as to include redtop seed, it seems doubtful that any satisfactory program of production control is to be expected. It is not likely that Illinois would be joined by other states in a treaty to control marketing of a commodity the production of which is as concentrated in one state as is redtop seed production in Illinois. Purely voluntary agreements on the part of producers and dealers could not be expected easily to attain the degree of control which has been attempted for basic agricultural commodities.

In May, 1934, the Federal Surplus Relief Corporation, following suggestions by sponsors of the sale of redtop and other seeds that $9,000,000$ pounds of redtop seed and somewhat larger amounts of Kentucky bluegrass and lespedeza seed should be acquired by this federal agency, had offers of $5,500,000$ pounds of redtop seed at prices ranging mostly from 8 to $91 / 2$ cents a pound for seed of a purity of 90 percent or better and of a germination of 85 percent or better. The extent to which these stocks of seed will be accumulated in federal hands prior to utilization on erosion and other projects supported by federal and other public funds was not published at the time the specifications were released for the use of those who were tendering supplies. 


\section{PRICES OF REDTOP SEED}

\section{Producer Prices}

Prices received by producers for redtop seed vary greatly from season to season. Redtop seed prices reached a low of 3.4 cents a pound for recleaned seed in 1932 and during four years of the period 1907-1932 reached annual averages as high as 22 cents (Fig. 18).

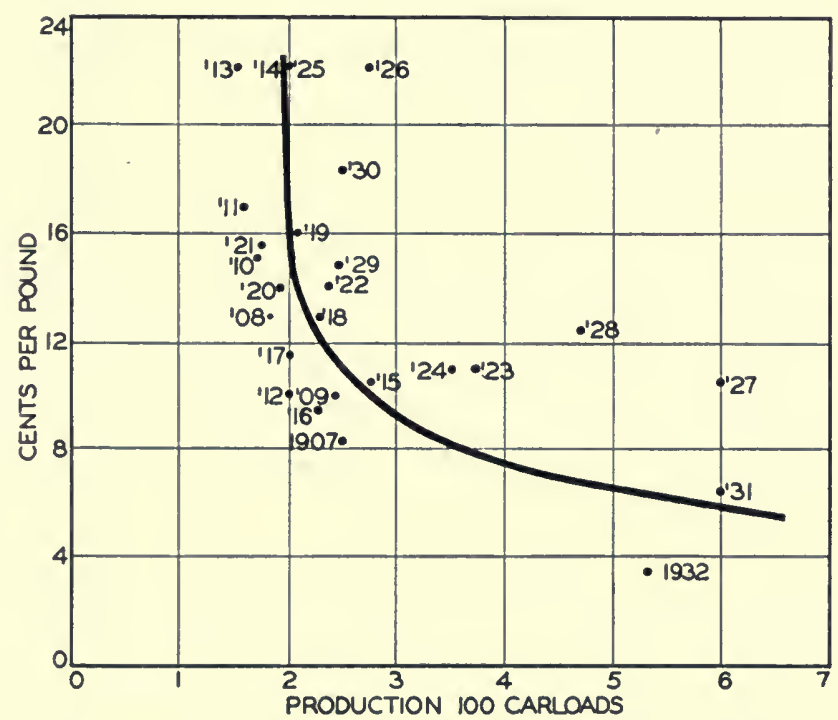

Fig. 18.-Production of Redtop Seed in the United States for the Crop Years 1907-1932, and Prices Paid to Producers

Price is influenced somewhat by production but other factors are important, as is indicated by the wide spread in price in years when annual production was around 200 carloads.

The average price for the ten-year period 1923-1932 was about 13 cents a pound (Table 18). Prices as a rule have not been well established by July 15. Prices for the months of August, September, and October are generally well established, however, as most of the crop is sold by November 15. Average prices by months have usually varied $1 / 2$ to $11 / 2$ cents a pound during August, September, and October of a single year, but have shown a spread of as much as 4 cents. Prices paid to producers are usually influenced by the size of the current crop. Some large crops of recent years, however, were not reflected in price as accurately as the other crops thruout the period. 
Table 18.-Prices Paid Producers for "Fancy" Redtop Seed, United States, BY Months, July to November

(Cents per pound)

\begin{tabular}{|c|c|c|c|c|c|c|}
\hline Year & July 15* & Aug. 15 & Sept. 15 & Oct. 15 & Nov. 15 & Average \\
\hline $1922 \ldots \ldots \ldots \ldots \ldots \ldots \ldots$ & 14 & 15 & 14.5 & 13.5 & $\ldots$ & 14 \\
\hline 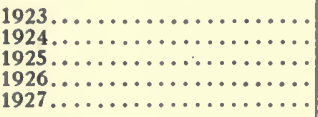 & $\begin{array}{l}11 \\
11 \\
17 \\
18 \\
13\end{array}$ & $\begin{array}{l}14 \\
11 \\
18.5 \\
21 \\
10.5\end{array}$ & $\begin{array}{l}11 \\
10 \\
22.5 \\
22.75 \\
9.5\end{array}$ & $\begin{array}{l}11 \\
10 \\
22.5 \\
21 \\
10.25\end{array}$ & $\begin{array}{l}\cdots \\
\cdots \\
10.25\end{array}$ & $\begin{array}{l}11 \\
11 \\
22 \\
22 \\
10.5\end{array}$ \\
\hline 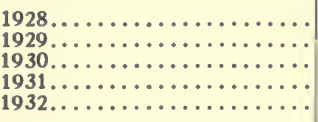 & $\begin{array}{r}11 \\
14 \\
16 \\
10 \\
5\end{array}$ & $\begin{array}{l}11 \\
15 \\
18.5 \\
7.25 \\
3.3\end{array}$ & $\begin{array}{l}12.5 \\
14 \\
18 \\
6.33 \\
3.5\end{array}$ & $\begin{array}{l}13 \\
14.25 \\
\cdots \cdots \\
\ddot{3} .5\end{array}$ & $\begin{array}{l}12.5 \\
\cdots \\
\cdots .75 \\
\cdots\end{array}$ & $\begin{array}{l}12.5 \\
14.25 \\
18.25 \\
6.5 \\
3.5\end{array}$ \\
\hline Average $1923-1932 . \ldots \ldots$ & 12.6 & 13.0 & 13.0 & 13.2 & $\ldots$ & 12.9 \\
\hline
\end{tabular}

July $15,1921=15 \notin$ per pound.

Comparison of the changes in prices paid to producers with changes in total supply and disappearance indicates a closer adjustment of prices to supply than to disappearance (Fig. 13, page 253), mainly because of greater elasticity in supply. The apparent failure to show the usual inverse relation between supply and price for the 1928 crop was due in part to a decided response of producer prices to increased supply in the previous year.

\section{Wholesale Prices}

Wholesale price quotations for redtop seed are shown weekly during the months of January thru May at Chicago, Louisville, St. Louis,

Table 19.-Average Wholesale Selling Prices of Redtop Seed at LEADING MARKETS bY CROP YEARS

(Cents per pound)

\begin{tabular}{|c|c|c|c|c|c|c|c|}
\hline Crop year & Chicago & $\begin{array}{l}\text { Louis- } \\
\text { ville }\end{array}$ & St. Louis & $\begin{array}{c}\text { Kansas } \\
\text { City }\end{array}$ & $\begin{array}{l}\text { Balti- } \\
\text { more }\end{array}$ & $\begin{array}{l}\text { New } \\
\text { York }\end{array}$ & $\begin{array}{l}\text { Minne- } \\
\text { apolis }\end{array}$ \\
\hline 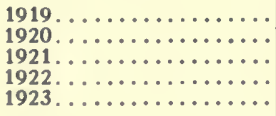 & $\begin{array}{l}17.20 \\
13.05 \\
22.65 \\
18.70 \\
13.65\end{array}$ & $\begin{array}{l}19.70 \\
14.95 \\
23.90 \\
18.75 \\
13.90\end{array}$ & $\begin{array}{l}19.85 \\
13.60 \\
23.90 \\
19.80 \\
14.60\end{array}$ & $\begin{array}{l}20.00 \\
14.50 \\
25.15 \\
21.50 \\
15.20\end{array}$ & $\begin{array}{l}18.55 \\
13.80 \\
22.45 \\
19.65 \\
14.20\end{array}$ & $\begin{array}{l}18.45 \\
14.00 \\
23.55 \\
19.30 \\
14.20\end{array}$ & $\begin{array}{l}21.10 \\
14.85 \\
24.35 \\
20.50 \\
15.35\end{array}$ \\
\hline $\begin{array}{l}1924 \ldots \ldots \cdots \cdots \cdots \\
1925 \ldots \ldots \cdots \cdots \\
1926 \ldots \ldots \cdots \cdots \\
1927 \ldots \ldots \cdots \cdots \\
1928 \ldots \ldots \cdots\end{array}$ & $\begin{array}{l}14.40 \\
31.20 \\
25.30 \\
13.10 \\
14.55\end{array}$ & $\begin{array}{l}14.15 \\
31.50 \\
24.85 \\
13.55 \\
15.20\end{array}$ & $\begin{array}{l}13.95 \\
31.15 \\
26.20 \\
13.65 \\
14.75\end{array}$ & $\begin{array}{l}15.00 \\
31.05 \\
24.30 \\
13.95 \\
15.45\end{array}$ & $\begin{array}{l}14.20 \\
32.60 \\
25.60 \\
14.00 \\
15.55\end{array}$ & $\begin{array}{l}14.50 \\
32.25 \\
25.65 \\
13.95 \\
15.50\end{array}$ & $\begin{array}{l}16.00 \\
32.70 \\
27.00 \\
15.45 \\
16.00\end{array}$ \\
\hline $\begin{array}{l}1929 \ldots \ldots \ldots \ldots \ldots \ldots \ldots \\
1930 \ldots \ldots \ldots \ldots \ldots \ldots \\
1931 \ldots \ldots \ldots \ldots \ldots \ldots \\
1932 \ldots \ldots \ldots \ldots \ldots\end{array}$ & $\begin{array}{r}16.45 \\
24.20 \\
8.70 \\
5.30\end{array}$ & $\begin{array}{r}16.55 \\
25.30 \\
8.50 \\
5.20\end{array}$ & $\begin{array}{r}16.85 \\
24.70 \\
9.30 \\
5.25\end{array}$ & $\begin{array}{r}17.50 \\
24.80 \\
10.00 \\
5.85\end{array}$ & $\begin{array}{r}17.05 \\
24.95 \\
9.35 \\
5.65\end{array}$ & $\begin{array}{r}17.05 \\
26.50 \\
9.65 \\
5.55\end{array}$ & $\begin{array}{r}18.45 \\
25.80 \\
11.20 \\
6.65\end{array}$ \\
\hline Average............. & 17.05 & 17.55 & 17.70 & 18.15 & 17.70 & 17.85 & 18.95 \\
\hline
\end{tabular}


Table 20.-Average Wholesale Selling Prices of Redtop Seed at Chicago, January to May

(Cents per pound)

\begin{tabular}{|c|c|c|c|c|c|c|}
\hline Year & Jan. & Feb. & Mar. & Apr. & May & Average \\
\hline 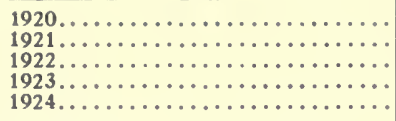 & $\begin{array}{l}18.75 \\
12.25 \\
22.90 \\
20.00 \\
13.25\end{array}$ & $\begin{array}{l}18.25 \\
12.05 \\
23.25 \\
19.65 \\
13.40\end{array}$ & $\begin{array}{l}17.40 \\
13.35 \\
23.35 \\
18.50 \\
13.70\end{array}$ & $\begin{array}{l}16.40 \\
13.75 \\
22.20 \\
17.80 \\
13.80\end{array}$ & $\begin{array}{l}15.10 \\
13.95 \\
21.65 \\
17.50 \\
14.00\end{array}$ & $\begin{array}{l}17.20 \\
13.05 \\
22.65 \\
18.70 \\
13.65\end{array}$ \\
\hline 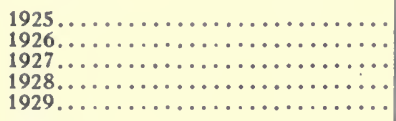 & $\begin{array}{l}14.20 \\
31.70 \\
24.30 \\
12.45 \\
14.95\end{array}$ & $\begin{array}{l}14.30 \\
31.65 \\
25.85 \\
12.30 \\
14.95\end{array}$ & $\begin{array}{l}14.35 \\
31.65 \\
25.80 \\
12.35 \\
14.85\end{array}$ & $\begin{array}{l}14.60 \\
31.55 \\
25.40 \\
13.60 \\
14.30\end{array}$ & $\begin{array}{l}14.50 \\
29.50 \\
25.10 \\
14.80 \\
13.80\end{array}$ & $\begin{array}{l}14.40 \\
31.20 \\
25.30 \\
13.10 \\
14.55\end{array}$ \\
\hline 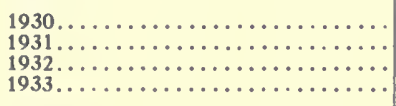 & $\begin{array}{r}15.80 \\
23.70 \\
9.00 \\
4.50\end{array}$ & $\begin{array}{r}15.80 \\
24.00 \\
8.95 \\
4.50\end{array}$ & $\begin{array}{r}16.10 \\
24.00 \\
8.50 \\
4.50\end{array}$ & $\begin{array}{r}17.10 \\
24.75 \\
8.50 \\
5.75\end{array}$ & $\begin{array}{r}17.60 \\
24.50 \\
8.60 \\
7.10\end{array}$ & $\begin{array}{r}16.45 \\
24.20 \\
8.70 \\
5.30\end{array}$ \\
\hline Average..$\ldots \ldots \ldots \ldots \ldots \ldots$ & 17.00 & 17.05 & 17.05 & 17.10 & 17.00 & 17.05 \\
\hline
\end{tabular}

Baltimore, New York, Minneapolis, and Kansas City. Prices have usually been lowest at the markets nearest the source of farm supply (Table 19). For the ten-year period 1923-1932 these cities ranked as follows in yearly average price quotations for redtop seed, from low to high: Chicago, Louisville, St. Louis, Baltimore, New York, Kansas City, Minneapolis. The difference between the highest and lowest average was $\$ 1.15$ per 100 pounds of seed.

Comparisons of quotations at the two markets, Chicago and Louisville, show that average prices have been consistently higher at Louisville, only 4 years out of the 14 showing otherwise (Tables 20 and

Table 21.-Average Wholesale Selling Prices of Redtop Seed at LOUISVILle, JANUARY TO MAY

(Cents per pound)

\begin{tabular}{|c|c|c|c|c|c|c|}
\hline Year & Jan. & Feb. & Mar. & Apr. & May & Average \\
\hline 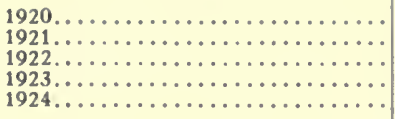 & $\begin{array}{l}21.90 \\
13.65 \\
24.45 \\
20.00 \\
13.75\end{array}$ & $\begin{array}{l}21.25 \\
14.40 \\
25.00 \\
20.00 \\
14.00\end{array}$ & $\begin{array}{l}19 \cdot 25 \\
15.15 \\
25.35 \\
18.50 \\
13.80\end{array}$ & $\begin{array}{l}18.65 \\
15.00 \\
23.90 \\
17.80 \\
14.00\end{array}$ & $\begin{array}{l}17.40 \\
16.50 \\
22.70 \\
17.50 \\
14.00\end{array}$ & $\begin{array}{l}19.70 \\
14.95 \\
23.90 \\
18.75 \\
13.90\end{array}$ \\
\hline 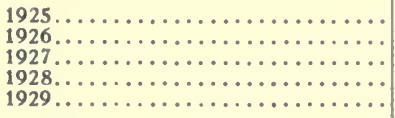 & $\begin{array}{l}14.00 \\
31.90 \\
24.00 \\
13.00 \\
15.80\end{array}$ & $\begin{array}{l}14.35 \\
31.65 \\
24.90 \\
12.80 \\
15.85\end{array}$ & $\begin{array}{l}14.45 \\
31.50 \\
25.35 \\
12.50 \\
15.65\end{array}$ & $\begin{array}{l}14.00 \\
31.35 \\
25.00 \\
13.60 \\
14.50\end{array}$ & $\begin{array}{l}14.00 \\
31.10 \\
25.00 \\
15.90 \\
14.30\end{array}$ & $\begin{array}{l}14.15 \\
31.50 \\
24.85 \\
13.55 \\
15.20\end{array}$ \\
\hline $\begin{array}{l}1930 \ldots \ldots \ldots \ldots \ldots \ldots \ldots \ldots \ldots \ldots \\
1931 \ldots \ldots \ldots \ldots \\
1932 \ldots \ldots \ldots \ldots \\
1933 \ldots \ldots \ldots \ldots\end{array}$ & $\begin{array}{r}16.05 \\
25.00 \\
9.35 \\
5.05\end{array}$ & $\begin{array}{r}16.50 \\
25.40 \\
8.55 \\
4.50\end{array}$ & $\begin{array}{r}16.20 \\
25.75 \\
8.45 \\
4.50\end{array}$ & $\begin{array}{r}16.55 \\
25.45 \\
8.15 \\
5.30\end{array}$ & $\begin{array}{r}17.40 \\
24.95 \\
8.00 \\
6.65\end{array}$ & $\begin{array}{r}16.55 \\
25.30 \\
8.50 \\
5.20\end{array}$ \\
\hline 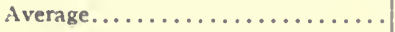 & 17.70 & 17.80 & 17.60 & 17.40 & 17.55 & 17.60 \\
\hline
\end{tabular}


21). The average amount of difference per 100 pounds in favor of Louisville by months was as follows:

$\begin{array}{cccccc}\text { January } & \text { February } & \text { March } & \text { April } & \text { May } & \text { Average } \\ .70 & .75 & .55 & .30 & .55 & .55\end{array}$

\section{Retail Prices}

Retail prices have usually been lowest in states producing large supplies of redtop and bluegrass. According to average annual retail prices of redtop seed for the 1923-1932 period, the following ten states fall into high and low groups as indicated, with an average difference of $\$ 3.55$ per 100 pounds for the two groups (Table 22):

\begin{tabular}{llll}
\multicolumn{2}{c}{ High group } & \multicolumn{2}{c}{ Low group } \\
Ohio & New York & Tennessee & Kansas \\
Pennsylvania & Iowa & Kentucky & Illinois \\
Indiana & & Missouri &
\end{tabular}

The range of difference in average yearly prices was 60 cents per 100 pounds, or less than 3 percent in the states of the lower price

Table 22.-Average Retail Prices Paid for "Fancy" Redtop Seed in Selected States

(Cents per pound)

\begin{tabular}{|c|c|c|c|c|c|c|c|c|c|c|}
\hline Crop year & Ill. & Ind. & Ohio & Ky. & Tenn. & N.Y. & Penn. & lowa & $\underset{\mathrm{ri}}{\text { Missou- }}$ & Kans. \\
\hline $\begin{array}{l}1923 \ldots \ldots \ldots \\
1924 \ldots \ldots \ldots \ldots \\
1925 \ldots \ldots \ldots \ldots \\
1926 \ldots \ldots \ldots \\
1927 \ldots \ldots \ldots\end{array}$ & $\begin{array}{l}17.70 \\
18.35 \\
33.20 \\
29.50 \\
18.65\end{array}$ & $\begin{array}{l}21.25 \\
19.95 \\
38.30 \\
35.25 \\
21.35\end{array}$ & $\begin{array}{l}21.15 \\
22.60 \\
38.80 \\
35.50 \\
23.55\end{array}$ & $\begin{array}{l}17.05 \\
17.15 \\
34.80 \\
31.15 \\
16.90\end{array}$ & $\begin{array}{l}17.70 \\
17.90 \\
33.00 \\
30.70 \\
16.75\end{array}$ & $\begin{array}{l}21.10 \\
21.20 \\
36.00 \\
34.80 \\
20.00\end{array}$ & $\begin{array}{l}18.20 \\
20.90 \\
37.25 \\
36.00 \\
21.80\end{array}$ & $\begin{array}{l}19.75 \\
19.40 \\
33.70 \\
31.85 \\
19.40\end{array}$ & $\begin{array}{l}18.25 \\
17.65 \\
33.05 \\
30.35 \\
17.05\end{array}$ & $\begin{array}{l}18.25 \\
16.80 \\
33.75 \\
30.25 \\
18.30\end{array}$ \\
\hline $\begin{array}{l}1928 \ldots \ldots \ldots \\
1929 \ldots \ldots \ldots \\
1930 \ldots \ldots \ldots \\
1931 \ldots \ldots \ldots \\
1932 \ldots \ldots \ldots\end{array}$ & $\begin{array}{r}18.75 \\
21.10 \\
27.20 \\
12.80 \\
7.90\end{array}$ & $\begin{array}{r}22.35 \\
23.05 \\
30.40 \\
13.95 \\
9.10\end{array}$ & $\begin{array}{l}24.40 \\
23.50 \\
31.90 \\
17.00 \\
10.00\end{array}$ & $\begin{array}{r}18.55 \\
19.00 \\
26.65 \\
11.40 \\
6.90\end{array}$ & $\begin{array}{r}18.10 \\
19.30 \\
26.20 \\
12.10 \\
7.20\end{array}$ & $\begin{array}{l}21.60 \\
23.40 \\
30.60 \\
14.60 \\
10.00\end{array}$ & $\begin{array}{l}22.50 \\
24.40 \\
34.00 \\
17.10 \\
11.15\end{array}$ & $\begin{array}{r}21.90 \\
24.20 \\
29.00 \\
14.90 \\
9.50\end{array}$ & $\begin{array}{r}18.10 \\
19.55 \\
26.90 \\
12.20 \\
7.20\end{array}$ & $\begin{array}{r}18.05 \\
20.95 \\
25.60 \\
12.95 \\
7.85\end{array}$ \\
\hline Average.... & 20.50 & 23.50 & 24.85 & 20.00 & 19.90 & 23.35 & 24.35 & 22.35 & 20.05 & 20.30 \\
\hline
\end{tabular}

group, and $\$ 2.50$ per 100 pounds, or nearly 11 percent, in those of the higher price group. These price quotations were based on available monthly figures by states from January thru May.

When an average of wholesale prices at Chicago and Louisville is used as representative for Illinois, the spread between producer and wholesale prices of redtop seed and that between wholesale and retail prices are indicated to have been nearly equal during the ten-year period 1923-1932. The spread was $\$ 3.65$ per 100 pounds between producer and wholesale prices and $\$ 3.70$ between wholesale and retail prices (Table 23). 
Table 23.-Average Prices of Redtop Seed in Illinois Compared With Same Prices Adjusted for Purchasing Power

(Cents per pound)

\begin{tabular}{|c|c|c|c|c|c|c|c|c|c|}
\hline \multirow{2}{*}{$\begin{array}{l}\text { Crop } \\
\text { year }\end{array}$} & \multicolumn{3}{|c|}{ Producer } & \multicolumn{3}{|c|}{ Wholesale prices } & \multicolumn{3}{|c|}{ Retail prices } \\
\hline & Actual & $\underset{\text { ed }}{\text { Adjust- }}$ & $\begin{array}{l}\text { Differ- } \\
\text { ence }\end{array}$ & Actual & $\begin{array}{l}\text { Adjust- } \\
\text { ed }\end{array}$ & $\begin{array}{c}\text { Differ- } \\
\text { ence }\end{array}$ & Actual & $\begin{array}{c}\text { Adjust- } \\
\text { ed }\end{array}$ & $\begin{array}{c}\text { Differ- } \\
\text { ence }\end{array}$ \\
\hline $\begin{array}{l}1922 \ldots \ldots \\
1923 \ldots \ldots \\
1924 \ldots \ldots \\
1925 \ldots \ldots \\
1926 \ldots \ldots\end{array}$ & $\begin{array}{l}14 \\
11 \\
11 \\
22 \\
22\end{array}$ & $\begin{array}{l}14.1 \\
11.1 \\
11.3 \\
21.2 \\
22.2\end{array}$ & $\begin{array}{r}.1 \\
.1 \\
. .2 \\
-.8 \\
.2\end{array}$ & $\begin{array}{l}18.70 \\
13.80 \\
14.30 \\
31.35 \\
25.10\end{array}$ & $\begin{array}{l}18.1 \\
14.1 \\
13.9 \\
30.9 \\
26.4\end{array}$ & $\begin{array}{r}-.60 \\
. .30 \\
-.40 \\
.45 \\
1.30\end{array}$ & $\begin{array}{l}23.60^{\mathrm{b}} \\
17.70 \\
18.35 \\
33.20 \\
29.50\end{array}$ & $\begin{array}{l}22.8^{b} \\
18.1 \\
17.8 \\
32.9 \\
31.2\end{array}$ & $\begin{array}{r}-.80 \\
-.40 \\
-.55 \\
-.30 \\
1.70\end{array}$ \\
\hline $\begin{array}{l}1927 \ldots \ldots \\
1928 \ldots \ldots \\
1929 \ldots \ldots \\
1930 \ldots \ldots \\
1931 \ldots \ldots\end{array}$ & $\begin{array}{c}10.5 \\
12.5 \\
14.25 \\
18.25 \\
6.5 \\
3.4\end{array}$ & $\begin{array}{r}10.9 \\
12.7 \\
15.0 \\
22.0 \\
9.1 \\
5.3\end{array}$ & $\begin{array}{l}.4 \\
.2 \\
.75 \\
3.75 \\
2.6 \\
1.9\end{array}$ & $\begin{array}{r}13.30 \\
14.90 \\
16.50 \\
24.75 \\
8.60 \\
5.25\end{array}$ & $\begin{array}{r}13.7 \\
15.4 \\
18.1 \\
32.6 \\
13.1 \\
8.6\end{array}$ & $\begin{array}{r}.40 \\
.50 \\
1.60 \\
7.85 \\
4.50 \\
3.35\end{array}$ & $\begin{array}{r}18.65 \\
18.75 \\
21.10 \\
27.20 \\
12.80 \\
7.90\end{array}$ & $\begin{array}{l}19.2 \\
19.5 \\
23.3 \\
36.2 \\
19.5 \\
13.0\end{array}$ & $\begin{array}{r}.55 \\
.75 \\
2.20 \\
9.00 \\
6.70 \\
5.10\end{array}$ \\
\hline Average... & 13.20 & 14.1 & .9 & 16.95 & 18.6 & 1.65 & 20.80 & 23.0 & 1.80 \\
\hline
\end{tabular}

- Each price series was adjusted by dividing the actual price by the average of the U. S. Bureau of Labor Statistics index number of wholesale prices for all commodities, 1926 base, for the months covered by each price series. bAverage of Kentucky, Ohio, Indiana, Illinois, and Michigan.

When prices are expressed in dollars of 1926 purchasing power, the spread is increased in both instances, being $\$ 4.60$ and $\$ 4.40$ per 100 pounds. Increase in purchasing power has been noticeable mainly since 1926. Comparison of figures from year to year shows that the three series of prices-producer, wholesale, and retail-have consistently moved in the same direction. Producer prices, however, have

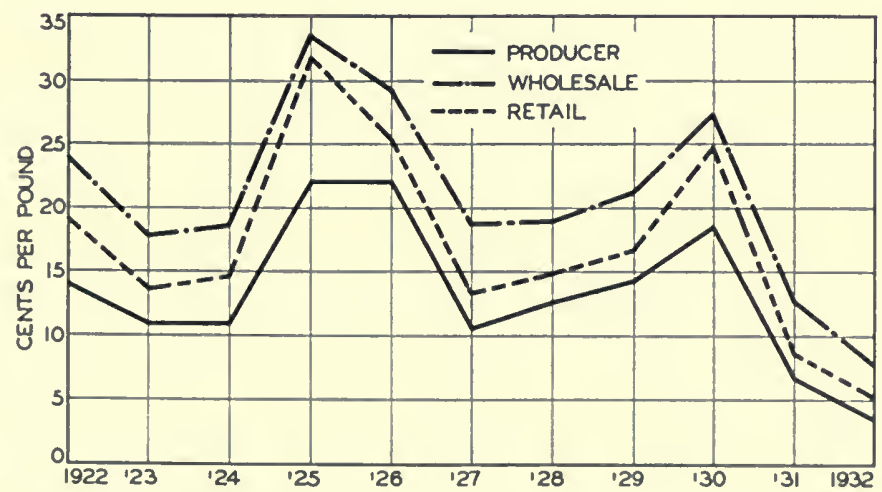

Fig. 19.-Prices Paid for Redtop Seed to Producers, to Wholesale Dealers, and to Retail Dealers in the Crop Years 1922-1932

Spreads between producer and wholesale prices and between wholesale and retail prices have remained fairly constant. Slight variations have been due mainly to producer prices lagging behind wholesale and retail prices on the upward swings and of retail prices lagging behind producer and wholesale prices on the downward swings. 
gone up less in proportion than the others in years of large price increases, as indicated by 1925 and 1930 prices; while retail prices have moved down less rapidly from high peaks than either of the other series (Fig. 19).

\section{Prices and Quantities}

Comparison of producer, wholesale, and retail prices of redtop seed with production, total supply (production and carryover), and disappearance indicates that there was little difference in the reaction of prices of the producer, wholesale, and retail series to the various

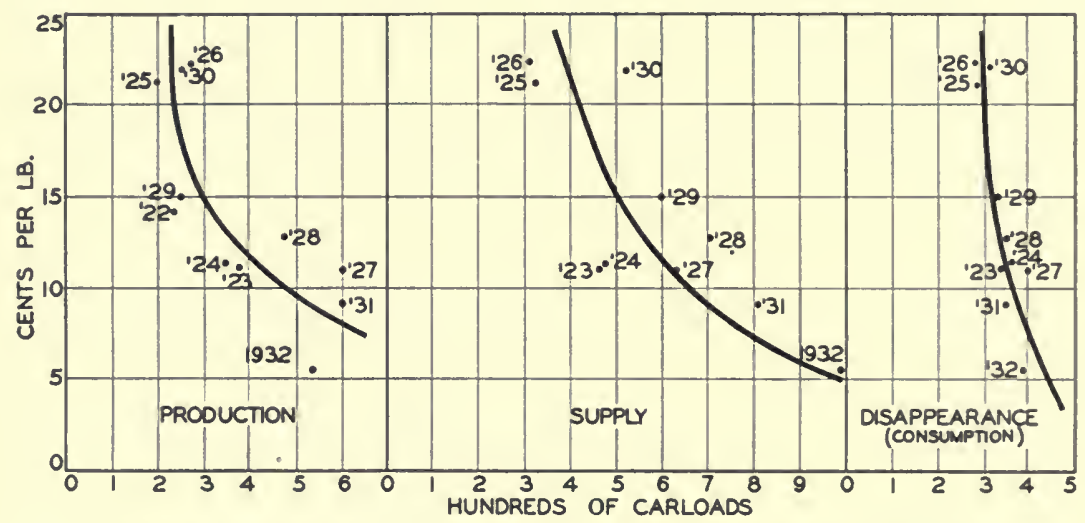

Fig. 20.-Production, Total Supply, and Disappearance of Redtop

Seed in Relation to Adjusted Prices Paid to Producers in the United States, Crop Years 1922-1932

Redtop seed prices respond most to supply quantities and least to disappearance or consumption quantities. Of the quantities making up supply, production has influenced price more than carryover.

quantities except for somewhat less sensitiveness of producer prices to changes in annual amounts. The comparatively slight sensitiveness displayed by producer prices in years of smaller crops is especially to be noted (Fig. 20).

Prices in all three series showed decided reactions to all three quantity series. Annual disappearances have been least elastic in relation to price differences, and production amounts most elastic. It would appear that prices can be forecast best thru the total supply available for the coming season. On the other hand, demand has responded only slightly to price changes the following season. In all cases prices have responded less to a given change in supply at the 
surplus end of a period of accumulation than at other times. It is possible to account for the wide range of variation in price over several years largely on the basis of the inelasticity of demand for the product, regardless of price, and the small amount of consumption usually required by various individuals.

Prices of other grass seeds, particularly bluegrass and timothy, which more or less reflect their supplies, also affect somewhat the prices of redtop seed (Fig. 21). Another factor influencing redtop

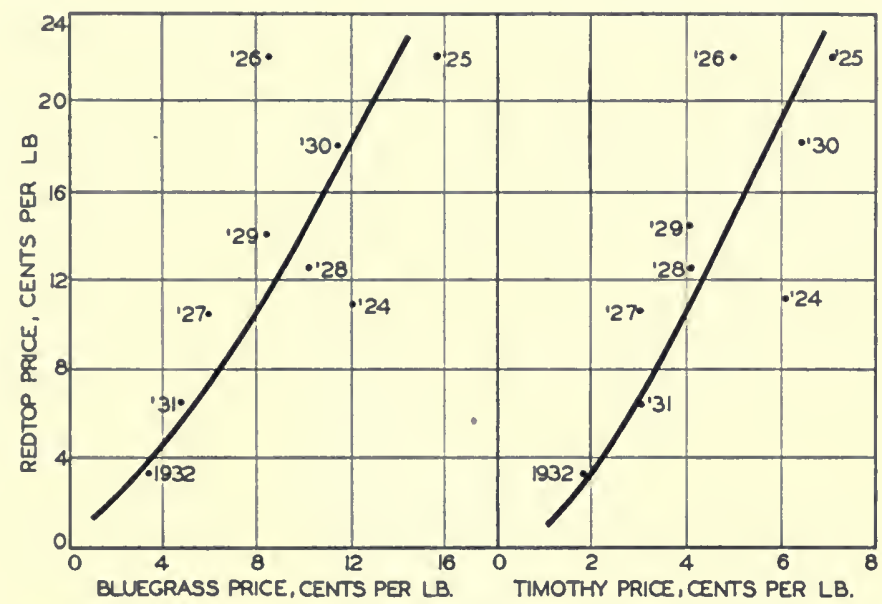

Fig. 21.-Prices Paid to Producers for Redtop Seed in Relation to Corresponding Prices for Bluegrass and Timothy Seed, Crop Years 1924-1932

Prices of both bluegrass and timothy seed show some correlation with those of redtop seed. The prices of these two grass seeds have exerted similar influences on redtop seed prices.

seed prices has been the export situation since about 1922. Import duties have existed on redtop seed since 1922 and were increased sufficiently in 1930 to provide an embargo against importation (Table 24). Duties on all hays have been such as to exclude competition in domestic markets.

Redtop seed has commanded relatively high prices when supply has been kept near the level of consumption but when supply has been burdensome, prices have sagged to levels that made production unprofitable. Speculators have served somewhat as balance wheels in years of large supply but were mostly inactive during the 1931 and 1932 marketing seasons. 
Table 24.-TARiff Duties Levied on Redtop Seed and HAY, UNITED STATES

\begin{tabular}{|c|c|c|}
\hline Tariff act of- & Duty on seed, per pound & $\begin{array}{c}\text { Duty on hay, } \\
\text { per ton }\end{array}$ \\
\hline 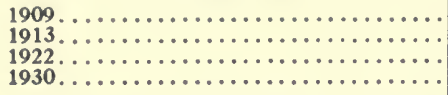 & $\begin{array}{l}\text { Free } \\
\text { Free } \\
2 \text { cents (under classification of n.s.p.f.b) } \\
40 \text { cents (bent grass seed, genus } A \text { grostis) }\end{array}$ & $\begin{array}{r}\$ 4 \\
2 \\
4 \\
5\end{array}$ \\
\hline
\end{tabular}

-No separation made as to kinds of hay. bn.s.p.f. = "not specially provided for."

\section{FARM MANAGEMENT ASPECTS OF REDTOP PRO- DUCTION IN SOUTHERN ILLINOIS}

The place which redtop fills in the organization of farms in the southern Illinois redtop district involves many considerations affecting the relative profitableness of the crop, its use in the cropping system, and the purposes for which it is grown. ${ }^{15 *}$ Tho the redtop district can

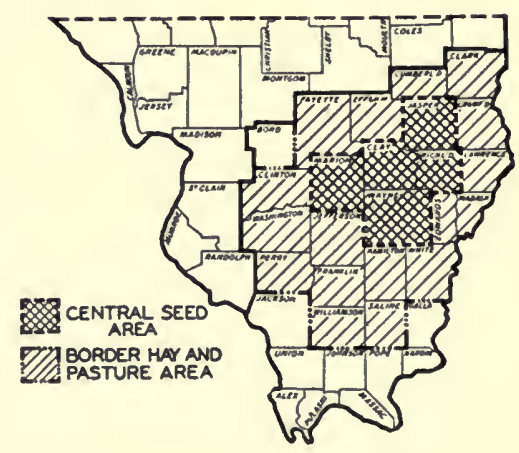

Fig. 22.-Illinois Redtop District as Separated into the Central or Seed Area, and the Border or Hay and Pasture Area

The counties in the central area include the heart of the redtop seed-producing territory of Illinois. Seed production has also been important in those parts of the border counties that are next to the redtop seed-producing area. The use of redtop for hay and pasture predominates in the outer area.

be divided into a central or seed-producing area and a border or hay and pasture area, as indicated in Fig. 22, the general organization and the financial returns from farms in the two areas are similar, according to an analysis made of farm records for the years 1928-1932." Redtopproducing farms in these areas differ chiefly in their cropping systems, particularly in the acreages and uses of the redtop crop.

'See footnote, page 277. 


\section{Relative Profitableness of Redtop}

While redtop is a crop of low gross income per acre, it has the advantage of low production costs. When relative costs of nine crops in southern Illinois, as determined for the ten-year period 1913$1922,{ }^{10 *}$ were adjusted to the scale of operating costs prevailing in 1931 and 1932, redtop showed the lowest acre-cost and the lowest labor and power requirements (Table 25 ).

Crops with a relatively low gross income, such as redtop, timothy, and mixed hay, may prove as profitable, because of their lower acrecosts, as crops with higher gross returns, altho they add less to the total volume of the farm business.

In producing hay and seed crops not only is a large share of the labor and power requirements limited to harvesting operations, but there is little conflict with the requirements of grain crops, and hence a larger total acreage can be handled without a proportionate increase in the demand for labor and power. This is particularly true in the redtop district where, because of soil conditions, the acreage of springplanted crops that can be handled is definitely limited. The total crop area of a farm can be enlarged if crops are grown that require no early spring work.

\section{Extent to Which Period of Study Was Normal}

Farm records for the years 1928-1932 form the basis for the following analysis of redtop production on farms in southern Illinois.

Table 25.-Costs per Acre of Producing Redtop and Eight Other Leading

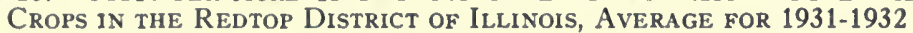

\begin{tabular}{|c|c|c|c|c|c|c|c|c|c|}
\hline Item & $\begin{array}{l}\text { Red- } \\
\text { top }\end{array}$ & Corn & Wheat & Oats & Clover & $\operatorname{timy}_{\text {thy }}^{\text {Timo }}$ & $\underset{\text { hay }}{\text { Mixed }}$ & $\begin{array}{l}\text { Cow- } \\
\text { peas }\end{array}$ & $\begin{array}{l}\text { Soy- } \\
\text { bean } \\
\text { hay }\end{array}$ \\
\hline 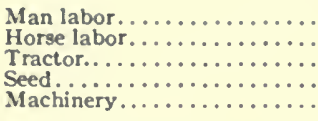 & $\begin{array}{r}.98 \\
.66 \\
.08 \\
.08 \\
.25\end{array}$ & $\begin{array}{r}\$ 3.18 \\
5.32 \\
.13 \\
.11 \\
.98\end{array}$ & $\begin{array}{r}\$ 2.90 \\
3.66 \\
.34 \\
.74 \\
.76\end{array}$ & $\begin{array}{r}\$ 1.83 \\
2.38 \\
.14 \\
.54 \\
.56\end{array}$ & $\begin{array}{r}\$ 1.54 \\
1.27 \\
\cdots .60 \\
.42\end{array}$ & $\begin{array}{r}\$ 1.11 \\
.88 \\
\because .15 \\
.30\end{array}$ & $\begin{array}{r}\$ 1.20 \\
.82 \\
\because .80 \\
.40 \\
.26\end{array}$ & $\begin{array}{r}\$ 2.50 \\
3.20 \\
\cdots \\
.75 \\
.76\end{array}$ & $\begin{array}{r}\$ 1.65 \\
2.26 \\
. .65 \\
.68\end{array}$ \\
\hline 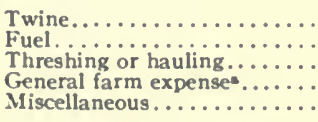 & $\begin{array}{l}\cdots \\
.33 \\
.76 \\
.08\end{array}$ & $\begin{array}{r}\cdots \\
3.46 \\
3.46\end{array}$ & $\begin{array}{r}.28 \\
.04 \\
.55 \\
2.31 \\
2.11\end{array}$ & $\begin{array}{l}.25 \\
.04 \\
.42 \\
1.61 \\
1.42\end{array}$ & $\begin{array}{l}\cdots \\
\cdots \\
i .32 \\
1.06\end{array}$ & $\begin{array}{l}\cdots \\
\cdots \\
\because 9 i \\
.26\end{array}$ & $\begin{array}{r}\because 15 \\
1.15 \\
.41\end{array}$ & $\begin{array}{r}\cdots \\
2.35 \\
2.35 \\
.57\end{array}$ & $\begin{array}{l}\cdots \cdots \\
\cdots \cdots \\
i .21 \\
1.17\end{array}$ \\
\hline $\begin{array}{l}\text { Total operating expense..... } \\
\text { Interest on land at } 5 \text { percent.. } \\
\text { Total cost. . . . . . . . . . }\end{array}$ & $\begin{array}{l}\$ 3.14 \\
1.85 \\
\$ 4.99\end{array}$ & $\begin{array}{r}\$ 14.60 \\
1.85 \\
\$ 16.45\end{array}$ & $\begin{array}{r}\$ 13.69 \\
1.85 \\
\$ 15.54\end{array}$ & $\begin{array}{r}\$ 9.19 \\
1.85 \\
\$ 11.04\end{array}$ & $\begin{array}{l}\$ 6.21 \\
1.85 \\
\$ 8.06\end{array}$ & $\begin{array}{l}\$ 3.61 \\
1.85 \\
\$ 5.46\end{array}$ & $\begin{array}{r}\$ 4.39 \\
1.85 \\
\$ 6.24\end{array}$ & $\begin{array}{r}\$ 10.36 \\
1.85 \\
\$ 12.21\end{array}$ & $\begin{array}{l}\$ 7.62 \\
1.85 \\
\$ 9.47\end{array}$ \\
\hline 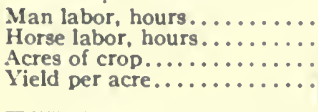 & $\begin{array}{l}6.5 \\
6.6 \\
197 \\
.54 \mathrm{~T}\end{array}$ & $\mid \begin{array}{c}25.9 \\
53.2 \\
1 \\
23.4 \text { bu. }\end{array}$ & $\mid \begin{array}{cc}19.3 \\
36.6 \\
1 & 675 \\
13.8 \mathrm{bu}\end{array}$ & $\left|\begin{array}{cc}12.2 \\
23.8 \\
1.058 \\
21.1 \text { bu. }\end{array}\right|$ & $\begin{array}{c}10.3 \\
12.7 \\
608 \\
1.37 \mathrm{~T}\end{array}$ & $\begin{array}{l}7.4 \\
8.8 \\
658 \\
.89 T\end{array}$ & $\begin{array}{l}8.0 \\
8.2 \\
221 \\
.94 \mathrm{~T}\end{array}$ & $\begin{array}{l}16.7 \\
32.0 \\
248 \\
.61 \mathrm{~T}\end{array}$ & $\begin{array}{l}11.0 \\
22.6 \\
24 \\
1.03 \mathrm{~T}\end{array}$ \\
\hline
\end{tabular}

- Taxes are included under general farm expense. 
The conditions which prevailed in the redtop district during this period were significant since extreme variations in rainfall affected markedly the volume of crop production and the decline in price-levels affected the returns for all farm products.

Rainfall.-Annual rainfall data from ten stations well distributed over the redtop district, five in the redtop seed-producing area and five in the hay and pasture area, show definite variations in amount of rainfall from year to year but relatively uniform precipitation from month to month thruout the entire district.

\section{Annual Rainfall in Illinois Redtop District}

\begin{tabular}{|c|c|c|}
\hline & $\begin{array}{c}\text { Five stations in } \\
\text { central or } \\
\text { seed area } \\
\text { inches }\end{array}$ & $\begin{array}{l}\text { Five stations in } \\
\text { border or hay and } \\
\text { pasture area } \\
\text { inches }\end{array}$ \\
\hline 1928. & 42.84 & 45.31 \\
\hline & 48.12 & 48.21 \\
\hline & 31.20 & 33.45 \\
\hline$\cdots$ & 43.59 & 42.91 \\
\hline & 41.89 & 46.19 \\
\hline year average. & 41.53 & 43.21 \\
\hline $\operatorname{rrmal} \ldots \ldots \ldots \ldots \ldots \ldots \ldots \ldots \ldots \ldots$ & 42.85 & 39.81 \\
\hline
\end{tabular}

Weather conditions for the crop year 1928 were quite favorable during the spring seeding period, but excessive rainfall in June made cultivation almost impossible, as a result of which feed crops were late and weedy and production restricted. In contrast, the crop season of 1929 started with a wet April and May, and difficulty was experienced in planting crops. Favorable weather later, however, resulted in a good corn crop and fairly good hay crops altho yields of small grains were reduced.

In 1930 the greatest variations in temperature and the most severe drouth on record were recorded in the redtop district. The drouth started in March, and during the six-month period of March thru August the rainfall at the ten stations in the district was from 27 to 53 percent of normal. This lack of sufficient rainfall, together with very hot weather in July and August, severely reduced the yields of nearly all crops in the redtop district.

The year 1931 was.generally above normal in temperature, with several periods of extreme heat during the summer. Rainfall was well distributed thruout the growing season, and crop yields were the best of any year during this period. During 1932 favorable temperatures prevailed during the crop season, and altho precipitation was less than normal during the period from February thru June, the crop yields were not generally curtailed. 
Because of soil conditions in the redtop district, extremes of temperature or rainfall exert noticeable effects upon crop production. Yet despite the wide variations in yields from year to year as a result of weather conditions, average yields obtained on the record-keeping farms in the two areas of the district during the five-year period 1928-1932 (Table 26) were representative of a much longer period. ${ }^{a}$

TABLE 26.-CROP YieldS ON Record-KeEPING FARMS IN THE Redtop DISTRICT OF IllLiNOIS, 1928-1932

\begin{tabular}{|c|c|c|c|c|c|c|}
\hline Item & 1928 & 1929 & 1930 & 1931 & 1932 & Average \\
\hline \multicolumn{7}{|c|}{ Central area } \\
\hline 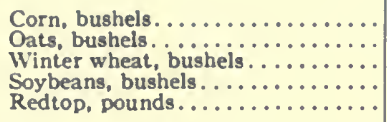 & $\begin{array}{r}20.0 \\
26.3 \\
5.9 \\
4.2 \\
45.0\end{array}$ & $\begin{array}{r}27.8 \\
15.8 \\
10.7 \\
7.7 \\
44.0\end{array}$ & $\begin{array}{r}13.8 \\
26.3 \\
15.9 \\
8.1 \\
38.0\end{array}$ & $\begin{array}{l}31.2 \\
30.6 \\
30.9 \\
13.0 \\
80.0\end{array}$ & $\begin{array}{r}32.3 \\
16.8 \\
9.7 \\
7.9 \\
99.0\end{array}$ & $\begin{array}{r}25.1 \\
23.2 \\
14.6 \\
8.2 \\
61.0\end{array}$ \\
\hline 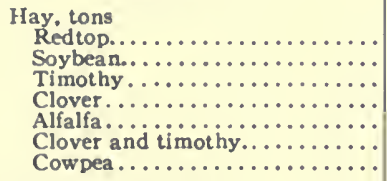 & $\begin{array}{r}\cdots \\
.85 \\
.55 \\
\ddot{2.00} \\
\cdots \cdots \\
\cdots \cdots\end{array}$ & $\begin{array}{r}.72 \\
.84 \\
.89 \\
1.19 \\
1.33 \\
.83 \\
\ldots .\end{array}$ & $\begin{array}{l}.36 \\
.76 \\
.90 \\
.80 \\
.20 \\
.60 \\
.80\end{array}$ & $\begin{array}{r}.58 \\
1.26 \\
1.35 \\
1.00 \\
1.00 \\
1.50\end{array}$ & $\begin{array}{r}.53 \\
1.13 \\
.91 \\
1.45 \\
\ldots .98 \\
1.89\end{array}$ & $\begin{array}{r}.55 \\
.97 \\
.88 \\
1.11 \\
1.18 \\
.83 \\
1.20\end{array}$ \\
\hline 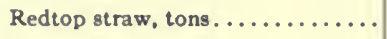 & .39 & .64 & .30 & .60 & .49 & .48 \\
\hline 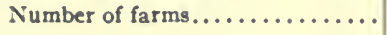 & 16 & 35 & 20 & 30 & 19 & 120 (Total) \\
\hline
\end{tabular}

Border area

\begin{tabular}{|c|c|c|c|c|c|c|}
\hline 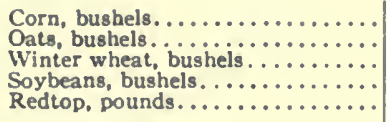 & $\begin{array}{r}18.5 \\
30.2 \\
3.4 \\
6.7 \\
63.0\end{array}$ & $\begin{array}{r}30.7 \\
19.1 \\
14.2 \\
9.5 \\
32.0\end{array}$ & $\begin{array}{r}12.2 \\
16.1 \\
12.4 \\
6.5 \\
33.0\end{array}$ & $\begin{array}{r}31.3 \\
34.3 \\
27.1 \\
9.3 \\
73.0\end{array}$ & $\begin{array}{l}30.8 \\
21.1 \\
13.6 \\
11.2 \\
74.0\end{array}$ & $\begin{array}{r}24.7 \\
24.2 \\
14.1 \\
8.6 \\
55.0\end{array}$ \\
\hline 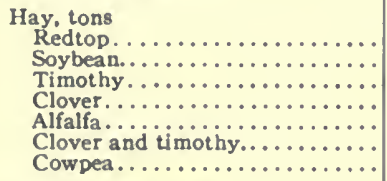 & $\begin{array}{r}.70 \\
1.09 \\
.95 \\
1.24 \\
1.50 \\
\cdots .97\end{array}$ & $\begin{array}{r}.81 \\
1.14 \\
1.08 \\
1.46 \\
1.61 \\
1.35 \\
\ldots . .\end{array}$ & $\begin{array}{l}.36 \\
.80 \\
.40 \\
.81 \\
.83 \\
.66 \\
.70\end{array}$ & $\begin{array}{r}.66 \\
1.38 \\
1.27 \\
1.21 \\
2.19 \\
.77 \\
1.12\end{array}$ & $\begin{array}{r}.59 \\
1.32 \\
.67 \\
1.06 \\
1.07 \\
1.008\end{array}$ & $\begin{array}{r}.61 \\
1.15 \\
.87 \\
1.16 \\
1.44 \\
.93 \\
.97\end{array}$ \\
\hline 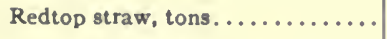 & .53 & .76 & .41 & .56 & .38 & .53 \\
\hline 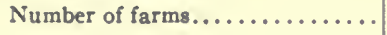 & 16 & 31 & 36 & 46 & 30 & 159 (Total) \\
\hline
\end{tabular}

Price Conditions.-During the period 1928-1932 farm earnings in the redtop district were affected by price changes more than by climatic conditions. For the first two years of the period prices of farm

-See Illinois Cooperative Crop Reporting Service statistics for 1921-1930. Averages of such statistics for counties were compiled by the Illinois Agricultural Experiment Station and issued in mimeograph form in July, 1932. 
products were relatively stable, but during the last three years prices of nearly all products of the district experienced a continuous and drastic decline. This situation affected farm incomes during those years, not only because of lower prices received for each succeeding

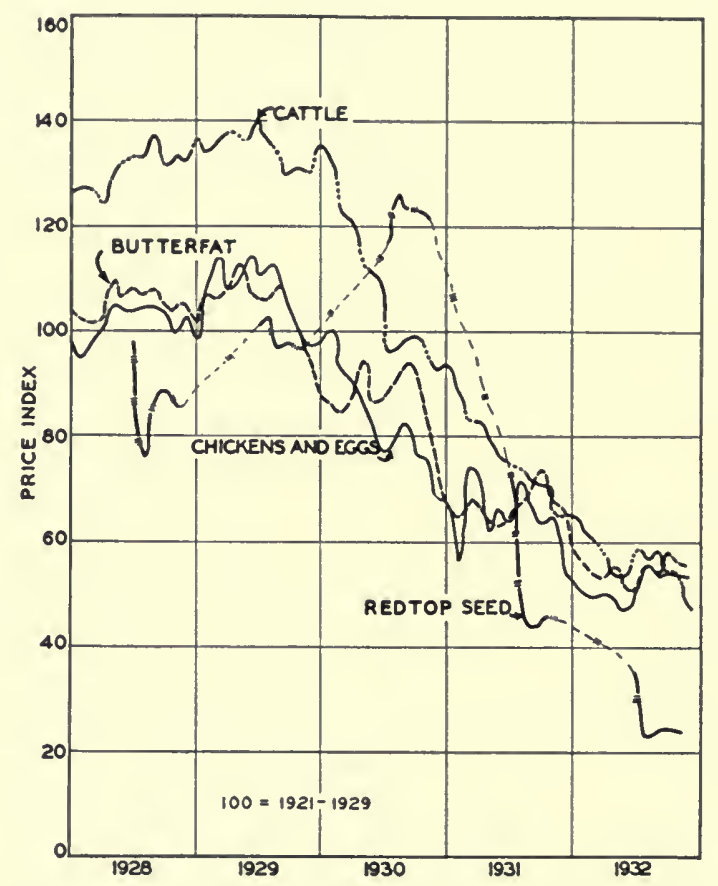

Fig. 23.-Monthly Farm Prices of Cattle, Dairy Products, Poultry and

Poultry Products, ANd Redtop Seed in Illinois in 1928-1932,

EXPRESSED in Terms of 1921-1929 Prices

In 1930, when relative prices of other products important in southern Illinois were evidencing continued and marked decline, the price of redtop seed advanced. Thereafter the price of redtop seed dropped until by August, 1932, it was less than 25 percent of the basic figure.

year's production, but also because of the necessity of writing down each year the value of inventories of livestock and feed on hand. Gross receipts from sale of farm products from farms keeping records in this district have been derived chiefly from livestock and livestock products, with lesser amounts from wheat and other grain and from redtop seed (Figs. 23 and 24 ).

Because of the emergency adjustments made necessary by the drastic price declines, the value of the records lies chiefly in the light 
they throw upon the organization of the redtop farms, which changes slowly, and in the use made of the redtop crop.

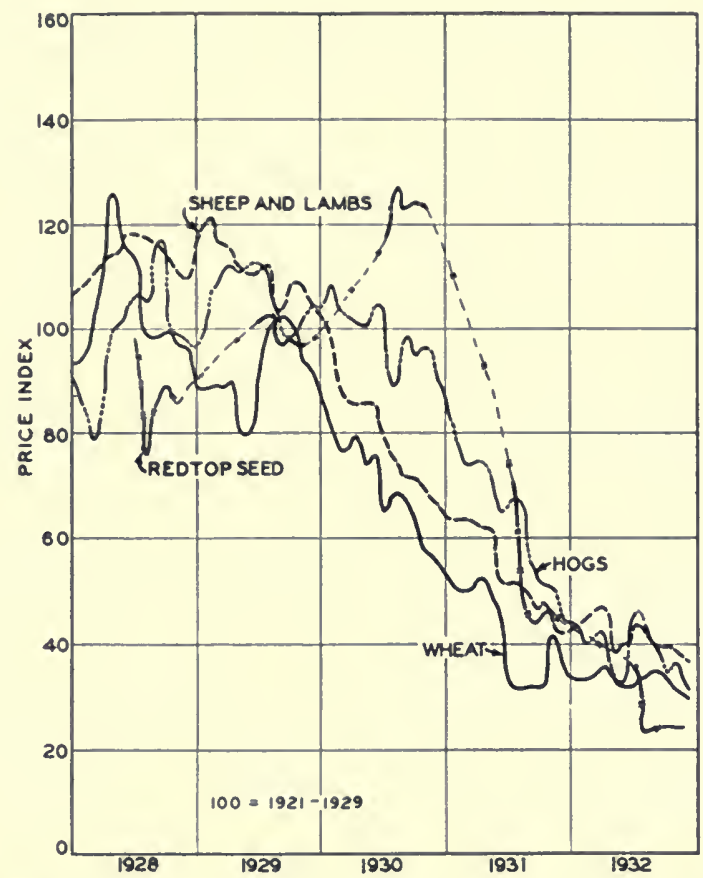

Fig. 24.-Monthly Farm Prices of Hogs, Sheep and Lambs, Wheat, and Redtop Seed in Illinois in 1928-1932, Expressed IN Terms of 1921-1929 Prices

None of the other farm products dropped to so low a relative point as redtop during this period, altho the price of wheat declined earlier and has been low for a longer period.

\section{Organization of Redtop Farms in the Redtop District}

The general features of the organization of farms in the central, or redtop seed, area and in the border, or redtop hay, area were found to be quite similar, according to data covering the period 1928-1932 (Table 27). ${ }^{\mathrm{a}}$

"This analysis of farm organization is based upon farm financial records kept by farmers in cooperation with their county farm bureaus and the University of Illinois for the five-year period 1928-1932. For this period a total of 120 records are available for farms growing redtop in the central or seed area, comprizing Wayne, Marion, Clay, Richland, and Jasper counties, and 159 records in the border or hay and pasture area consisting of 17 counties (Fig. 22). 
TABLE 27.-Crop ACreages AND INVEstments on ReCORd-KeEPING Farms in the REDTOP DISTRICT OF ILLINOIS, AVERAGE FOR 1928-1932

\begin{tabular}{|c|c|c|c|c|}
\hline \multirow[b]{2}{*}{ Total number of records.................... } & \multicolumn{2}{|c|}{$\begin{array}{l}\text { Central redtop } \\
\text { area. }\end{array}$} & \multicolumn{2}{|c|}{$\begin{array}{c}\text { Border redtop } \\
\text { area }\end{array}$} \\
\hline & 120 & & 159 & \\
\hline 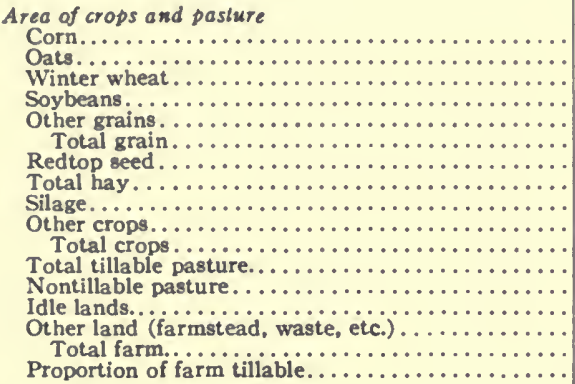 & $\begin{array}{c}\text { acres } \\
32.4 \\
18.3 \\
11.2 \\
3.2 \\
.6 \\
(65.7) \\
34.0 \\
26.5 \\
4.1 \\
3.7 \\
(134.1) \\
52.1 \\
11.4 \\
4.4 \\
14.9 \\
(216.9) \\
\ldots . .\end{array}$ & $\begin{array}{l}\text { perct. } \\
\ldots \\
\ldots \\
\ldots \\
\ldots \\
\ldots \\
\ldots \\
\ldots \\
\ldots \\
\ldots \\
\ldots \\
\ldots \\
\ldots \\
\ldots \\
\ldots \\
87 \\
\ldots 7\end{array}$ & $\begin{array}{c}a c r e s \\
32.8 \\
19.1 \\
20.7 \\
2.1 \\
.3 \\
(75.0) \\
12.3 \\
25.0 \\
2.6 \\
2.5 \\
(117.4) \\
45.8 \\
5.9 \\
2.1 \\
17.3 \\
(188.5) \\
\ldots \ldots\end{array}$ & $\begin{array}{l}\text { perct. } \\
\ldots \\
\ldots \\
\ldots \\
\ldots \\
\ldots \\
\ldots \\
\ldots \\
\ldots \\
\ldots \\
\ldots \\
\ldots \\
\ldots \\
\ldots \\
\ldots \\
\dot{8} \bar{*} \\
\ldots\end{array}$ \\
\hline 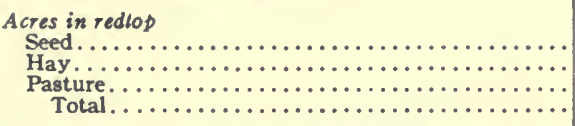 & $\begin{array}{r}34.0 \\
5.4 \\
15.2 \\
(54.6)\end{array}$ & $\begin{array}{l}62.0 \\
10.2 \\
27.8 \\
\cdots\end{array}$ & $\begin{array}{r}12.3 \\
7.0 \\
18.9 \\
(38.2)\end{array}$ & $\begin{array}{l}32.6 \\
18.3 \\
49.1 \\
\cdots\end{array}$ \\
\hline $\begin{array}{l}\text { Proportion of tillable area in redtop for all uses ...... } \\
\text { Proportion of hay acreage in redtop hay........... } \\
\text { Proportion of tillable pasture in redtop pasture..... } \\
\text { Proportion of crop sales from redtop seed and hay... } \\
\text { Proportion of all cash receipts from redtop seed and hay }\end{array}$ & $\begin{array}{l}\cdots \\
\cdots \\
\cdots \\
\cdots \\
\cdots\end{array}$ & $\begin{array}{r}28.9 \\
17.6 \\
30.0 \\
39.3 \\
7.7\end{array}$ & $\begin{array}{l}\cdots \\
\cdots \\
\cdots \\
\cdots \\
\cdots\end{array}$ & $\begin{array}{r}22.9 \\
27.4 \\
40.9 \\
17.1 \\
2.8\end{array}$ \\
\hline 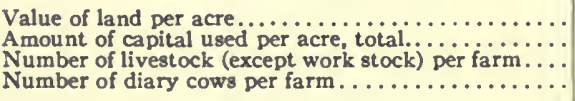 & $\begin{array}{r}\$ 33.86 \\
58.61 \\
6.01 \\
6.9\end{array}$ & $\begin{array}{l}\cdots \\
\cdots \\
\cdots\end{array}$ & $\begin{array}{r}\$ 39.80 \\
66.53 \\
5.91 \\
5.5\end{array}$ & $\begin{array}{l}\ldots \\
\ldots \\
\ldots\end{array}$ \\
\hline
\end{tabular}

Farms in the seed area averaged about 30 acres larger in size than the farms in the hay and pasture area, but the proportion of tillable land and the average acreages per farm of grain crops other than winter wheat and acreages of hay and tillable pasture were quite comparable. Less winter wheat was grown on farms in the seed area and nearly twice as much nontillable pasture was found on these farms as on the farms in the border area.

The two areas differed chiefly in acreage of redtop and in the proportion of direct cash returns from this crop. In neither area did redtop sales constitute a large proportion of the total cash receipts, altho they represented almost two-fifths of the crop sales in the central area.

The average acre-value of land and the average total investment in the farm business were similar in the two areas, as was also the investment per acre in livestock other than work stock. Of the livestock, cattle were the most important both in amount of investment 
and in sales of livestock and livestock products. Farms in the seed area averaged 6.9 cows per farm, compared with 5.5 in the border area. In both areas poultry and eggs were an important source of income. Larger numbers of hogs were found in the hay and pasture area than in the seed area, tho in both areas the numbers were small compared with the state average. Some sheep were kept in each area, tho the investment was larger in the seed area.

The reporting farms in the central and border redtop areas were but little influenced by the specialized fruit production or by dairy farming, tho both industries have assumed important proportions in some sections of the areas.

\section{Redtop in the Cropping System}

The differences in the cropping systems of the central or redtop seed area and the border or redtop hay area have been greatest in regard to the redtop crop. Returns from redtop in the seed area were largely direct from the sales of seed and hay, but in the hay and pasture area, the returns were largely indirect, the result of the use of redtop in the production of livestock and livestock products. The following summary shows the acreages devoted to seed, hay, and pasture in each area in 1928-1932 and the percentage which each acreage was of the total redtop acreage of the area.

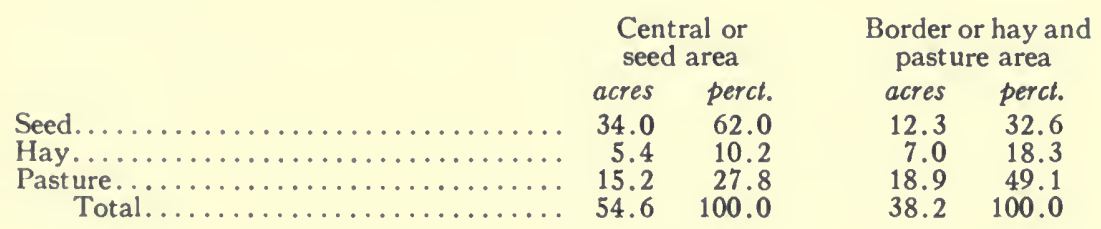

The small proportion of farm receipts from crops in the central or seed area and the large part from livestock and livestock products indicates that the major part of the crops grown has been utilized on the farm. The proportion of the farm acreage used for various kinds of crops on record-keeping farms in the redtop district is shown in Table 28.

Classes of Crops.-Grain and seed crops made up slightly less than half the farm acreage in the central or seed area, redtop seed accounting for about one-third of this amount on the record-keeping farms in 1928-1932. The hay, silage, and grazing area occupied nearly as much of the land as the grain and seed crops. About one-sixth of the pasture area was untillable. The kinds of feed and cash crops raised 
Table 28.-Proportions of Farm Acreage Used for Various Kinds of Crops on Record-Keeping Farms, Central or Seed Area, Redtop District OF ILLINOIS, 1928-1932

\begin{tabular}{c|c|c|c|c|c|c}
\hline Item & 1928 & 1929 & 1930 & 1931 & 1932 & Average \\
\hline $\begin{array}{c}\text { Number of records......... } \\
\text { Average gize of farm, acres... }\end{array}$ & 216.9 & 200.6 & 232.0 & 215.5 & 224.4 & 216.9 \\
\hline
\end{tabular}

Percentage of farm area used as specified

\begin{tabular}{|c|c|c|c|c|c|c|}
\hline 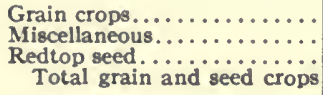 & $\begin{array}{r}22.4 \\
3.5 \\
20.3 \\
46.2\end{array}$ & $\begin{array}{r}29.3 \\
1.3 \\
18.9 \\
49.5\end{array}$ & $\begin{array}{r}32.9 \\
1.7 \\
12.3 \\
46.9\end{array}$ & $\begin{array}{r}34.8 \\
1.9 \\
15.6 \\
52.3\end{array}$ & $\begin{array}{r}31.7 \\
11.7 \\
44.9\end{array}$ & $\begin{array}{r}30.3 \\
1.7 \\
15.7 \\
47.7\end{array}$ \\
\hline 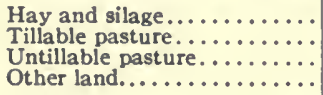 & $\begin{array}{r}15.1 \\
27.8 \\
2.5 \\
8.4\end{array}$ & $\begin{array}{r}11.5 \\
21.9 \\
4.6 \\
12.5\end{array}$ & $\begin{array}{r}15.9 \\
23.6 \\
5.0 \\
8.6\end{array}$ & $\begin{array}{r}10.7 \\
22.4 \\
5.1 \\
9.5\end{array}$ & $\begin{array}{r}17.0 \\
24.3 \\
8.7 \\
5.7\end{array}$ & $\begin{array}{r}14.1 \\
24.0 \\
5.3 \\
8.9\end{array}$ \\
\hline 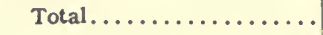 & 100.0 & 100.0 & 100.0 & 100.0 & 100.0 & 100.0 \\
\hline
\end{tabular}

and the place which redtop occupied on these farms are shown in Table 29.

With the smaller area per farm in the border or hay and pasture area, a larger proportion of the land was in grain crops but less in redtop seed and hay in 1928-1932 than in the seed area. Redtop was more important as a pasture crop than as a seed or hay crop (Table $30)$.

Hay Crops.-A large variety of harvested forage crops was used on the reporting farms in both areas, but there were but few individual farms that used more than two kinds of such feed (Table 31).

Soybeans were the most generally grown hay crop, followed by redtop and timothy. The acid character of the soil has definitely limited the acreages of clovers and alfalfa where liming programs have not been undertaken. From a feed standpoint it is significant that 69 percent of the hay acreage in the central area and 57 percent in the border area during the five-year period 1928-1932 were devoted to legumes, and that the yields of legume hays were higher than those of nonlegumes (Table 26). One-fifth of the record-keeping farms in both groups used silage in addition to hay crops.

Pasture Crops.-Pasture crops, like hay crops, present a variety for the central or seed area as a whole. On individual farms, however, there has been a tendency for the number of such crops to be limited. About one-third of the record-keeping farms in the two areas had some nontillable pasture. Of the pasture crops on tillable land redtop and bluegrass were grown most widely (Table 32). In about one-fifth of the fields of redtop, this grass was mixed with 
Table 29.-Average Acreage per Farm in Specified Crops, in Tillable PasTURES, ANd in Miscellaneous Uses, oN RECord-KeEPING FarMs, Central or SeEd ARea, Redtop District of Illinois, 1928-1932

\begin{tabular}{|c|c|c|c|c|c|c|}
\hline Item & 1928 & 1929 & 1930 & 1931 & 1932 & Average \\
\hline $\begin{array}{l}\text { Number of records.......... } \\
\text { Average size of farm, acres... }\end{array}$ & $\begin{array}{l}16 \\
211.9\end{array}$ & $\begin{array}{c}35 \\
200.6\end{array}$ & $\begin{array}{l}20 \\
232.0\end{array}$ & $\begin{array}{l}30 \\
215.6\end{array}$ & $\begin{array}{c}19 \\
224.4\end{array}$ & $\begin{array}{c}24 \\
216.9\end{array}$ \\
\hline 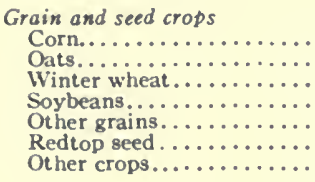 & $\begin{array}{r}\text { acres } \\
23.6 \\
17.1 \\
4.9 \\
1.4 \\
.4 \\
43.0 \\
7.3\end{array}$ & $\begin{array}{r}\text { acres } \\
34.3 \\
11.6 \\
8.5 \\
3.7 \\
37.7 \\
2.7\end{array}$ & $\begin{array}{r}\text { acres } \\
32.3 \\
22.6 \\
16.4 \\
4.8 \\
. .2 \\
28.6 \\
3.8\end{array}$ & $\begin{array}{r}\text { acres } \\
36.2 \\
18.9 \\
13.8 \\
4.2 \\
1.8 \\
33.7 \\
4.2\end{array}$ & $\begin{array}{r}\text { acres } \\
35.4 \\
21.3 \\
12.7 \\
1.7 \\
26.7 \\
1.5\end{array}$ & $\begin{array}{r}\text { acres } \\
32.4 \\
18.3 \\
11.2 \\
3.2 \\
.6 \\
34.0 \\
3.7\end{array}$ \\
\hline Total........... & 97.7 & 99.4 & 108.7 & 112.8 & 99.3 & $\overline{103.4}$ \\
\hline \multicolumn{7}{|l|}{$\begin{array}{l}\text { Hay and silage crops } \\
\text { Nonlegume }\end{array}$} \\
\hline $\begin{array}{l}\text { Redtop........... } \\
\text { Timothy....... }\end{array}$ & 2.9 & 4.5 & 4.5 & 3.7 & 11.3 & 5.4 \\
\hline 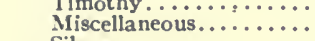 & & .4 & & .2 & 1.4 & $\begin{array}{r}.0 \\
.4\end{array}$ \\
\hline 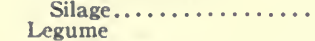 & 2.8 & 1.9 & 10.7 & 1.9 & 3.1 & 4.1 \\
\hline Soybeans................ & 17.8 & 10.2 & 12.7 & 15.2 & 14.6 & 14.1 \\
\hline Cowpeas........... & $\cdots$ & 1.5 & .26 & .3 & 2.5 & .06 \\
\hline Clover and timothy.... & … & 1.2 & 1.9 & .3 & .8 & .8 \\
\hline Alfalfa................ & .2 & .7 & 2.3 & ... & .... & .7 \\
\hline Total............... & 32.0 & 23.1 & 36.8 & 23.0 & 38.1 & 30.6 \\
\hline Tolal crops.................. & 129.7 & 122.4 & 145.5 & 135.8 & 137.4 & 134.1 \\
\hline \multicolumn{7}{|l|}{$\begin{array}{l}\text { Tillable pasture } \\
\text { Nonlegume }\end{array}$} \\
\hline Redtop......... & 8.9 & 16.7 & 12.1 & 6.4 & 13.5 & 11.5 \\
\hline Redtop, mixed. & 7.4 & 3.2 & 2.4 & 5.7 & 200 & 3.7 \\
\hline $\begin{array}{l}\text { Bluegrass......... } \\
\text { Timothy...... }\end{array}$ & 10.9 & $\begin{array}{r}11.1 \\
.3\end{array}$ & $\begin{array}{r}27.4 \\
2.0\end{array}$ & $\begin{array}{r}25.3 \\
.7\end{array}$ & $\begin{array}{r}29.0 \\
2.0\end{array}$ & $\begin{array}{r}20.7 \\
1.0\end{array}$ \\
\hline Mixed ............... & 18.8 & 5.8 & 1.4 & 1.2 & & 5.4 \\
\hline \multirow{2}{*}{\multicolumn{7}{|c|}{$\begin{array}{l}\text { Legume } \\
\text { Clover......... }\end{array}$}} \\
\hline & & & & & & \\
\hline Clover and timotiy...... & $\cdots$ & $\cdots$ & 6.9 & ?. & $\ddot{4} \ddot{4}$ & $2 . \dot{4}$ \\
\hline Sweet clover............ & 5.6 & 4.5 & 2.6 & 8.1 & 2.6 & 4.7 \\
\hline Total tillable pasture. & 590 & 43.9 & 54.8 & 48,2 & 546 & 52,1 \\
\hline $\begin{array}{l}\text { Nontillable pasture..... } \\
\text { Idle land.............. }\end{array}$ & $\begin{array}{l}5.3 \\
2.6\end{array}$ & $\begin{array}{l}9.3 \\
8.0\end{array}$ & $\begin{array}{r}11.5 \\
3.8\end{array}$ & $\begin{array}{r}11.0 \\
5.8\end{array}$ & $\begin{array}{r}19.6 \\
1.9\end{array}$ & $\begin{array}{r}11.4 \\
4.4\end{array}$ \\
\hline Other land.. & 15.3 & 17.0 & 16.4 & 14.7 & 10.9 & 14.9 \\
\hline
\end{tabular}

other pasture crops. Of the legume pasture crops, sweet clover was most important, occurring on about one-third of the farms in the seed area and on one-fourth in the hay area.

\section{Competition of Redtop With Other Crops}

The problem with respect to redtop in the counties in question has been not so much one of competition with other crops for the use of land and labor, as lack of such competition, and a consequent tendency to swell production of redtop beyond normal demands.

Conditions of soil and climate combine in these counties to set rather close limits to the acreages of annual spring-seeded crops that 
Table 30.-Average Acreage per Farm in Specified Crops, in Tillable Pastures, and in Miscellaneous Uses, on Record-Keeping Farms, Border or Hay and Pasture Area, Redtop District of Illinois, 1928-1932

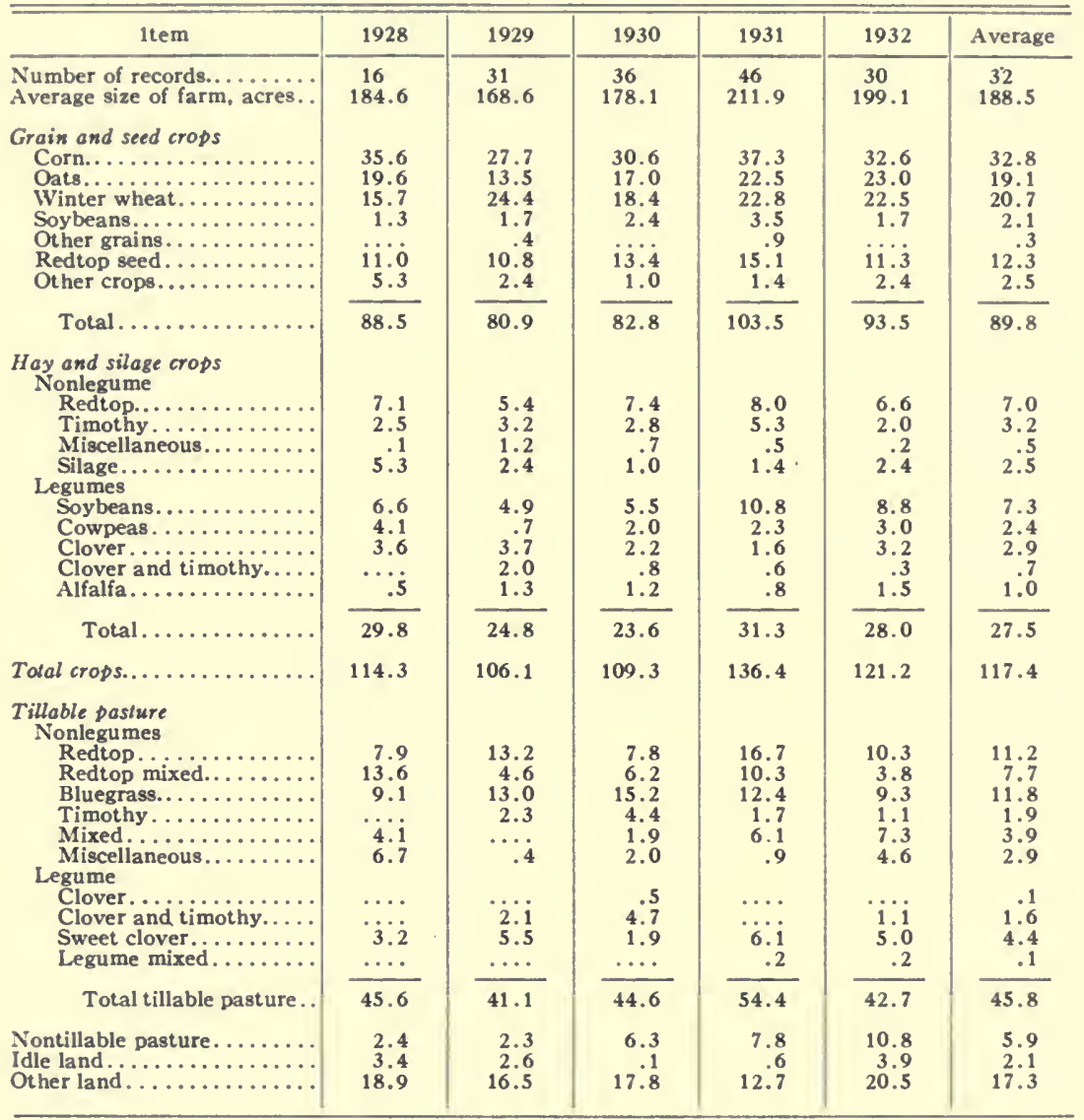

can be handled with the labor and equipment on the average farm. Therefore a crop such as redtop, which is not seeded in the spring or which stands for several years, supplements rather than competes with corn, wheat, oats, and annual hay crops, since it serves to increase the crop area. Redtop competes more directly with timothy (mixed with clover and unmixed), soybeans, cowpeas, and the clovers. The bulk of the redtop is sown on unlimed ground where clovers will not grow.

Timothy and clover require the same amount of labor at nearly the same time as redtop. The outcome of the competition between 
Table 31.-Proportion of Record-Keeping Farus Harvesting Specified Hay Crops and Silage, and Acreages of Each, Redtop

District OF ILLINOIS, 1928-1932

\begin{tabular}{|c|c|c|c|c|}
\hline \multirow[b]{2}{*}{ Item } & \multicolumn{2}{|c|}{ Central or seed area" } & \multicolumn{2}{|c|}{ Border or hay and pasture areab } \\
\hline & $\begin{array}{l}\text { Percentage } \\
\text { of farms } \\
\text { harvesting } \\
\text { crop }\end{array}$ & $\begin{array}{l}\text { Average } \\
\text { acreage } \\
\text { of crop } \\
\text { per farm }\end{array}$ & $\begin{array}{l}\text { Percentage } \\
\text { of farms } \\
\text { with crop } \\
\text { specified }\end{array}$ & $\begin{array}{l}\text { Average } \\
\text { acreage } \\
\text { of crop } \\
\text { per farm }\end{array}$ \\
\hline 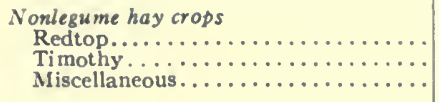 & $\begin{array}{l}26 \\
22 \\
\cdots\end{array}$ & $\begin{array}{l}20.0 \\
12.3 \\
\ldots \ldots\end{array}$ & $\begin{array}{r}34 \\
38 \\
9\end{array}$ & $\begin{array}{r}20.6 \\
12.4 \\
6.6\end{array}$ \\
\hline 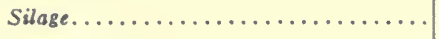 & 22 & 14.2 & 20 & 12.7 \\
\hline 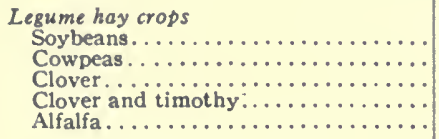 & $\begin{array}{r}81 \\
5 \\
12 \\
6 \\
5\end{array}$ & $\begin{array}{l}16.8 \\
14.4 \\
11.2 \\
13.4 \\
12.3\end{array}$ & $\begin{array}{r}59 \\
23 \\
21 \\
9 \\
16\end{array}$ & $\begin{array}{r}12.9 \\
10.2 \\
12.4 \\
9.1 \\
7.4\end{array}$ \\
\hline
\end{tabular}

-Based on records of farms for various portions of the period indicated, totaling 120 farm-years. based on records of farms for various portions of the period indicated, totaling 159 farm-years.

redtop and timothy is dependent mainly on their relative suitability to the locality, the utilization to be made of them, and the preference of individual producers.

Soybeans and cowpeas do not compete so directly with redtop from the labor standpoint inasmuch as their planting comes ahead of redtop harvest and their harvest time much later. In utilization on the farm, however, they displace much redtop hay or straw. Replies by farmers to an inquiry in 1932 as to what would be done with the

TABle 32.-Proportion of Record-KeEping Farms Having Various Kinds of Pasture Crops, and ACreages of Each, Redtop District of ILLINOIS, 1928-1932

\begin{tabular}{|c|c|c|c|c|}
\hline \multirow[b]{2}{*}{ Item } & \multicolumn{2}{|c|}{ Central or seed area" } & \multicolumn{2}{|c|}{ Border or hay and pasture areab } \\
\hline & $\begin{array}{l}\text { Percentage of } \\
\text { farms with } \\
\text { kind of pastur- } \\
\text { age indicated }\end{array}$ & $\begin{array}{l}\text { Average } \\
\text { acreage } \\
\text { in pasture } \\
\text { per farm }\end{array}$ & $\begin{array}{l}\text { Percentage } \\
\text { of farms } \\
\text { with crop } \\
\text { specified }\end{array}$ & $\begin{array}{l}\text { Average } \\
\text { acreage } \\
\text { of crop } \\
\text { per farm }\end{array}$ \\
\hline 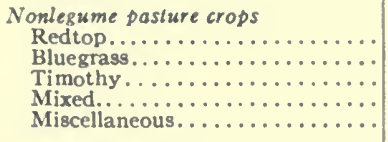 & $\begin{array}{r}43 \\
40 \\
6 \\
12 \\
\cdots\end{array}$ & $\begin{array}{l}35.9 \\
50.4 \\
15.6 \\
40.4 \\
\cdots\end{array}$ & $\begin{array}{r}57 \\
36 \\
8 \\
8 \\
10\end{array}$ & $\begin{array}{l}37.5 \\
37.3 \\
25.9 \\
28.2 \\
33.0\end{array}$ \\
\hline 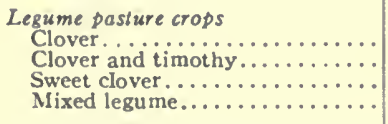 & $\begin{array}{l}\ddot{6} \\
32 \\
\cdots\end{array}$ & $\begin{array}{l}33.0 \\
15.2 \\
\cdots\end{array}$ & $\begin{array}{r}1 \\
6 \\
25 \\
3\end{array}$ & $\begin{array}{r}17.0 \\
23.2 \\
17.8 \\
9.4\end{array}$ \\
\hline
\end{tabular}

-See footnote a, Table 31. bSee footnote b, Table 31. 
released land if redtop seed acreage were cut 20 percent indicate that the land would be pastured or sown to legumes. On most farms the pasture would simply be redtop pasture.

Because of the sourness of most redtop land, the chief legumes planted in substitution for redtop would necessarily be soybeans and cowpeas. Increased production of legumes points toward increased ability to carry livestock successfully thru the winter, this in turn calling for more pasture in summer and a change in the manner of utilizing redtop rather than much decrease in acreage.

\section{Business Analysis of Account-Keeping Farms in the Redtop District}

A marked similarity existed not only in general organization but also in amounts and sources of receipts and in operating expenses on the record-keeping farms in the two areas of the redtop district. Data from the central or seed area will be used to illustrate the financial aspects of the farm business of the entire district.

Investments, Income, and Expenses. - The average acreage and the average valuation of real estate per farm on the record-keeping farms in the central or seed area during the period 1928-1932 were larger

Table 33.-Distribution of Farm Investments on Record-Keeping Faris, Central or Seed Area, Redtop District of Illinois, 1928-1932

\begin{tabular}{|c|c|c|c|c|c|c|}
\hline Item & 1928 & 1929 & 1930 & 1931 & 1932 & Average \\
\hline $\begin{array}{l}\text { Number of records.......... } \\
\text { Average size of farm, acres... }\end{array}$ & $\begin{array}{c}16 \\
211.9\end{array}$ & 200.6 & $\begin{array}{c}20 \\
232.0\end{array}$ & $\begin{array}{l}30 \\
215.5\end{array}$ & $\begin{array}{c}19 \\
224.4\end{array}$ & 216.9 \\
\hline 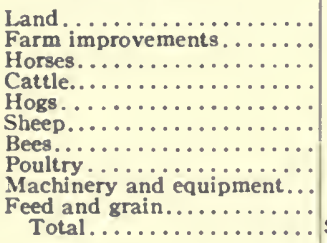 & \begin{tabular}{|rr}
$\$ 8$ & 310 \\
1 & 364 \\
283 \\
634 \\
\\
126 \\
258 \\
$7 \% 5$ \\
185 \\
765 \\
\\
$\quad 724$ \\
$\$ 12$ & 649
\end{tabular} & $\begin{array}{rr}\$ 6 & 938 \\
1 & 933 \\
364 \\
\\
& 731 \\
& 115 \\
& 141 \\
& 6 \\
& 202 \\
& 2045 \\
1 & 045 \\
& 816 \\
\$ 12 & 291\end{array}$ & $\begin{array}{rr}\$ 8 & 308 \\
2 & 509 \\
371 \\
1 & 125 \\
182 \\
\\
& 246 \\
& 7 \\
& 229 \\
1 & 269 \\
1 & 350 \\
\$ 15 & 596\end{array}$ & \begin{tabular}{|rr}
$\$ 6$ & 868 \\
1 & 815 \\
& 240 \\
& 754 \\
& 107 \\
& 119 \\
& 3 \\
& 190 \\
1 & 048 \\
& 803 \\
$\$ 11$ & 947
\end{tabular} & $\begin{array}{rr}\$ 6 & 301 \\
1 & 704 \\
277 \\
853 \\
94 \\
\\
54 \\
777 \\
171 \\
807 \\
821 \\
\$ 11 & 082\end{array}$ & $\begin{array}{rr}\$ 7 & 345 \\
1 & 863 \\
307 \\
820 \\
125 \\
164 \\
\\
3 \\
\\
196 \\
987 \\
903 \\
\$ 12 & 713\end{array}$ \\
\hline
\end{tabular}

than for all farms in these counties, as shown by the Census. ${ }^{12 *}$ Total valuations were low, however, when compared with many areas in the state, owing to a limited capacity for the production of farm products, at least for market disposal, and in turn to a relatively small volume of business per farm (Table 33).

Records of investment in different kinds of livestock on these farms show that, while only limited numbers of animals were being 
kept, returns from livestock and livestock products during the period 1928-1932 made up from 71.5 to 96.9 percent of the total farm receipts (Table 34 ). The returns from each item represent the net

Table 34.-Sources of Returss on Record-Keeping Farms, Central or Seed AREA, ReDtop District of Illino1s, 1928-1932

\begin{tabular}{|c|c|c|c|c|c|c|}
\hline Source of receipts & 1928 & 1929 & 1930 & 1931 & 1932 & Average \\
\hline \multicolumn{7}{|c|}{ Actual returns in dollars } \\
\hline 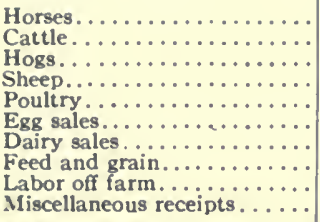 & $\begin{array}{r}11 \\
324 \\
165 \\
195 \\
104 \\
225 \\
585 \\
267 \\
79 \\
3\end{array}$ & $\begin{array}{r}\$ 31 \\
312 \\
88 \\
169 \\
341 \\
317 \\
477 \\
69 \\
3\end{array}$ & \begin{tabular}{r}
$\$ 258$ \\
400 \\
28 \\
157 \\
305 \\
487 \\
\hdashline 8 \\
4
\end{tabular} & $\begin{array}{r}\$ 34 \\
157 \\
17 \\
93 \\
222 \\
286 \\
301 \\
56 \\
5\end{array}$ & $\begin{array}{r}27 \\
73 \\
164 \\
16 \\
90 \\
184 \\
398 \\
\cdots \\
39 \\
1\end{array}$ & $\begin{array}{r}\$ 1 \\
222 \\
240 \\
69 \\
123 \\
255 \\
415 \\
145 \\
58 \\
3\end{array}$ \\
\hline Total receipts............ & $\$ 1958$ & $\$ 2097$ & $\$ 1678$ & \$1 271 & $\$ 992$ & $\$ 1531$ \\
\hline
\end{tabular}

Distribution of returns expressed as percentages of total returns

\begin{tabular}{|c|c|c|c|c|c|c|}
\hline 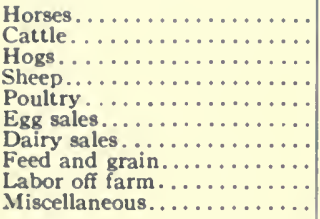 & $\begin{array}{r}.6 \\
16.6 \\
8.4 \\
10.0 \\
5.3 \\
11.5 \\
29.9 \\
13.6 \\
4.0 \\
.1\end{array}$ & $\begin{array}{r}15.3 \\
14.9 \\
4.2 \\
8.1 \\
16.3 \\
15.1 \\
22.7 \\
3.3 \\
.1\end{array}$ & $\begin{array}{r}15.3 \\
23.7 \\
1.7 \\
9.3 \\
18.1 \\
28.9 \\
2.8 \\
2.8 \\
.2\end{array}$ & $\begin{array}{r}10.5 \\
12.4 \\
1.3 \\
7.3 \\
17.5 \\
22.5 \\
23.7 \\
4.4 \\
.4\end{array}$ & $\begin{array}{r}2.7 \\
7.4 \\
16.5 \\
1.6 \\
9.1 \\
18.6 \\
40.1 \\
3.9 \\
.1\end{array}$ & $\begin{array}{r}14.1 \\
15.7 \\
4.5 \\
8.0 \\
16.6 \\
27.1 \\
9.5 \\
3.8 \\
.2\end{array}$ \\
\hline 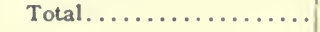 & 100.0 & 100.0 & 100.0 & 100.0 & 100.0 & 100.0 \\
\hline
\end{tabular}

gain after purchases, sales, and changes in inventory values are taken into account. The downward trend in total returns from these farms after 1929 is to be accounted for by the decline in prices of the products and not by a decrease in the physical quantities sold.

Yearly net gains recorded in the feed and grain account over the five-year period averaged only $\$ 145$ a farm, or an amount just equal to the sales of redtop seed from these farms. Crop sales included a considerable part of the wheat and some feed crops as well as redtop seed and hay. Sales of wheat and feed crops therefore offset the value of feeds purchased. On most farms crops were grown largely to meet the farm's feed requirements altho some emphasis was placed on producing readily salable crops.

In comparison with the central redtop area, the farm investment in the border or hay and pasture area showed somewhat more hogs and poultry and fewer cattle and sheep. On the farms in the border 
area livestock and livestock products accounted for an even greater proportion of the income, chiefly because of smaller sales of redtop seed.

The total volume of business on the farms in both areas, as measured by the gross returns, was small even in favorable years. No allowance has been made for farm-grown produce consumed by the farm family. Operating expenses include cash outlays for taxes, hired labor, repairs, and miscellaneous items and also depreciation on farm buildings, machinery and livestock, net losses on other accounts, and allowances for the labor of the operator and members of his family.

When total expenses (Table 35) are compared with gross reurns, the net income per farm left to apply on the invested capital and to

Table 35.-Distribution of Farm Expenses and Allowances, and Rate Earned on Record-Keeping Farms, Central or Seed Area, Redtop DisTRICT OF IlLINOIS, 1928-1932

\begin{tabular}{|c|c|c|c|c|c|c|}
\hline Item & 1928 & 1929 & 1930 & 1931 & 1932 & Average \\
\hline 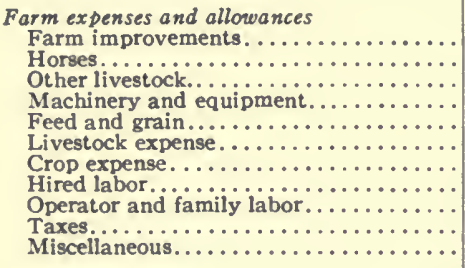 & $\begin{array}{r}\$ 85 \\
\ldots 2 \\
235 \\
\ldots \mathrm{ii} \\
159 \\
57 \\
831 \\
143 \\
22\end{array}$ & $\begin{array}{r}\$ 107 \\
4 \\
1 \\
156 \\
\cdots \ldots 7 \\
102 \\
121 \\
807 \\
136 \\
20\end{array}$ & $\begin{array}{r}\$ 140 \\
12 \\
25 \\
262 \\
56 \\
25 \\
151 \\
114 \\
807 \\
172 \\
27\end{array}$ & $\begin{array}{r}\$ 123 \\
14 \\
12 \\
121 \\
\cdots 10 \\
111 \\
103 \\
697 \\
122 \\
21\end{array}$ & $\begin{array}{r}\$ 116 \\
\cdots 5 i \\
187 \\
167 \\
20 \\
60 \\
62 \\
588 \\
120 \\
18\end{array}$ & $\begin{array}{r}\$ 114 \\
\cdots 18 \\
192 \\
\cdots 15 \\
117 \\
91 \\
746 \\
139 \\
22\end{array}$ \\
\hline Total expenses........ & $\$ 1545$ & $\$ 1461$ & $\$ 1791$ & $\$ 1334$ & $\$ 1389$ & $\$ 1454$ \\
\hline Net return............. & $\$ 313$ & $\$ 636$ & $\$-104$ & $s-63$ & $\$-397$ & $\$ 77$ \\
\hline 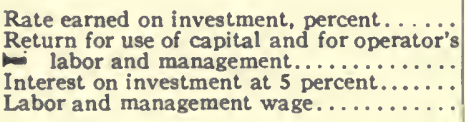 & $\begin{array}{r}2.5 \\
\$ 900 \\
632 \\
268\end{array}$ & $\begin{array}{rr}5 \\
\$ 1234 \\
614 \\
620\end{array}$ & $\begin{array}{r}-.7 \\
\$ 488 \\
780 \\
-282\end{array}$ & $\begin{array}{r}-.5 \\
\$ 404 \\
597 \\
-193\end{array}$ & 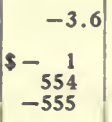 & $\begin{array}{r}\$ 605 \\
635 \\
-\quad 30\end{array}$ \\
\hline
\end{tabular}

pay for the managing ability of the operator amounted in the central or seed area to $\$ 313$ in 1928 and $\$ 636$ in 1929 , or 2.47 percent and 5.18 percent respectively of the total invested capital. In 1930, 1931, and 1932, however, because of the combined effects of the drouth in 1930 and of the price declines in all three years, the total yearly receipts lacked $\$ 104, \$ 63$, and $\$ 397$ respectively of equaling the total expenses. Since the labor and managing activities of the operator represent his time and effort and do not require a cash outlay, the return to the operator may be expressed as the balance remaining after the other operating expenses have been deducted from the gross re- 
turns and an allowance made for. the use of invested capital. Expressed in this way an average wage of $\$ 268$ was received by these farm operators in 1928 and of $\$ 620$ in 1929, in addition to the value of the contributions toward family living obtained directly from the farm, but in the three following years the total returns lacked $\$ 282$, $\$ 192$, and $\$ 555$ respectively of paying other expenses and compensating for the use of capital.

Expenses were practically the same in both areas, but because of lower receipts the farm operators in the hay area received approximately $\$ 100$ less per farm each year than those in the seed area.

Changes in Cash Receipts and Cash Expenses Since 1930.-Drastic price declines, such as those from 1930 to 1932, were naturally associated with adjustments in cash receipts and expenses. Noncash expenses, such as depreciation on farm buildings and machinery, increased because replacements and repairs were postponed, and reduc-

Table 36.-Distribution of Cash Receipts and Cash Expenses on RecordKeeping Farms, Central or Seed Area, Redtop District of ILLINOIS, 1928-1932

\begin{tabular}{|c|c|c|c|c|c|c|}
\hline Item & 1928 & 1929 & 1930 & 1931 & 1932 & Average \\
\hline 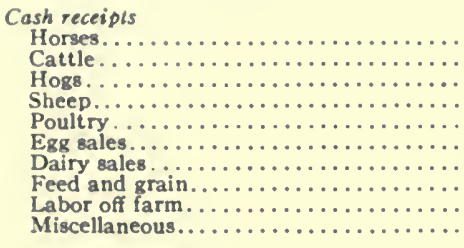 & $\begin{array}{r}18 \\
454 \\
230 \\
168 \\
131 \\
225 \\
585 \\
406 \\
79 \\
42\end{array}$ & $\begin{array}{r}\$ 47 \\
307 \\
317 \\
88 \\
179 \\
341 \\
317 \\
464 \\
69 \\
132\end{array}$ & $\begin{array}{r}\$ 43 \\
351 \\
454 \\
96 \\
172 \\
305 \\
487 \\
514 \\
48 \\
31 \\
\end{array}$ & $\begin{array}{r}\$ 16 \\
146 \\
203 \\
51 \\
118 \\
222 \\
286 \\
385 \\
56 \\
137\end{array}$ & $\begin{array}{r}544 \\
217 \\
193 \\
31 \\
111 \\
184 \\
398 \\
191 \\
39 \\
32\end{array}$ & $\begin{array}{r}34 \\
295 \\
279 \\
87 \\
142 \\
255 \\
415 \\
392 \\
58 \\
75\end{array}$ \\
\hline 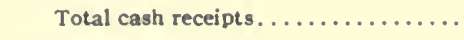 & $\$ 2338$ & $\$ 2261$ & $\$ 2501$ & $\$ 1620$ & $\$ 1440$ & $\$ 2032$ \\
\hline 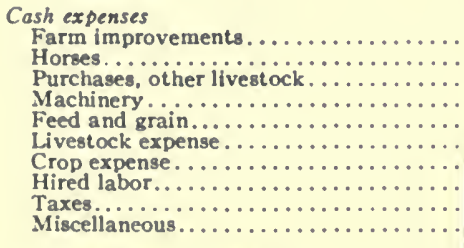 & $\begin{array}{r}\$ 109 \\
29 \\
289 \\
304 \\
393 \\
11 \\
159 \\
57 \\
143 \\
22\end{array}$ & $\begin{array}{r}\$ 109 \\
13 \\
171 \\
311 \\
380 \\
7 \\
102 \\
121 \\
136 \\
20\end{array}$ & $\begin{array}{r}\$ 104 \\
8 \\
139 \\
307 \\
485 \\
25 \\
151 \\
114 \\
172 \\
27\end{array}$ & $\begin{array}{r}\$ 63 \\
33 \\
68 \\
211 \\
150 \\
10 \\
111 \\
103 \\
122 \\
21\end{array}$ & $\begin{array}{r}\$ 56 \\
31 \\
140 \\
172 \\
105 \\
20 \\
60 \\
62 \\
120 \\
18\end{array}$ & $\begin{array}{r}\$ 88 \\
23 \\
161 \\
261 \\
302 \\
15 \\
117 \\
91 \\
139 \\
22\end{array}$ \\
\hline Total cash expenses............. & $\$ 1516$ & $\$ 1370$ & $\$ 1532$ & $\$ 892$ & $\$ 784$ & $\$ 1219$ \\
\hline Cash receipts less cash expense. . & $\$ 822$ & $\$ 891$ & $\$ 969$ & $\$ 728$ & $\$ 656$ & $\$ 813$ \\
\hline
\end{tabular}

tions in inventory values were not apparent until products were sold at a later date.

When farm incomes are expressed on a basis of cash receipts and expenses, only a partial picture of the farm's earnings is given, since no provision is made for the unpaid labor of the operator and his 
family and all changes in inventory.values are disregarded. Yet such a presentation for the period 1928-1932 serves to emphasize the adjustments made. The figures for receipts and expenses are gross, and are larger, therefore, than the corresponding net figures given in Table 36.

When expressed on a cash basis some items of income have a tendency to carry over into the succeeding year, since returns on one year's production of crops or livestock are frequently not realized as sales until after the beginning of the next calendar year. This is illustrated by the high returns for 1930, the severe drouth year, in which crop production was severely affected. The resulting shortage of feeds during the latter half of that year probably caused the marketing of some livestock which would otherwise have been held. Total cash receipts showed a marked reduction in 1931, with still further reductions in 1932.

As receipts decreased, cash expenses were reduced in even greater degree. For this reason the excess of cash receipts above operating expenses declined less than either the cash receipts or cash expenses. The total amount above cash operating expenses, however, averaged less than $\$ 1,000$ annually per farm during each year of this period. Considering both the small cash expenses and the low margin above them available for all personal and family requirements and for payments on debts, it is obvious that there has been need of increased gross receipts from these farms.

\section{How Redtop Has Been Used on Selected Farms}

The place that redtop may generally fill in the organization of farms in this territory may be illustrated by the situation on three individual farms during the four-year period 1929-1932 (Table 37). These farms had approximately the same land value per acre and about the same investment in livestock in relation to acreage. Farm $A$ represents an over-emphasis on redtop on a small farm, while Farms $B$ and $C$ show good use of the crop on a large farm and on an averagesized farm.

Farm A, the smallest of the three farms, consists of 126 acres of tillable land of which 66 acres, or 54.5 percent, of the tillable area was in redtop. Of this area, 26 acres were harvested for seed and gave an average yield of 43 pounds an acre; 11 acres were cut for hay, and 29 acres were pastured. Sales of redtop seed made up 91.5 percent of the crop sales. The only legume grown was soybeans, which occupied an average of 17 acres each year. Yearly gross re- 
turns an acre averaged \$4.42, of which livestock and livestock products made up 75.5 percent. Eggs, dairy products, and cattle were the more important sources of livestock income. This farm had 6

Table 37. Organization of Three Farms in the Redtop District of ILLINOIS, AVERAGE FOR 1929-1932

\begin{tabular}{|c|c|c|c|}
\hline Item & Farm A & Farm B & Farm C \\
\hline 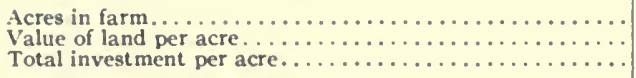 & $\begin{array}{r}126 \\
\$ 23.75 \\
43.00\end{array}$ & $\begin{array}{c}400 \\
\$ 25.88 \\
39.15\end{array}$ & $\begin{aligned} 210 \\
\$ 23.57 \\
48.37\end{aligned}$ \\
\hline 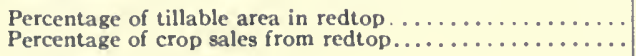 & $\begin{array}{l}54.5 \\
91.5\end{array}$ & $\begin{array}{l}42.5 \\
51.3\end{array}$ & $\begin{array}{l}19.1 \\
36.4\end{array}$ \\
\hline 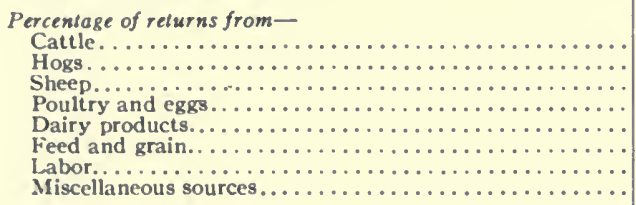 & $\begin{array}{r}18.0 \\
5.1 \\
29.3 \\
23.2 \\
15.8 \\
7.2 \\
1.4\end{array}$ & $\begin{array}{r}7.2 \\
39.8 \\
6.6 \\
11.5 \\
16.6 \\
8.2 \\
9.0 \\
1.1\end{array}$ & $\begin{array}{r}7.5 \\
32.3 \\
21.9 \\
8.2 \\
29.2 \\
.5 \\
.4\end{array}$ \\
\hline 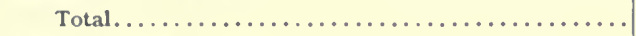 & 100.0 & 100.0 & 100.0 \\
\hline 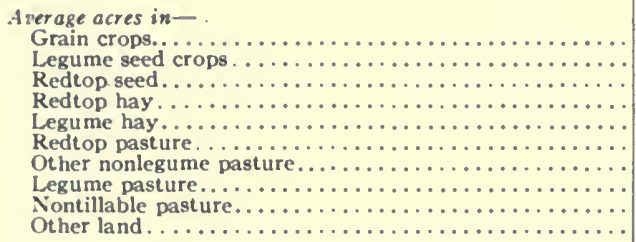 & $\begin{array}{r}32 \\
1 \\
26 \\
11 \\
17 \\
29 \\
5 \\
\cdots \\
3\end{array}$ & $\begin{array}{r}104 \\
109 \\
5 \\
41 \\
54 \\
81 \\
\cdots \\
\because 6\end{array}$ & $\begin{array}{r}81 \\
3 \\
28 \\
2 \\
13 \\
19 \\
19 \\
11 \\
21 \\
32\end{array}$ \\
\hline 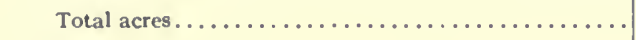 & 126 & 400 & 210 \\
\hline 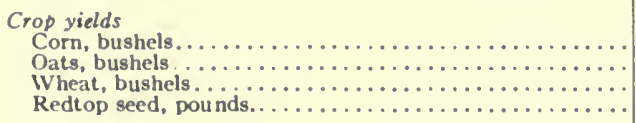 & $\begin{array}{l}14.7 \\
18.0 \\
42.8\end{array}$ & $\begin{array}{l}24.0 \\
17.0 \\
15.1 \\
30.2\end{array}$ & $\begin{array}{l}29.4 \\
29.5 \\
21.4 \\
77.1\end{array}$ \\
\hline 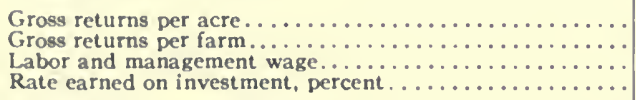 & $\begin{array}{l}\$ 4.42 \\
\$ 556 \\
\$-287 \\
-10.0\end{array}$ & $\begin{array}{l}\$ 2.90 \\
\$ 50 \\
\$ 8 \\
2.2\end{array}$ & $\begin{array}{c}\$ 9.25 \\
\$ 1 \\
\$ 170 \\
3.3\end{array}$ \\
\hline $\begin{array}{l}\text { Investment in livestock per acre } \ldots \ldots \ldots \ldots \ldots \ldots \ldots \ldots \\
\text { Returns from livestock per acre } \ldots \ldots \ldots \ldots \ldots \ldots \ldots \\
\text { Returns per } \$ 100 \text { invested in livestock } \ldots \ldots \ldots \ldots \ldots\end{array}$ & $\begin{array}{r}\$ 4.60 \\
\$ 3.00 \\
\$ 65.00\end{array}$ & $\begin{array}{r}\$ 4.10 \\
\$ 4.75 \\
\$ 116.00\end{array}$ & $\begin{array}{r}\$ 4.20 \\
\$ 6.45 \\
\$ 153.00\end{array}$ \\
\hline
\end{tabular}

cows, 1 sow, and 164 hens for the average of the period. Gross returns, net earnings, crop yields, and efficiency of livestock were all low.

While many circumstances may contribute to these results, it is evident that on this small farm too large a proportion of the acreage was in redtop, an extensive type of crop, and insufficient legumes were grown to maintain soil fertility or to provide the most desirable combination of feed crops. 
Farm $B$ was a large unit of 400 acres, of which 168 acres, or 42.5 percent, of the tillable area was in redtop. Redtop seed was harvested from an average of 109 acres, hay was cut from 5 acres, and 54 acres were used for pasture. Redtop accounted for 51.3 percent of crop sales. Gross returns amounted to $\$ 5.90$ an acre, of which 81.7 percent was from livestock sources. Hogs accounted for two-fifths of the total returns, and substantial amounts were received from dairy sales and poultry. This farm had an average of 14 cows, 5 sows, 38 sheep, and 179 hens. As compared with Farm $A$, yields of corn were higher and those of redtop seed lower. The relatively low yields of redtop seed resulted partly from renting some lower-value seed land, which was handled apart from the regular cropping plan. An average of 41 acres of soybeans was grown, all of which was harvested for hay.

Gross returns and net earnings on Farm $B$ were much above the average for the farms of the district and the acre-returns from livestock exceeded those on Farm A. On Farm $B$ the acreage in grain and legume crops was equal to the average total crop acreage on farms of the district; and the redtop seed and hay acreage was additional. Bluegrass and timothy furnished the major part and redtop a little more than one-fourth of the pasture area. In one year 64 acres of annual pasture was seeded.

Farm $C$ consisted of 210 acres, about the average for the farms keeping records. Twenty acres were nontillable pasture. This farm had 30 acres, or 19.1 percent of the tillable area, in redtop; of this, 28 acres were harvested for seed and 2 acres for hay. Alsike clover, red clover, and soybeans were grown for hay or pasture. Yields of grain crops and of redtop seed were much higher than on Farms $A$ and $B$, reflecting the effects of a fertility program. An average of 7 cows, 3 sows, and 214 hens was kept. While the returns an acre from livestock exceeded those from the other farms, there was also a considerable income from crop sales. Gross receipts amounted to $\$ 9.25$ an acre, of which 69.9 percent was from livestock sources and 29.2 percent from crops. Returns from redtop sales exceeded those from either Farm A or Farm B, altho they represented a much smaller proportion of crop receipts. Returns from livestock in relation to the capital invested were more than double those of Farm $A$ and one-third more than on Farm B.

The above differences are a result of differences in management. The results on these three farms indicate that redtop can be included as a profitable crop on well-organized and efficiently operated farms in this district. 


\section{EFFECT OF CASH-OUTLAY REQUIREMENTS ON USE OF REDTOP}

Comparison of the expenses in harvesting and marketing redtop with the cash returns from crop (Table 38 ) emphasizes the advantage of including redtop in a carefully developed plan for the entire farm rather than as an independent cash crop.

The actual cash outlay for binding, threshing, and delivering the redtop seed crop to market in 1931 and 1932 and the return from seed is shown by counties in Table 38. Tho custom rates of harvesting, threshing, and marketing declined somewhat in the redtop district in

Table 38.-Cash Expenditures for Harvesting and Marketing Redtop in 14 SOUtherN Illinois Counties, 1931 AND 1932

\begin{tabular}{l|l|l|c|c|c|c|c|c|c|c}
\hline \hline County & $\begin{array}{l}\text { Num- } \\
\text { ber of } \\
\text { farms }\end{array}$ & $\begin{array}{c}\text { Acres } \\
\text { seed } \\
\text { per } \\
\text { farm }\end{array}$ & $\begin{array}{c}\text { Prod. } \\
\text { per } \\
\text { farm } \\
\text { (lbs.) }\end{array}$ & $\begin{array}{c}\text { Binding } \\
\text { costs }\end{array}$ & $\begin{array}{c}\text { Thresh- } \\
\text { ing } \\
\text { costs }\end{array}$ & $\begin{array}{c}\text { Deliv- } \\
\text { ery } \\
\text { costs }\end{array}$ & $\begin{array}{c}\text { Total } \\
\text { cost }\end{array}$ & $\begin{array}{c}\text { Return } \\
\text { from } \\
\text { seed }\end{array}$ & $\begin{array}{c}\text { Net } \\
\text { per } \\
\text { acre }\end{array}$ & $\begin{array}{c}\text { Miles } \\
\text { Lo } \\
\text { market }\end{array}$ \\
\hline
\end{tabular}

1931

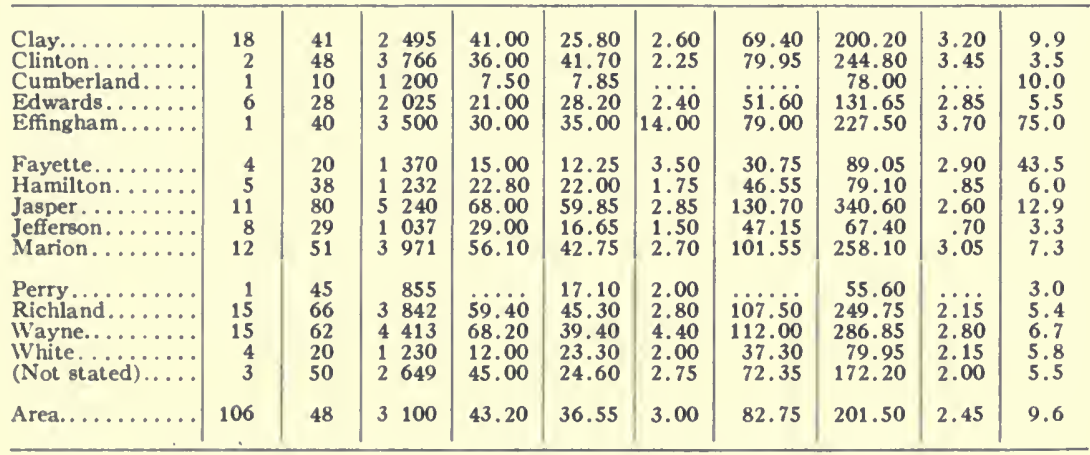

1932

\begin{tabular}{|c|c|c|c|c|c|c|c|c|c|c|}
\hline Clay.... & 18 & 42 & 2670 & 34.70 & 21.95 & 2.15 & 57.80 & 93.45 & .85 & 8.4 \\
\hline Clinton ......... & 2 & 48 & & $\cdots \cdots$ & $\ldots \ldots$ & $\cdots$ & $\ldots \ldots$ & & $\ldots$. & 6.0 \\
\hline Cumberland..... & 1 & 10 & 1200 & 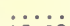 & - & & $\ldots \ldots$ & 42.00 & & \\
\hline Edwards......... & 6 & 28 & 1599 & 18.20 & 17.10 & 1.10 & 36.40 & 55.95 & .70 & 5.9 \\
\hline Effingham....... & 1 & 40 & 3500 & 30.00 & 30.00 & 8.00 & 68.00 & 122.50 & 1.35 & 75.0 \\
\hline Fayette. & 4 & 23 & 1572 & 15.75 & 12.90 & 3.50 & 32.15 & 55.00 & 1.00 & 43.5 \\
\hline Hamiltor & 5 & 22 & 210 & & 2.25 & & & 7.35 & & 1.0 \\
\hline Jasper........ & 11 & 73 & 5337 & 58.40 & 56.75 & 3.00 & 118.15 & 186.80 & .95 & 13.8 \\
\hline Jefferson.... & 8 & 24 & 1206 & 24.00 & 13.05 & 1.00 & 38.05 & 42.20 & .15 & 2.8 \\
\hline Marion.......... & 12 & 31 & 2957 & 29.45 & 26.40 & 1.90 & 57.75 & 103.40 & 1.45 & 8.2 \\
\hline Perry & 1 & 30 & & & & & & & & \\
\hline Richland........ & 15 & 58 & 3709 & 46.40 & 34.45 & 2.75 & 83.55 & 129.80 & .80 & 5.6 \\
\hline Wayne.......... & 15 & 49 & 3045 & 39.20 & 21.75 & 2.95 & 63.90 & 116.60 & 1.05 & 5.7 \\
\hline White...... & 4 & 12 & 307 & 5.40 & 3.30 & 2.00 & 10.70 & 10.75 & 0 & 5.8 \\
\hline (Not stated)..... & 3 & 40 & 4920 & 36.00 & 38.95 & 3.00 & 77.95 & 172.20 & 2.35 & 5.5 \\
\hline Area........... & 106 & 42 & 2910 & 33.60 & 26.00 & 2.50 & 62.10 & 101.85 & .95 & 10.4 \\
\hline
\end{tabular}

* On the basis of 6.5 cents per pound in 1931 and 3.5 cents per pound in 1932. 
1932 from those of $1931,{ }^{a}$ they were still so high in relation to prices that they absorbed nearly all the receipts. At a price of 6.5 cents a pound in 1931, the returns for seed above harvesting and marketing costs were less than $\$ 120$ a farm for the 48 acres of redtop which these farms averaged.

Marketing costs for the entire crop based on custom charges varied according to size of crop and distance to market. Some farmers took their seed direct to the pool warehouse; in many localities the pool had local arrangements for receiving the seed.

In spite of the small margin between harvesting costs and cash returns, dependence upon redtop as a cash crop is encouraged by the nature of the crop and by practices in the district. Since redtop occupies the land for several years, it offers a ready means of shifting between pasture, hay, and seed uses from year to year. The practice, however, of renting redtop fields for cash for the year, and the difficulties in undertaking soil-building programs in a period of unfavorable economic conditions, such as that from 1930 to 1934, have tended to perpetuate the widespread use of the crop on the farms of the district.

Under such conditions the producer's decision as to the use he will make of redtop is likely to depend upon the method which offers the widest margin between cash receipts and direct cash outlays, irrespective of the amount of labor, power, and other items supplied by the farm. The cash items of expense in harvesting and marketing redtop seed, measured in comparison with probable yields and prices, are all too frequently the criterion upon which the use of redtop is determined.

\section{PLACE OF REDTOP IN FUTURE ADJUSTMENTS OF SOUTHERN ILLINOIS AGRICULTURE}

\section{Size of Farm and Volume of Business as Factors in Adjustment}

On southern Illinois farms of small or intermediate size on which a considerable proportion of the tillable area is devoted to an extensive crop like redtop and on which the limited production of feed re-

"The average rate for cutting redtop with a binder decreased from 90 cents an acre in 1931 to 80 cents an acre in 1932 . The rate in 1931 varied from 60 cents in White county to $\$ 1.10$ in Wayne and Marion counties; the rate in 1932 varied from 45 cents in White county to $\$ 1.00$ in Jefferson. Average threshing charges decreased from 16.5 cents a bushel in 1931, the rate varying from 9 cents in Cumberland county to 28 in Perry, to 12.5 cents a bushel in 1932, the rate varying from 10 cents in Wayne county to 21 cents in Perry. The higher rates represent charges for threshing redtop which was mowed instead of bound. 
stricts livestock enterprises, returns are likely to be too limited to provide an adequate standard of living for the farm family (see Table 37, page 289).

On larger farms, however, a plan for farm improvement may be developed in two parts. First, a limited acreage could be improved by soil treatment and by adopting a suitable rotation of crops, including legumes. Second, redtop as an extensive crop might occupy a considerable proportion of the acreage of these farms. Such a twofold plan would work best on farms where the area used intensively would provide most of the feed crops and a fair volume of business. The land in redtop would then be used to enlarge the business, to utilize available labor, power and equipment, and to furnish a cash return, or to supply feed reserves in years of unfavorable crop production. With farms of intermediate size part or all of the redtop acreage could be used for pasture when desired, thus contributing directly to the feed supply rather than to the cash returns.

\section{Redtop Used to Best Advantage With Livestock}

The experience of farmers in the redtop district, as shown by the foregoing analyses of farm records, indicates a marked reliance upon livestock and livestock products as sources of farm returns. In view of these conditions and the limited volume and limited value of redtop production per acre, an increase in the acreage devoted to redtop would not usually increase the farm returns.

An increase in the yields of seed or of hay on the present acreage, however, would improve the position of the individual farm unless the cost of securing larger yields exceeded the value of the increase, or unless an increase in the total production resulted in lowered prices. While redtop makes its best yields on the better land, such land is generally used for other crops, commonly classed as higher-return crops, altho a year or more of high seed prices draws some of the better land into the production of redtop seed.

Redtop does best in connection with a livestock system of farming inasmuch as acre-yields of redtop seed are improved following pasturing. The use of a considerably larger part of the acreage for pasture and the rotation of the pasture and seed acreage would serve to increase the profitableness of that part harvested for seed and at the same time reduce the total seed supply, thus making for better seed prices.

Since the present redtop district is barely self-sufficient in feed supplies and since it is seldom possible to ship in feeds at favorable 
feed-livestock ratios, a further expansion of livestock numbers would appear to depend upon increasing the feed production of the district. A sound cropping plan would therefore offer a means of increasing the supply of crops both for feed and market.

\section{Soil-Improvement Programs Needed on Redtop Farms}

Definite data are not available regarding the extent to which limestone had been applied on the farms in the redtop district from which financial records were secured. Presumably limestone had not been applied on many of them, for fewer than half these farms grew legumes that usually require sweet soil and on many the acreages of such legumes were small. The limited returns on farms in the redtop territory for the period 1928-1932, moreover, indicate that a general liming program would have been difficult because of the lack of available funds.

Improvement in farming in this district may be effected by increasing the acreage of legumes grown, since legumes make possible increased yields of all crops and provide better balanced feeds for livestock. That this condition is recognized by farmers is indicated by the increasing use of legume hays and pastures. During the five years 1928-1932 legumes made up 69 percent of the hay acreage on farms keeping records in the central or seed area and 58.5 percent on those in the border or hay and pasture area. Soybeans and cowpeas comprized the major part of this acreage. These crops are poorly suited to pasture uses, and only 14 and 13 percent respectively of the tillable pasture area was in legumes. The need for an acid-tolerant legume pasture crop is evident. Lespedeza holds promise of filling this need.

\section{Economic Limitations on Redtop Acreage}

In view of the tendency for several years past for annual redtop seed production to exceed demand and for storage stocks to accumulate, the possibility of securing prices for redtop seed which would yield remunerative returns must depend upon an increase in demand or a curtailed production.

The individual farmer's best opportunity to adjust his farming operations to the changed demand for redtop lies in so improving the farm plan that a part of the redtop seed acreage may be used for hay and pasture on the farm in connection with livestock production, and so that the acreage cut for seed may be varied in response to market demands. 


\section{SUMMARY}

1. Redtop is the second most important pasture grass in the United States, ranking next to Kentucky bluegrass. About 85 percent of the world's supply of redtop seed and 95 percent of the total redtop seed in the United States is produced in a dozen counties in southern Illinois. (p. 231)

2. The principal uses of redtop are as (1) a wet-land or sour-land hay crop, (2) a part of pasture mixtures, (3) a part of lawn and golfcourse mixtures, (4) a soil binder, and (5) an ingredient in seed mixtures for hay to be used on the farm. No other cultivated grass will grow under so wide a range of conditions of soil and climate as will redtop. (p. 232)

3. At Newton and Odin experiment fields in southern Illinois organic manure and lime gave yields considerably higher than the average for the redtop area. (p. 233)

4. Redtop gives best results when planted on a well-prepared compact seed bed and is usually sown broadcast in the fall. (p. 235)

5. Under normal conditions redtop should be harvested for seed not later than one week after blooming is completed, because of the danger of loss thru shattering if harvesting is delayed beyond that time. (p. 241)

6. The annual acreage of redtop harvested for seed averaged 204,800 acres for the period 1922-1933. The average yield of seed for this period was 54 pounds an acre. (p. 244)

7. A total of more than 160,000 tons of redtop straw was available from the 1931 crop. Redtop straw has not been given much market consideration in recent years, commercial outlet for it having largely disappeared. (p. 248)

8. On the basis of each acre of redtop meadow supplying 25 pasture-days per animal unit and of each acre of redtop pasture supplying 60 pasture-days, a total yearly acreage sufficient to carry 225,000 animals for 200 days has been estimated for the state on the basis of 1929 production. (p. 251)

9. Commercial movements of redtop hay have been restricted in recent years almost entirely to local purchases. It is not uncommon to see farm stacks of hay two and three years old. (p. 252)

10. Most of the redtop seed has been utilized in the eastern half of the United States north of the southern line of Tennessee. Various uses for redtop seed may be ranked in importance as follows: 
lawn-grass mixtures, (2) pasture mixtures, (3) golf-course mixtures, (4) meadows, (5) binding terraces and roadsides, and preventing erosion. (p. 255)

11. The annual production and consumption of Kentucky bluegrass seed and redtop seed have been practically equal. Both are important constituents of lawn-grass mixtures. On poorer soils, rather acid soils, wet soils, and on other soils if seeded late in the season, the proportion of redtop in such mixtures should be between 20 and 40 percent. (pp. 256-257)

12. Redtop seed consumption may be expected to show further increase. (p. 257)

13. Seed is sold to local dealers on a cleaned 90-percent basis, which is arrived at by cleaning a measured quantity of seed on small fanning mills. Redtop seed as it comes on the market is relatively pure and free from noxious weed seeds. (pp. 258-260)

14. As a result of interviews with all the important local seed dealers in Illinois between September 8 and 15, 1932, it is estimated that about 17.5 percent of the crop of the previous year was carried over by local handlers. (pp. 260-261)

15. The amount of seed handled by the Egyptian Seed Growers' Exchange represents an important proportion of the entire redtop seed supply of the state. The Redtop Growers' Warehouse Association, a subsidiary organization of the Seed Exchange, owns and operates a government-bonded warehouse which receives seed as delivered for the account of the producer. (pp. 261-262)

16. Wholesale dealers handle redtop along with other seed and dispose of the bulk of it in grass-seed mixtures, altho a considerable amount is sold as straight redtop seed for use in southern states. ( $p$. 262)

17. Retail sales of redtop seed are made both in mixture and in bulk. In areas in which redtop is grown alone to a considerable extent, the proportion of redtop seed sold in bulk is high. (p. 263)

18. Demands for systematic methods of establishing and maintaining balance between production and consumption of redtop seed reached concrete expression in a proposed marketing agreement for the redtop seed industry on which hearings were held March 9, 1934. (p. 264)

19. Prices of recleaned redtop seed reached a low of 3.4 cents a pound in 1932, and during four years of the period 1907-1932 reached 
annual averages as high as 22 cents. The average price for 1923-1932 was about 13 cents. (p. 26.5)

20. The spread between producer and wholesale prices of redtop seed was 3.6 cents a pound, and between wholesale and retail prices, 3.7 cents, during the ten-year period 1923-1932. (p. 268)

21. Import duties have been levied on redtop seed since 1922. These were increased sufficiently in 1930 to provide an embargo against importation. The duties on all hays have been such as to exclude competition in domestic markets. (p. 271)

22. General organization and financial returns from record-keeping farms in the seed and hay areas of the redtop district have been similar. (p. 272)

23. The small proportion of farm receipts from crops in the central or seed area of the redtop district and the large part from livestock and livestock products indicates that most of the crops grown have been utilized on the farm. (p. 279)

24. Soybeans and cowpeas do not compete directly with redtop from the labor standpoint, inasmuch as their planting comes ahead of redtop harvest and their harvest time much later. In their utilization on the farm, however, they displace much redtop hay or straw. (p. 283)

25. In comparison with the central, or redtop seed, area the farm investment in the border, or hay and pasture, area showed somewhat more hogs and poultry and fewer cattle and sheep. (p. 285)

26. A detailed study of three farms in the redtop district, representing wide differences in conditions, indicates that redtop can be included as a profitable crop on well-organized and efficiently operated farms in this district. (pp. 288-290)

27. Redtop does best in connection with livestock systems of farming. Acre-yields of redtop seed are improved following pasturing. (p. 293)

28. Improvement in farming in the redtop district may be effected by increasing the acreage of legumes, since legumes make possible increased yields of all crops and provide better balanced feeds for livestock. (p. 294)

29. The individual farmer's best opportunity to adjust his farming operations to the changed demand for redtop lies in so improving the farm plan that a part of the redtop seed acreage may be used for hay and pasture on the farm in livestock production, and so that the acreage cut for seed may be varied in response to market demands. (p. 294) 


\section{LITERATURE CITED}

1. Buzzard, R. G. The red-top production of southeastern Illinois. Ill. State Acad. Sci. Trans. 23, No. 3, 465-475. 1931.

2. Dulaney, B. W. How redtop was introduced into Illinois. Seed Trade News 15, No. 21, 10. 1930.

3. Ill. Coop. Crop Reptg. Serv. Circ. 396, 91-92. 1930.

4. Lамв, Јонм. Some factors affecting production of redtop seed in southern

Illinois. Master's thesis in Agronomy, unpublished, Univ. of Ill. 1929.

5. Mosher, Enna. The grasses of Illinois. Ill. Agr. Exp. Sta. Bul. 205. 1918.

6. Pieper, J. J., and Burlison, W. L. Redtop seed production in Illinois. Bul. U. S. Golf Assn. Green Sec. 10, No. 12, 225-228. 1930.

7. Piper, C. V. Important cultivated grasses. U. S. Dept. Agr. Bul. 1254. 1922.

8. - Forage plants and their culture. p. 192. MacMillan. 1924.

9. and others. Our forage resources. U. S. Dept. Agr. Yearbook, 357-380. 1923.

10. Rauchenstein, Emil, and Ross, R. C. Cost of producing field crops in three areas of Illinois, 1913-1922. Ill. Agr. Exp. Sta. Bul. 277. 1926.

11. Smith, R. S., and Norton, E. A. Certain profiles in southern Illinois. Jour. Amer. Soc. Agron. 19, 324-332. 1927.

12. Stewart, C. L. Farm real estate valuations in Illinois with special reference to township averages. Ill. Agr. Exp. Sta. Bul. 399. 1934.

13. U. S. Depr. Agr., Bur. Agr. Econ., Div. Hay, Feed, and Seed. Report, 1932.

14. U. S. Dept. Agr., Div. Prod. Forage Crops and Replacement Crops Sec., A. A. A. Pasture plants and pasture mixtures suggested for seeding on the acreage taken out of cotton, tobacco, wheat, and corn. Mimeo. pub. October 16, 1933.

15. Wilcox, W. W. Trends in the production and organization of farms in the redtop area of Illinois. Master's thesis in Farm Organization and Management, unpublished, Univ. of Ill. 1930.

\section{ACKNOWLEDGMENT}

Various state and federal agencies as well as private enterprises and individuals have given helpful information and assistance in connection with this study; namely, the Illinois Crop Reporting Service (a cooperative enterprise of the Illinois State Department of Agriculture and the U. S. Department of Agriculture), the Bureau of Agricultural Economics of the U. S. Department of Agriculture, the Bureau of the Census, practically all redtop cleaning establishments and other local handlers in Illinois, a number of wholesale dealers in Illinois and other states, and many producers in the Illinois redtop district.

For special assistance rendered the authors make acknowledgment to the following members of the staff of the Illinois Agricultural Experiment Station, L. J. Norton, Assistant Chief in Agricultural Economics, E. L. McBride, formerly Research Assistant in Agricultural Economics, and J. J. Pieper, Associate Chief in Crop Production; and to G. C. Edler, Bureau of Agricultural Economics, U. S. Department of Agriculture, and A. J. Surratt, Illinois Cooperative Crop Reporting Service. 


\section{SOURCES OF DATA}

(Tables for which no sources are here indicated are based on material gathered at the Illinois Agricultural Experiment Station and published here for the first time.)

Tables $2,5,8,9,11,12$. Information procured by field interviews by one of the authors and by Experiment Station questionnaires, fall, 1932. Both scries of records were well distributed over the important redtop seedproducing counties.

Table 7. U. S. Census, 1930. Agriculture 2, part 1. County tables 5 and 7, pages 599-607, 616-623.

Tables 10, 14, 15, 16, 18, 22. Seasonal reports issued by Bur. Agr. Econ. Hay, Feed, and Seed Div., U. S. Dept. Agr, 1923-1932.

Table 13. Seasonal reports issued by Illinois Cooperative Crop Reporting Service, 1919-1932.

Table 17. Hay, by Piper, C. V., and others. Agricultural Yearbook, USDA, p. 326. 1924.

Tables 19, 20, and 21. Secl statistics, by Louis B. Flohr. Statis. Bul. 2, USDA, 1924; Seasonal reports issued by Bur. Agr. Econ. Hay, Feed, and Secd Div., USDA, 1919-1933.

Table 23. Wholesale prices, 1931. Bur. Lahor Statis. Bul. 572, January, 1933; Wholesale prices, December and year 1932. 1933; Bur. Labor Statis. U. S. Dept. Labor: Seasonal reports issued by Bur. Agr. Econ. Hay, Feed, and Seed Div., USDA, 1919-1933.

Table 24. Tariff act of 1930, House Doc. 476, 71st Cong., 2d Sess., 1930: Comparison of tariff acts of 1909, 1913, 1922, by C. F. Moore, published by U. S. Cong. House Repr. Ways and Means Com.

Table 25. Ill. Agr. Exp. Sta. Bul. 277. From Table 1, page 44. Man labor, horse labor, seed, threshing, and interest rates were adjusted on the basis of an average of those prevailing for the 1931 and 1932 crops.

Tables 26 to 36 . Based on farm financial records kept by farmers in area indicated in cooperation with their county farm bureaus and the University of Illinois.

Fig. 1. From Agricultural Yearbook, USDA, p. 380. 1923. 



4

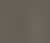



UNIVERSITY OF ILLINOIS-URBANA

0.630 .71468

BULLETIN. URBANA

400-408 1934

$\mathrm{COO2}$

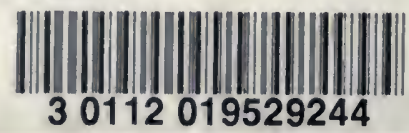

